\title{
Conversion Characteristics of 10 Selected Oil Shales
}

\section{Topical Report}

F.P. Miknis

August 1989

Work Performed Under Cooperative Agreement No.: DE-FC21-86MC11076

For

U.S. Departmert of Energy

Office of Fossil Energy

Morgantown Eruerg $`$ Technology Center

Morgantown, West Virginia

By

Westem Research Institute

Laramie, Wyoming 


\section{DISCLAIMER}

This report was prepared as an account of work sponsored by an agency of the United States Government. Neither the United States Government nor any agency thereof, nor any of their employees makes any warranty, express of irnplied, or assumes any legal liability or responsibility for the accuracy, completeness or usefulness of any information, apparatus, product, or process disclosed, or represents that its use would not infringe privately owned rights. Reference herein to any specific commercial product, process, or service by trade name, trademark, manufacturer, or otherwise, does not necessarily constitute or imply its endorsement, recommendation, or favoring by the United States Government or any agency thereof. The views and opinions of authors expressed herein do not necessarily state or reflect those of the United States Govemment or any agency thereof.

This report has been reproduced directly from the best available copy.

Available to DOE and DOE contractors from the Office of Scientific and Technical Information, P.O. Box 62, Oak Ridge, TN 37831; prices available from (615)576-8401, FTS 626-8401.

Available to the public from the National Technical Information Service, U.S. Department of Commerce, 5285 Port Royal Rd., Springfield, VA 22161. 


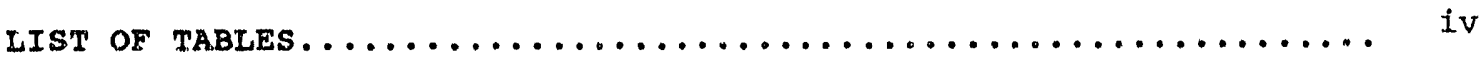

LIS'T OF FIGURES .............................. v

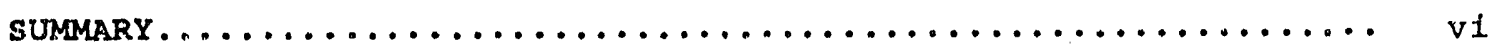

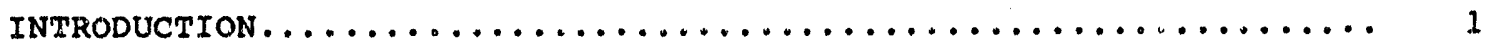

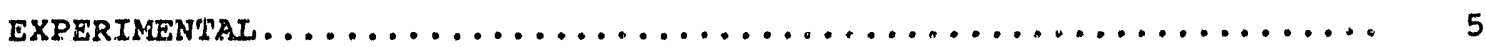

Material 3alance Fischer Assay.................... 5

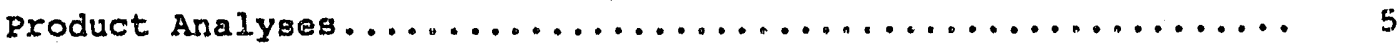

NMR Measurements.................................... 5

simulated Distillations.......................... 8

RESULTS AND DISCUSSION $\ldots \ldots \ldots \ldots \ldots \ldots \ldots \ldots \ldots \ldots \ldots \ldots \ldots \ldots \ldots \ldots$

SUMMARY AND CONCLUSIONS $\ldots \ldots \ldots \ldots \ldots \ldots \ldots \ldots \ldots \ldots \ldots \ldots \ldots, 22$

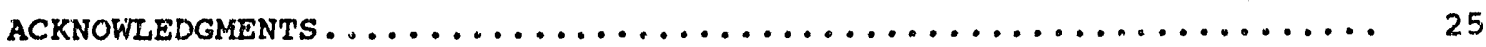

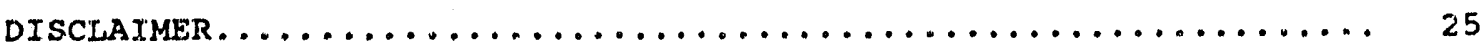

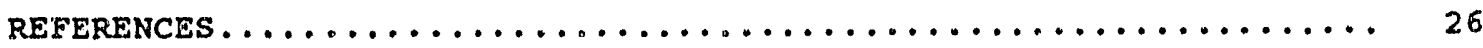

APPENDIX A. Fischer Assay Conversion Data.............. 27

ADPENDIX B. oil shale Data sheets..................... 32 
1. Summary of NMR Conversion Data for Ten selected oil

shales...................................... 15

A-1. Material Balance Fischer Assay Results for oil Shales....... 28

A-2. Material Balance Fischer Assay Gas Analyses.............. 29

A-3. Elemental Analyses, Aromaticities, Molecular Weights, and Specific Gravities of Material Balance Fischer Assay

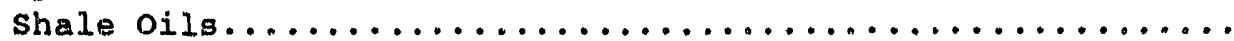

A-4. Simulated Distillation Fractions of Various Material Balance Fischer Assay shale oils........................ 
1. Schematic Illustrating a Fischer Assay Product Distribution................................ 2

2. Schematic Illustrating a Fischer Assay Based on Carbon..... 3

3. Schematic Illustrating a Carbon Balance Fischer Assay Combined with NMR Measurements.................... 4

4. Solid-state ${ }^{13}$ C NMR spectra of Raw and spent oil shales... 6

5. Solid-state ${ }^{13} \mathrm{C}$ NMR spectra of a Kentucky spent shale cllustrating Effects of lcid Washing on spectral Quality,

(a) without washing, (b) with acid washing............. 7

6. Fischer Assay oil Yields....................... 10

7. Carbon Conversion to Oij during Fischer Assay........... 11

8. Correlation between Aliphatic Carbon in kaw shale and Carbon in the Fischer Assay oil................... 12

9. Correlation between Raw Shale Aromatic carbon and Residue Axomatic Carbon........................ 13

10. Number of Raw Shale Aliphatic Carbong Aromatized during Fischer Assay............................. 16

11. Percent Decrease in Raw Shale Aliphatic Carbons during Fischer Assay............................ 17

12. Ratio of Aromatic carbon in Residue to Aromatic Carbon in $\operatorname{Raw}$ shale................................ 18

13. Percent of Raw shale Aliphatic Carbons in Residue........ 20

14. Shale oil Molecular Weights..................... 2 .

15. Temperature at which 5 ? wt of shale oil Distilla....... 23 
The conversion behavior of 10 oil shales from seven foreign and three domestic deposits has been studied by combining solid- and liguid-state NMR measurements with matexial balance Fischer assay conversion data. The extent of aromatization of aliphatic carbons was determined. Between zero and 428 of the raw shale aliphatic carbon formed aromatic carbon during Fischer assay. For three of the shales, there was more aromatic carbon in the residue after Fischer assay than in the raw shale. Between 10 and 208 of the raw shale aliphatic carbons ended up as aliphatic carbons on the spent shale. Good correlations were found between the raw shale aliphatic carbon and carbon in the oil and between the raw shale aromatic carbon and aromatic carbon on the spent shale. simulated distillations and molecular weight determinations were performed on the shale oils. Greater than 508 of the oil consisted of the atmosphexic and vacuum gas oil boiling fractions. 
Probably the single most important item of information about an oil ghale is its potential to produce oil during heating. The Fischer assay (American Society for Testing and Materials Method D-3904-80) is the traditional. method for determining the oil potential of an oil shale. In brief, the Fischer assay consists of heating a $100-g$ sample of minus $8-\mathrm{mesh}(2.38-\mathrm{mm})$ oil shale to $500^{\circ} \mathrm{C}\left(932^{\circ} \mathrm{F}\right)$ at $12^{\circ} \mathrm{C} / \mathrm{min}$ and maintaining this temperature for 40 minutes. The hydrocarbon vapors that distill from the shale sample condense to form a shale oil. This material is collected, its volume and weight recocded, and specific gravity determined. From these measurements the oil potential is reported in either weight percent or gallons of oil per ton of shale

The Fischer assay is strictly a specification test and, as such, does not provide any information about the quantity or quality of the organic matter (kerogen) in the shale (Figure 1). It is essentially a black box from which oil and gas products evolve from the application of heat. Thus, for example, if two oil shales yield 10 and 20 wt 8 oil by Fischer assay there is no way to determine whether this difference is due to differences in quantity (amount) or quality (carbon structure) of the kerogen in the two shales.

In a material balance Fischer assay the elemental composition is determined for the raw shale and the gas, oil, and spent shale products. Therefore, the assay data can be normalized to the basis of 100 carbon atoms, and the percentage of carbon converted to carbon in the products can be obtained (Figure 2). The percentage of organic carbon in the raw shale can be used as an indicator of the quantity of organic matter (kerogen) in raw shale. The conversion of kerogen to oil., gas, and residue products will basically be the same for any amount of kerogen, provided the quality, or structure, of the kerogen remains relatively constant. To a large extent this is true for Green River Formation oil shales (Smith 1961) and the Devonian/Mississippian oil shales from the eastern United states (Miknis and Smith 1984).

The importance of kerogen structure on the conversion behavior of oil shales becomes more apparent when the conversion behavior of oil shales from different deposits, geologic ages, and depositional environments are compared (Miknis et al. 1982a). This is illustrated in Figure 3 for a Green River formation oil shale from colorado and a New Albany oil shale from Kentucky. For the Colorado oil shale, 62 out of 100 carbon atoms are converted to oil, compared to only 35 for the Kentucky oil shale. clearly, the structure of the kerogen is an important factor in the conversion behavior of oil shales. However, it has only been during the last decade, because of the development of solid-state nuclear magnetic resonance (NMR) techniques, that the aliphatic/aromatic carbon distribution in oil shale kerogens can be measured.

The combined use of the material balance Fischer assay and solid... state MMR measurements makes it possible to study the effects of kerogen structure on the conversion behavior of oil shales. By 


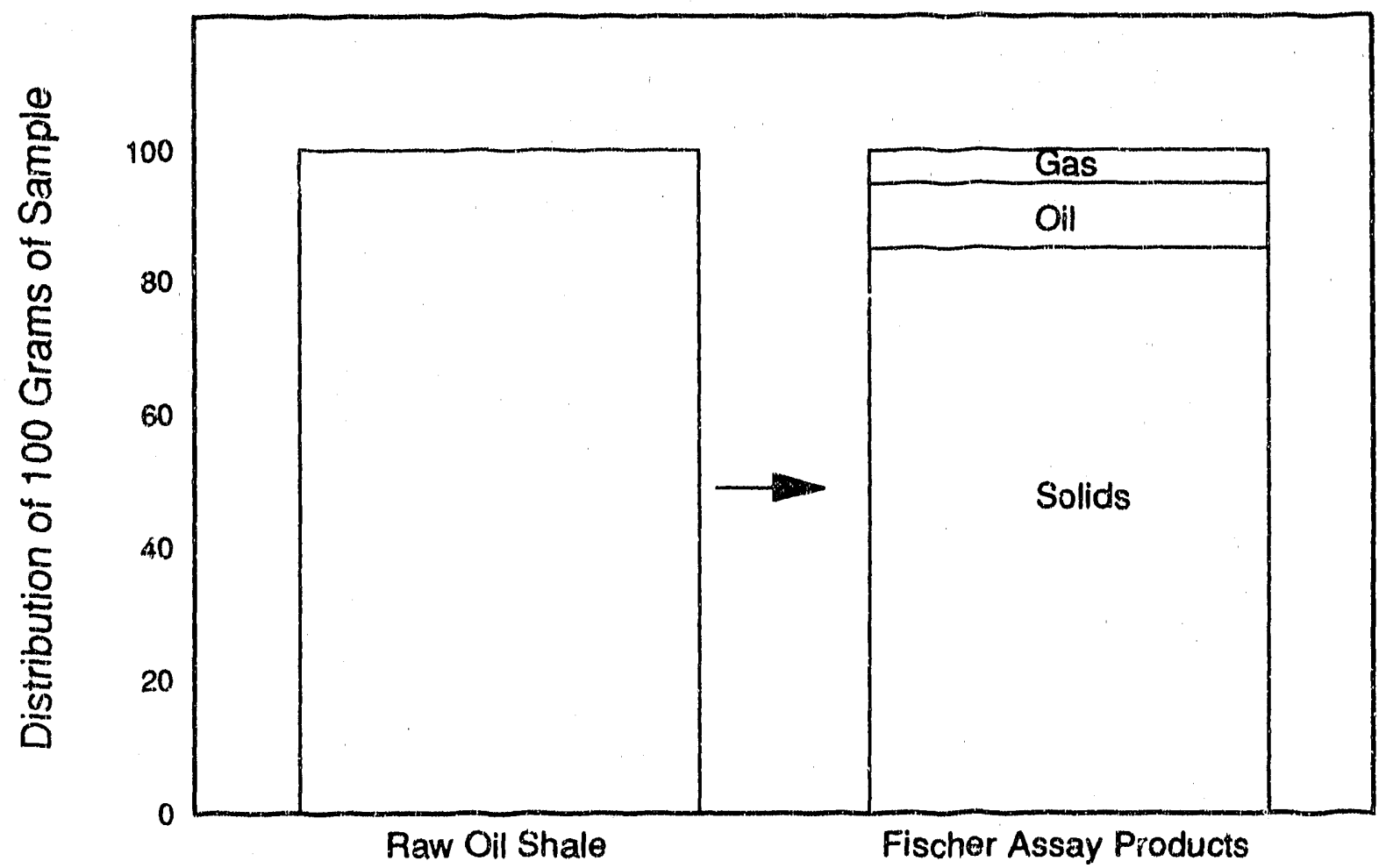

Figure 1. Schematic Illustrating Fischer Assay product Distribution 


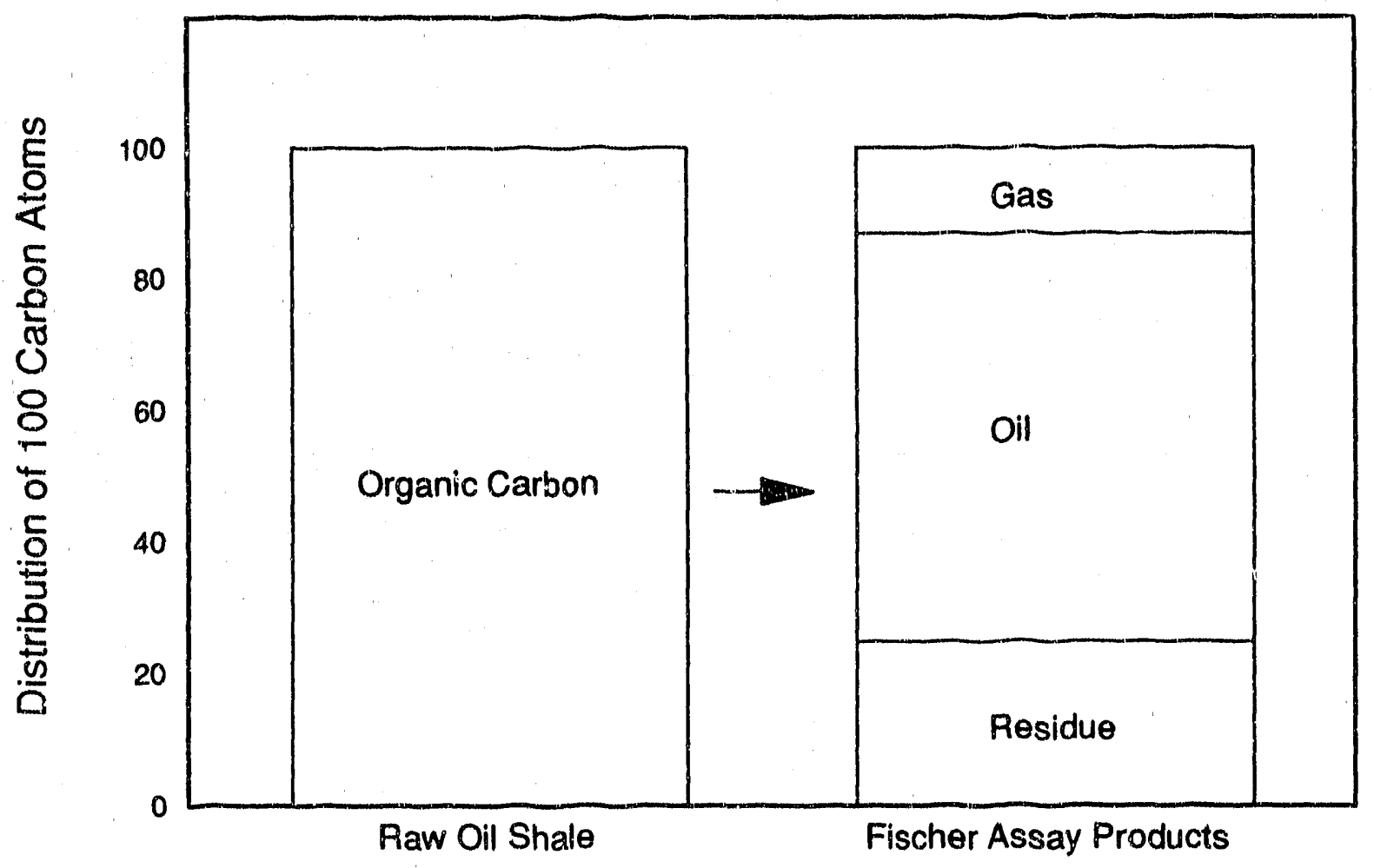

Figure 2. Schematic Illustrating Fischer Assay Baged on Carbon 


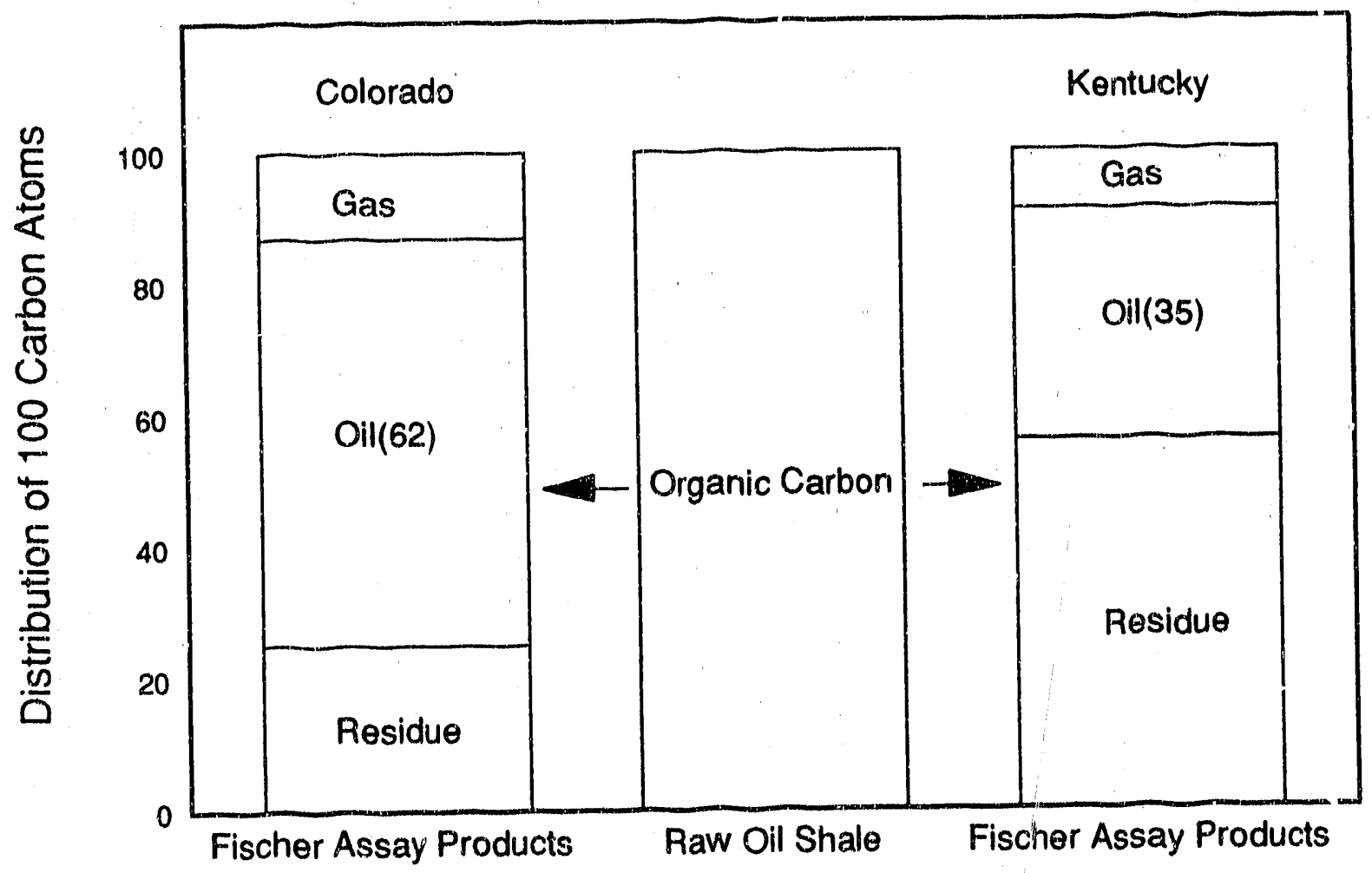

Figure 3. Schematic Illustrating a Carbon Balance Fischer Assay Combined with NMR Measurements 
including liquid-state NMR neasurements of the shale oils it becomes possible to do detailed carbon balances on the aromatic and aliphatic carbons during conversion. From these measurements, it is possible to determine how much aliphatic carbon aromatized during the standard Fischer assay.

The conversion behavior of 10 oil shales from seven foreign and three domestic deposits was studied by combining solid-and liquidstate NMR measurements with material balance rischer assay conversion data. Molecular weights and simulated distillations were determined for the shale oils to provide some additional information about the oils. The results of this study are the subject of this report.

\section{EXPERIMENTAL}

\section{Material Balance Fischer Assay}

Material balance Fischer assays were performed following a procedure developed at WRI. In this procedure, a 100-g sample of -65mesh (0.152-mm) particle size oil shale is heated in a stainless steel retort to $500^{\circ} \mathrm{C}\left(932^{\circ} \mathrm{F}\right)$ at $12^{\circ} \mathrm{C} / \mathrm{min}$ and maintained at this temperature for 40 minutes. Shale oil vapors are condensed at $0^{\circ} \mathrm{C}\left(32^{\circ} \mathrm{F}\right)$, añ noncondensible gases are drawn into an evacuated gas cylinder. The composition of the gas is determined by gas chromatography (GC). Material balance Fischer assal and carbon conversion results are reported in Table $\mathrm{A}-1$ of Appendix A. Gas compositions are reported in Table A-2.

\section{Product Analysem}

Elemental analyses (CHNs, mineral c) were obtained using standard ingtrumental methods. Carbon, hydrogen, and nitrogen were determined on a Perkin-Elmer $240 \mathrm{C}$ CHN analyzer; sulfur was determined using a Fisher Model 475 gufur analyzer; and mineral carbon was determined using a cuulometrics $\mathrm{CO}_{2}$ analyzer. Shale oil molecular weights were determined by vapor phase osmomedry (VPO) using toluene as the solvent. The results of the shale oil analyses are summarized in Table A- 3 .

\section{NMR Measurements}

Solid-state ${ }^{13} \mathrm{C}$ NMR techniques of cross polarization (CP) with magic-angle spinning (MAS) and high-power decoupling were used to measure the carbon digtributions in the raw and spent shales (Figure 4). These measurements were made at colorado state university. $\mathrm{CP} / \mathrm{MAs}$ spectra were acquired at a ${ }^{13} \mathrm{C}$ frequency of $15.1 \mathrm{MHz}$, a contact time of $1 \mathrm{~ms}$, and a pulse delay of $500 \mathrm{~ms}$. Typically, between 20,000 and 80,000 transients were recorded for the raw shales, depending upon organic content of the raw shale. For the spent shales, between 40,000 and 80,000 transients were recorded to obtain suitable CP/MAs spectra of tlese materials. However, in order to obtain these spectra the spent Ehales were washed with a $108 \mathrm{HCl}$ solution to remove paramagnetic impurities and improve the $s / \mathbb{N}$ ratio. An example of this is shown in Figure 5 for the Kentucky sunbury spent shale. Both spectra were 


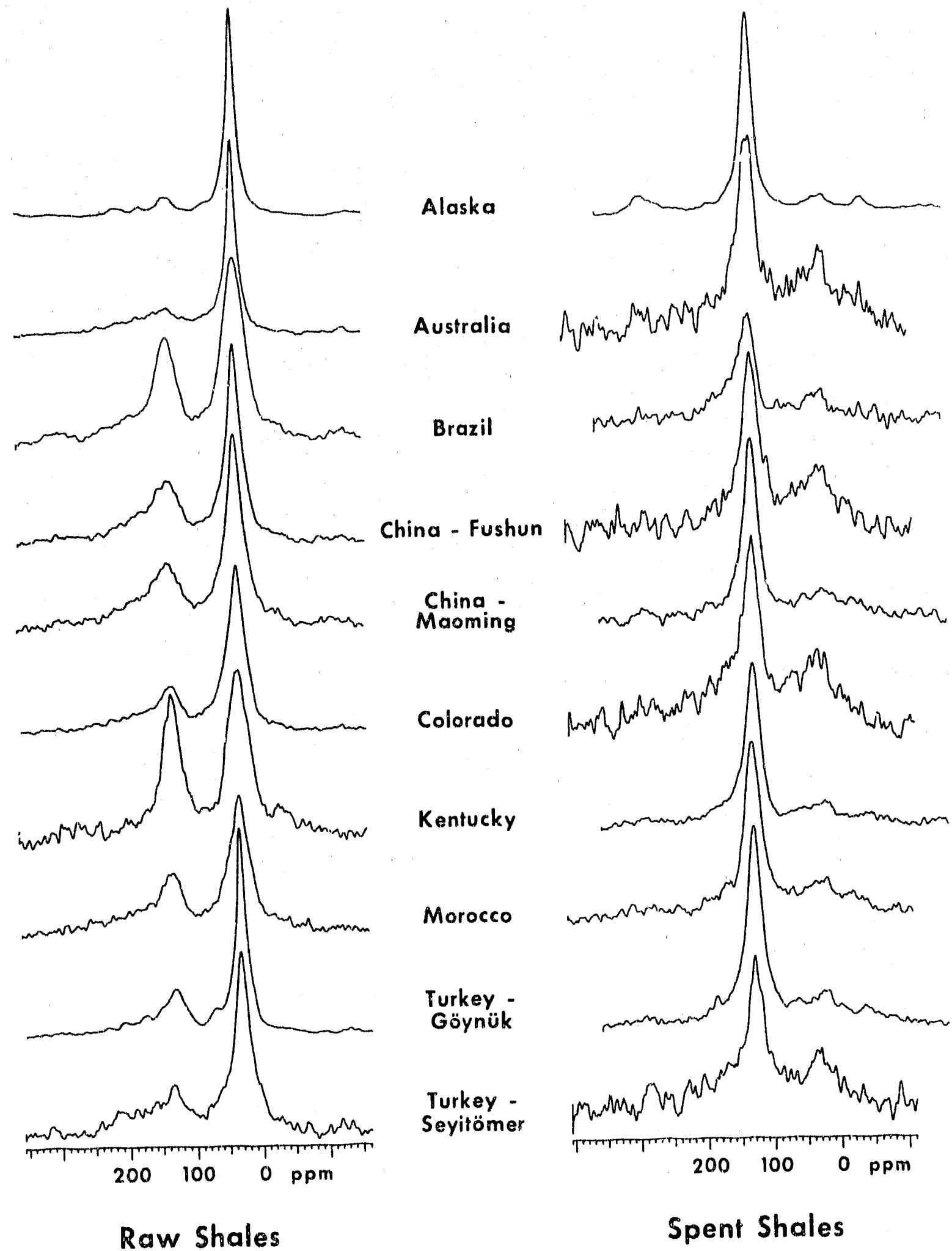

Figure 4. Solid-state ${ }^{13} \mathrm{C}$ NMR Spectra of Raw and spent oil shale 


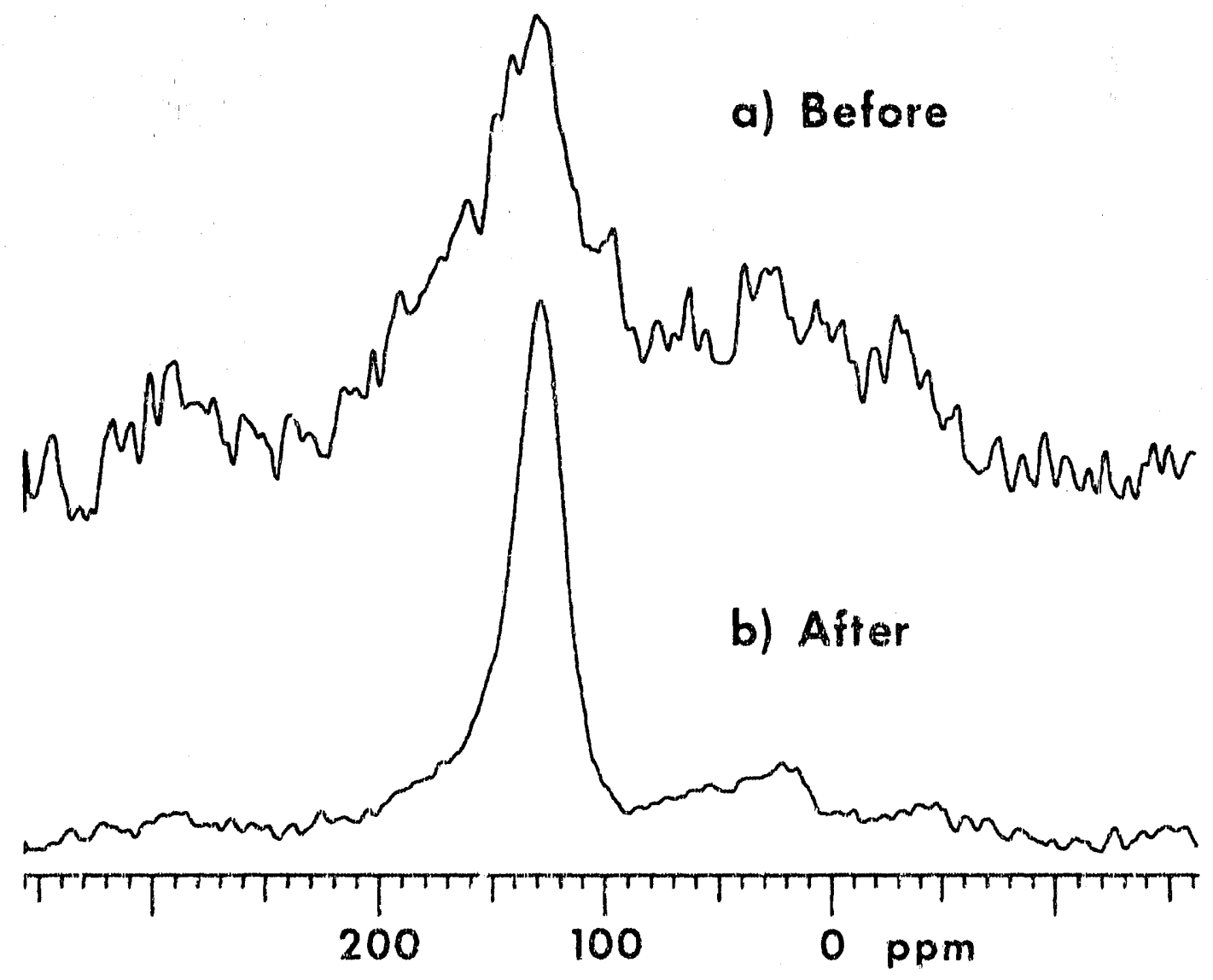

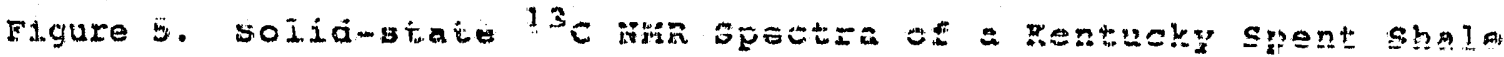
Illutrating Effects of Acid Washing on spectral Quality, (a) without washing, (b) with acid washing
} 
asquired under identical conditions. The improvement in resolution and $\mathrm{s} / \mathrm{N}$ from the acid wash is evident. However, for some shaies the improvel ent in $S / N$ is not as dramatic as for other spent shales (cf. the Alaskan and Australian spent shale spectra, Figure 1). The reasons for this are not known at this time.

The aromatic and aliphatic carbon fractions in the raw and spent shales were determined by integrating the signal intensity in the appropriate chemical shift region of the spectra. The region betureen 0 and $90 \mathrm{ppm}$ was chosen for the aliphatic carbons, and the region between 90 and $-210 \mathrm{ppm}$ was chosen for the apparent aromatic carbon region. This region alro includes contributions from carbonyl/carboxyl carbons (165 to $\sim 200 \mathrm{ppm}$ ). Generally, these carbon types are not well resolvable from the aromatic carbons and, thus, are included in the aromaticity values. Hence, the term apparent aromaticity is used to describe this spectral region. In order to better approximate the true aromatic carbon values, j.t was assumed that the $\mathrm{CO}_{2}$ and $\mathrm{cO}$ in the product gas originated from the carboxyl and carbonyl carbons in the $r$ aw shale and that no $\mathrm{CO}_{2}$ was liberated from carbonate decomposition. Therefore, the rumber of carbon atomo associated with the $\mathrm{CO}_{2}+\mathrm{CO}$ evolution was subtracted from the apparent carbon aromaticity. Also, spinning sidebands near 300 and $-40 \mathrm{ppm}$ due to aromatic carbons were added to the integrated aromatic carbon intensities. Figure 4 shows the CP/MAS ${ }^{13} \mathrm{C}$ NMR spectra of the raw and acid-washed spent shales.

Liquid-state ${ }^{13} \mathrm{C}$ and ${ }_{\mathrm{H}}$ NMR measurements were made on a JEOI FX -270 WMR spectrometer at the University of Wyoming. All samples were prepared with a sample-to-solvent volume ratio of $1: 1$ by using $0.5 \mathrm{~mL}$ of $\mathrm{CDCl}_{3}$ containing 0.38 tetramethylsilane (TMS). The observed frequencies for ${ }^{\mathrm{H}}$ and ${ }^{13_{\mathrm{C}}}$ were 269.65 and $67.88 \mathrm{MHz}$, respectively. Proton NMR spectra were obtained using a pulse width of $5 \mu \mathrm{s}\left(46^{\circ}\right)$, a pulse delay of $20 \mathrm{~s}$, and a total of five transients. Carbon-13 spectra were obtained using a pulse width of $6 \mu \mathrm{s}\left(90^{\circ}\right)$ and a pulse delay of 20 s, with gated decoupling to ensure quantitative results. Typically, 1800 transients were recorded for the ${ }^{13} \mathrm{C}$ spectra. Proton and ${ }^{13} \mathrm{C}$ NMR spectra of the shale oils are shown on the data sheets in Appendix $B$.

\section{Simulated Distillations}

Simulated distillations of the Fischer assay shale oile were made to obtain minimal information on the quality of the shale oils. This procedure is a gas chromatogiaphic method for determining distillation profiles for organic materials that are not 1008 distillable below $538^{\circ} \mathrm{C}\left(1000^{\circ} \mathrm{F}\right)$. The chromatographic data are divided into desired distillate fractions from correlations of retention times and boiling points of normal alkanes. The concentration (wt 8 ) of each distillate fraction is determined using response factors obtained from standard samples. The results are reported as concentration (wt 8 ) distillable as a function of temperature. Miknis (1988) shows that a simulated distillation profile provides a lajthful reproduction of true boiling point distillation of a Tipton Member shale oil. However, simulated distillations require much less sample ( $\mu \mathrm{L}$ vs $I$ ) and less time than true boiling point distillations. Therefore, simulated distillations 
were determined on the shale oils (Table A-4, Appendix $A$ ). (The boiling ranges were chosen to correspond to those of the true bolling point distillation (Gary and Handwerk 1.975). Simulated distillations of the shale oils are shown in histographic form on the data sheets in Appendix B.

\section{RESULTS AND DISCUSSION}

The oil shales used for this study came from various deposits throughout the world and exhibit Fischer assay oil yialds ranging from a high cf 58 wt 8 (156 gpt) to a low of 2.4 wt 8 (7 gpt) (Figure 6). The Alaskan and Turkish-Göynük oil shales had Fischer assay oil yields in excess of $100 \mathrm{gpt}$, and they are the exception rather than the rule in terms of oil shale richness. The remaining oil shales had oil yields ranging from 7 to $32 \mathrm{gpt}$ which is a more typical range. Fischer assay conversion data are summarized in Table A-1, Appendix $A$, and are presented histographically in Figures 6 and 7.

Despite the apparent variaticns in oil yields for shales with similar overall aliphetic carbon contents, the carbon content of the oils correlates linearly with the raw shale aliphatic carbon contents over a large range of carbon contents (Figure 8), reaffirming similar correlations found previously (Maciel et al. 1978, 1979; Miknis 1982). The aromatic carbon content of the spent shale also correlates with the raw shale aromatic carbon content (Figure 9), reaffirming previously observed correlations (Miknis et: al. 1982b, Miknis and Conn 1986). The important features of Figures 8 and 9 are that aromatic and aliphatic carbon contents can be used to predict some of their conversion behavior.

The solid-state NMR spectra (Figure 4) for the Alaskan and TurkishGöynük shales are very similar. Both spectra show evidence of carboxyl $(170 \mathrm{ppm})$, carbonyl $(200 \mathrm{ppm})$, and methoxy (70 ppm) resonances in addition to a narrow aliphatic carbon band and a small aromatic carbon band.

The NMR spectra of the other oil. shales (Figure 4) are relatively featureless, showing only the typical bxoad aliphatic and aromatic carbon bands. The Kentucky oil shale spectrum illustrates the high aromaticity of these shales, which is largely responsible for their low carbon conversions to oil (Miknis and smith 1984). The Turkishseyitömer oil shale shows a low conversion to oil, considering the fairly high aliphatic carbon content of this shale. other studies of the conversion of Turkish oil shales have found similar results (Putun et al. 1988). One reason for the low oil yield may be the higher gas yield, relative to oil yield, for this shale. The Australian, chinaMaoming, and Moroccan oil shales also show low conversions to oil relative to what $j$ s expected based on their aliphatic carbon contents.

The combined use of solid- and liquid-state ${ }^{13} \mathrm{C}$ NMR, in conjunction with the material balance Fischer assay conversion data, allows some inferences to be made about the extent of aromatization reactions during Fischer assay. During pyrolysis, there is an increase in the 


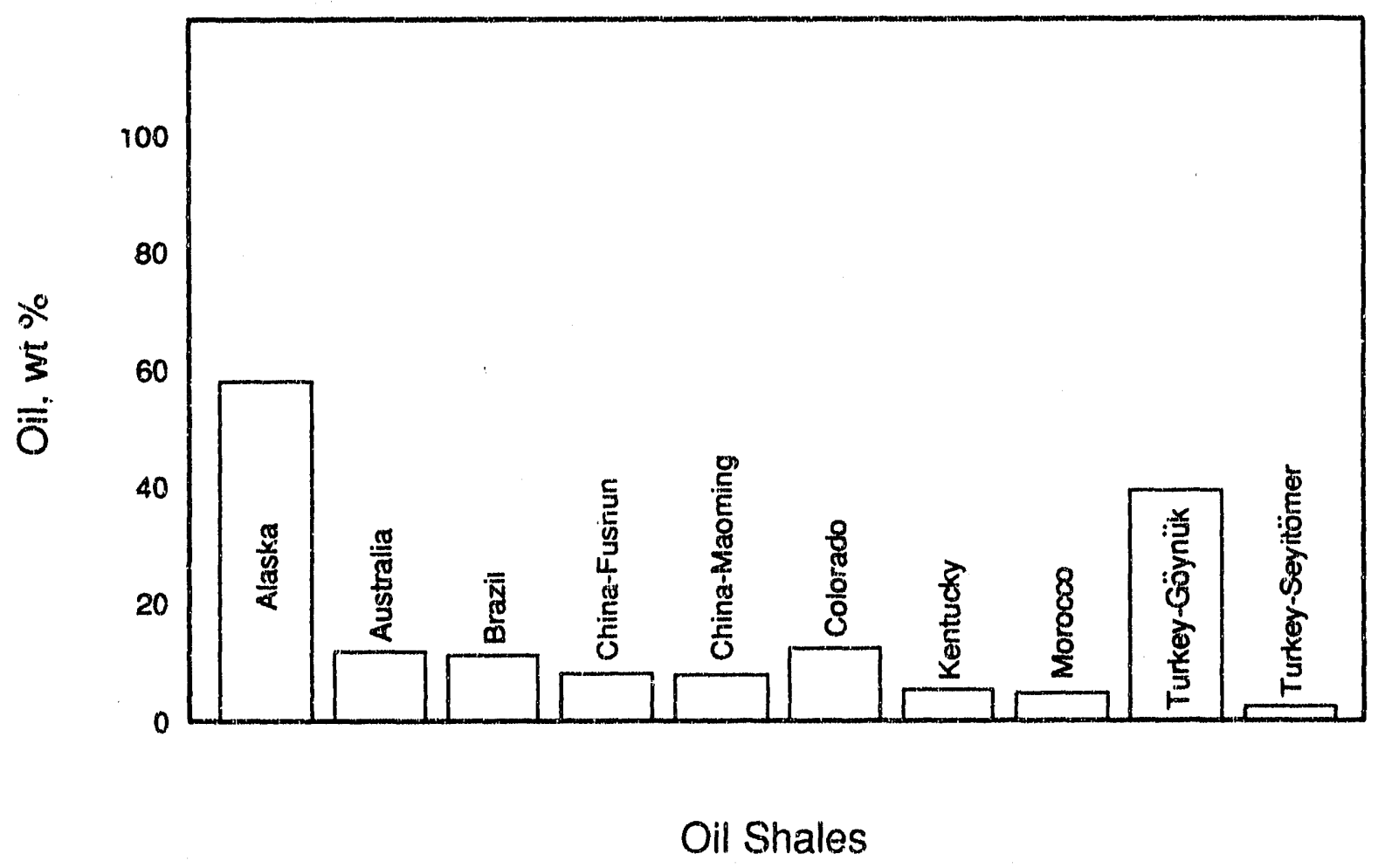

Figure 6. Fisher Assay Oil Yields 


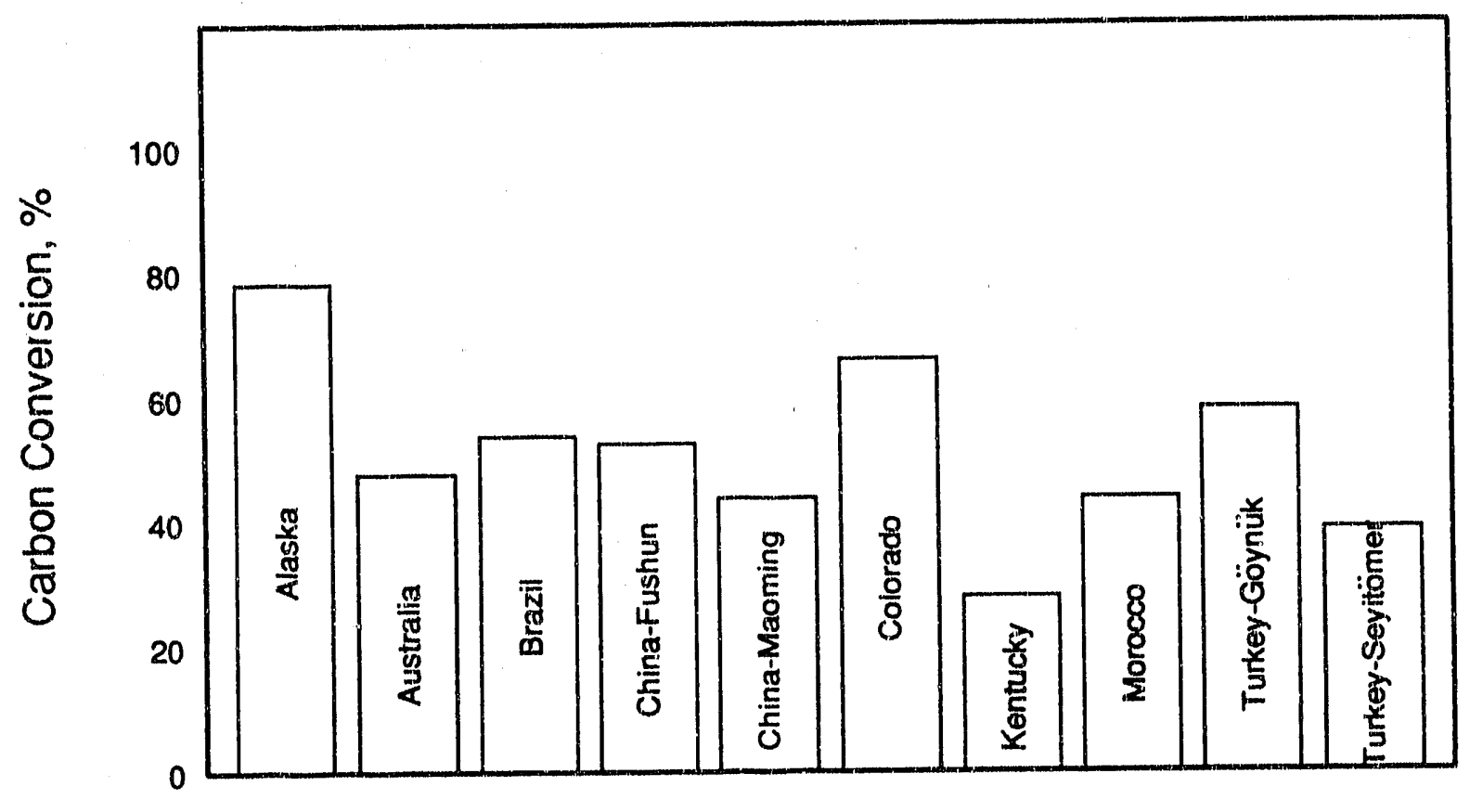

Oil Shales

Figure 7. Carbon Conversion to Oil during Fischer Assay 


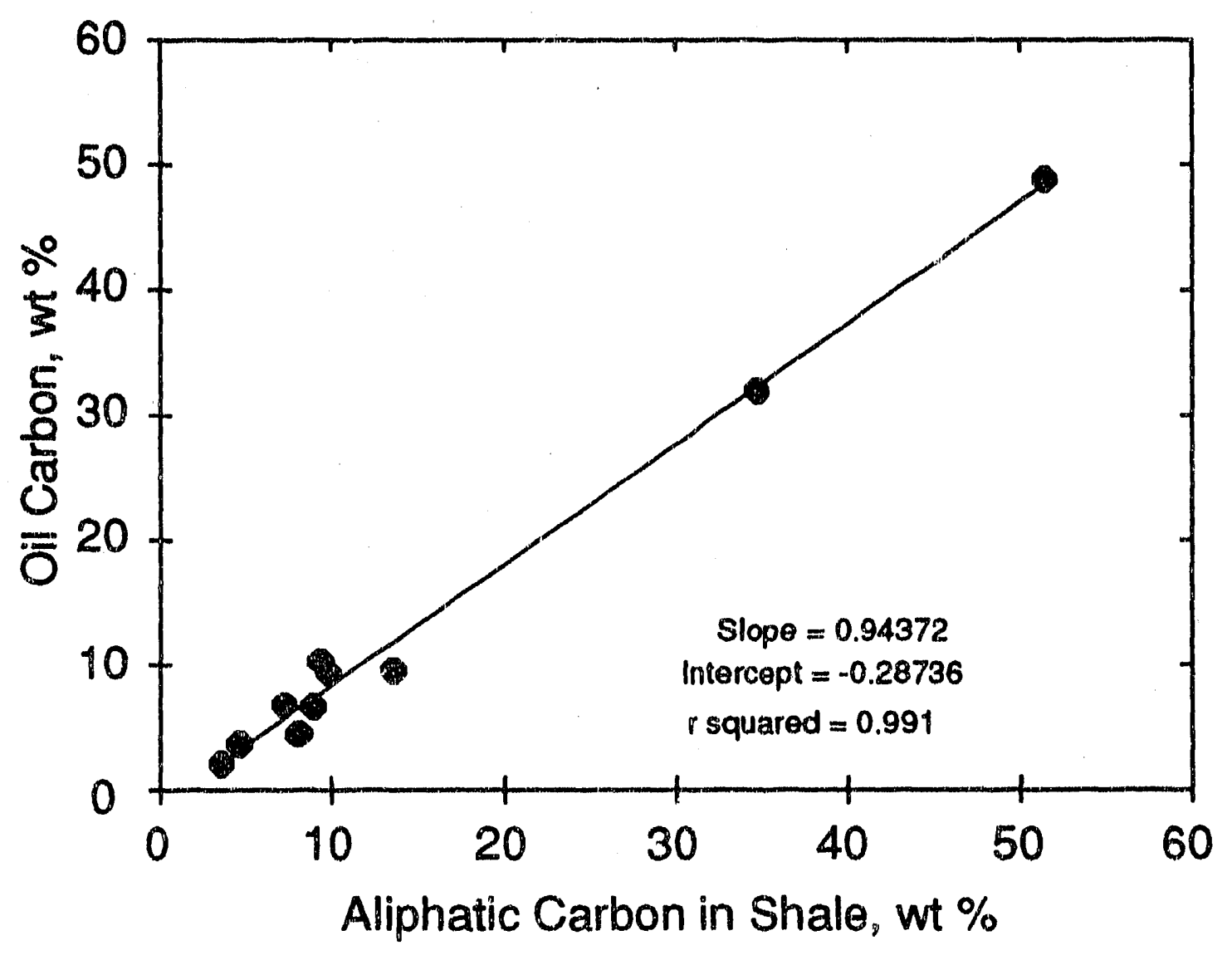

Figure 8. Correlation between Aliphatic Carbon in Raw shale and Carbon in the Fischer Assay Oil 


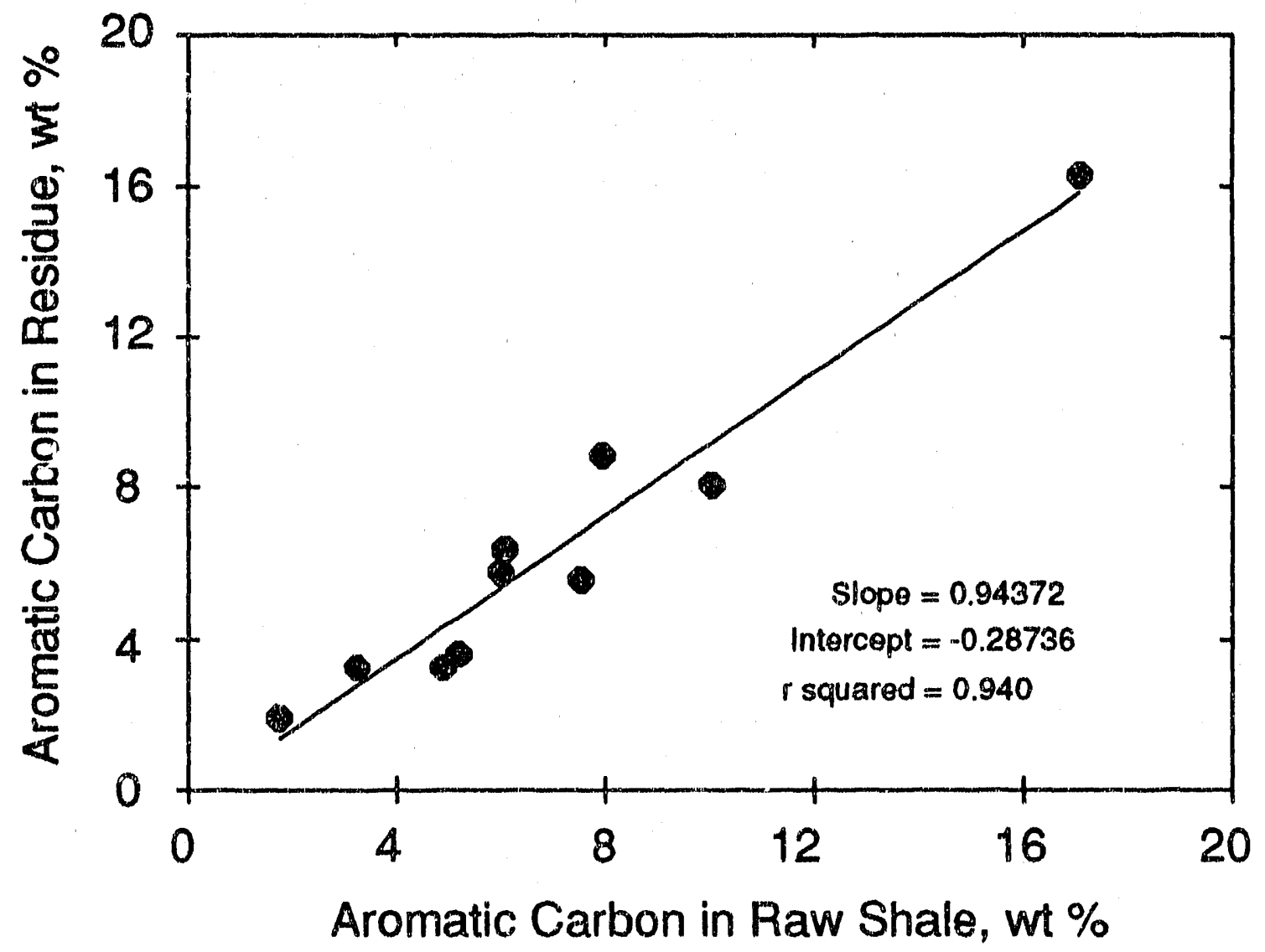

Figure 9. Correlation between Raw shale Aromatic Carbon and Residue Aromatic Carbon 
amount of aromatic carbon in the products (oil plus residue) over that in the original shale (Hershkowitz et al. 1983; Burnham and Happe 1984). This increase is produced at the expense of aliphatic carbon moieties, which produce aromatic carbon either by dehydrogenation of hydroaromatic structures or by ring closure of alkyl groups followed by dehydrogenation (Vassallo et al. 1987).

The carbon balance Fischer assay data are listed in Appendix B for each shale and are summarized in Table 1 for the set of 10 shales. The carbon data are normalized on the basis of 100 carbon atoms (Hershkowitz et al. 1983). Figure 10 and Table 1 show that the Alaskan shale has the greatest loss of aliphatic carbons (22) to aromatization reactions. The Australia, Kentucky, Morocco, and Turkey shales also show substantial losses of aliphatic carbons to aromatization reactions. When plotted as a percentage of the raw shale aliphatic carbons, a more realistic comparison of the importance of aromatization reactions for the shales is obtained (Figure 11). The Kentucky, Morocco, and Turkey-Seyitömer oil shales show the greatest percentage decrease in aliphatic carbons. These shales also show the lowest carbon conversions to oil and the highest carbon conversions to residue.

The implication of these observations is that coking (aromatization) reactions are more prevalent in, the Kentucky, Morocco, and Turkey-Seyitömer shales. However, it cannot always be established to what extent these reactions occur in the solid or liquid state. For the Alaska shale (Appendix B), the net effect of the aromatization reactions is to produce oil because the number of aromatic carbons in the raw shale (16) is not sufficient to account for the number of aromatic carbons in the oil (25). For the rest of the shales, the number of aromatic carbons in the shale oil is substantially less than the number of aromatic carbons in the raw shale. Consequently, the origin of the aromatic carbons in the shale oil is not conclusive. In the case of the Kentucky shale, the number of aromatic carbons in the raw shale (49) is not sufficient to account for the number of aromatic carbons in the residue (56). Therefore, at least seven of the $x$ aw shale aliphatic carbons formed aromatic carbons in the residue, assuming that coking of the shale oil vapor did not occur during Fischer assay.

The ratio of the number of aromatic carbons in the residue to the number of aromatic carbons in the raw shale was calculated for the 10 shales (Figure 12). If this ratio is greater than unity, then the minimum number of aliphatic carbons that aromatized to form residue can be determined. If the ratio is less than unity, the source of the residue aromatic carbons can not be determined. Figure 12 shows that the Australia, Kentucky, and Turkey-seyitömer oil shales have ratios greater than unity, suggesting that the aromatization reactions to form coke are most prominent in these shales. The Morocco, China-Maoming, and Turkey-Göynük shales have ratios close to unity (>0.93). Except for the rurkey-Göynük shale, all of the shales with ratios greatex than or near unity show the lowest carbon conversions to oil during Fischer assay. The data in Figure 12 suggest that the shales can be divided 


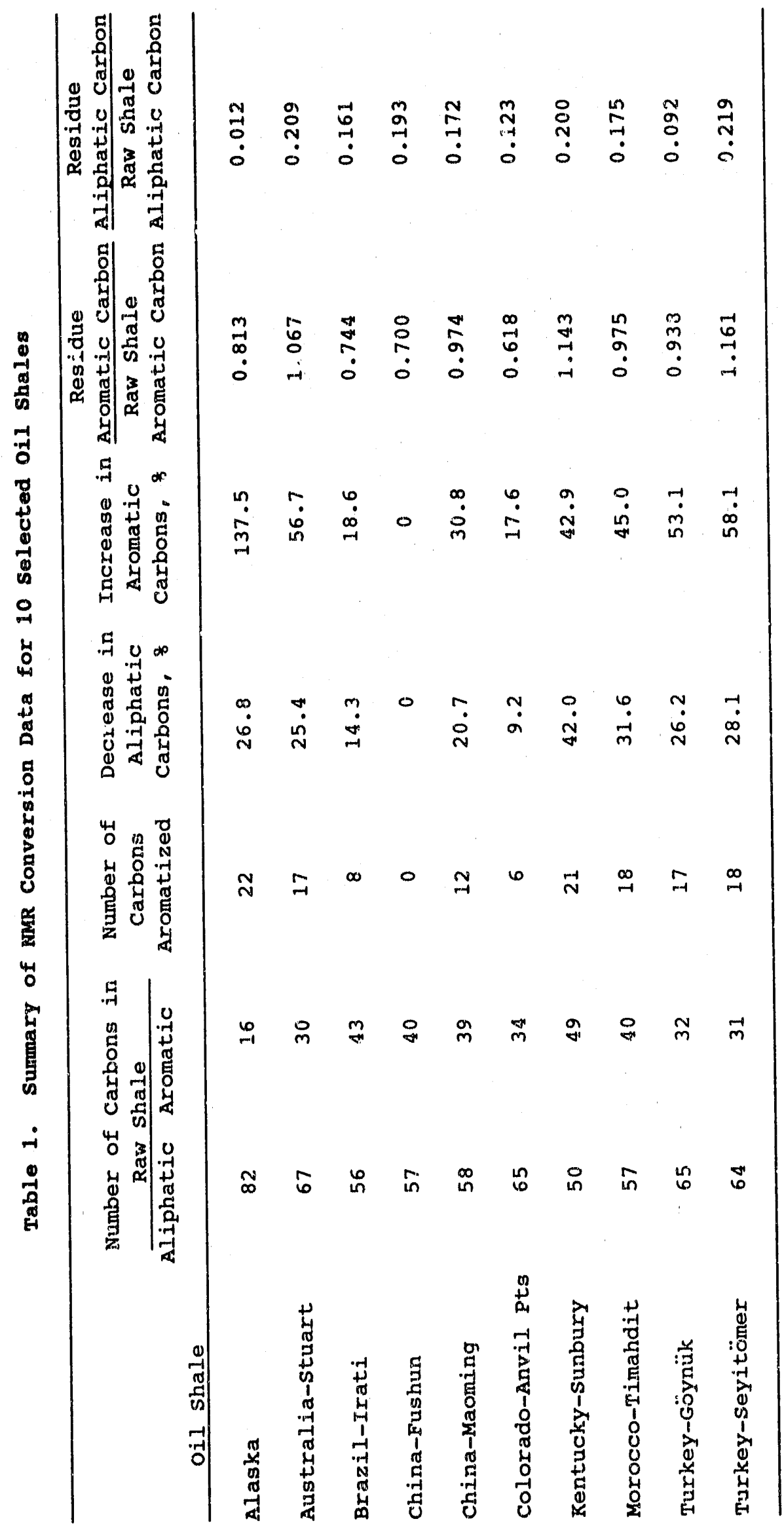




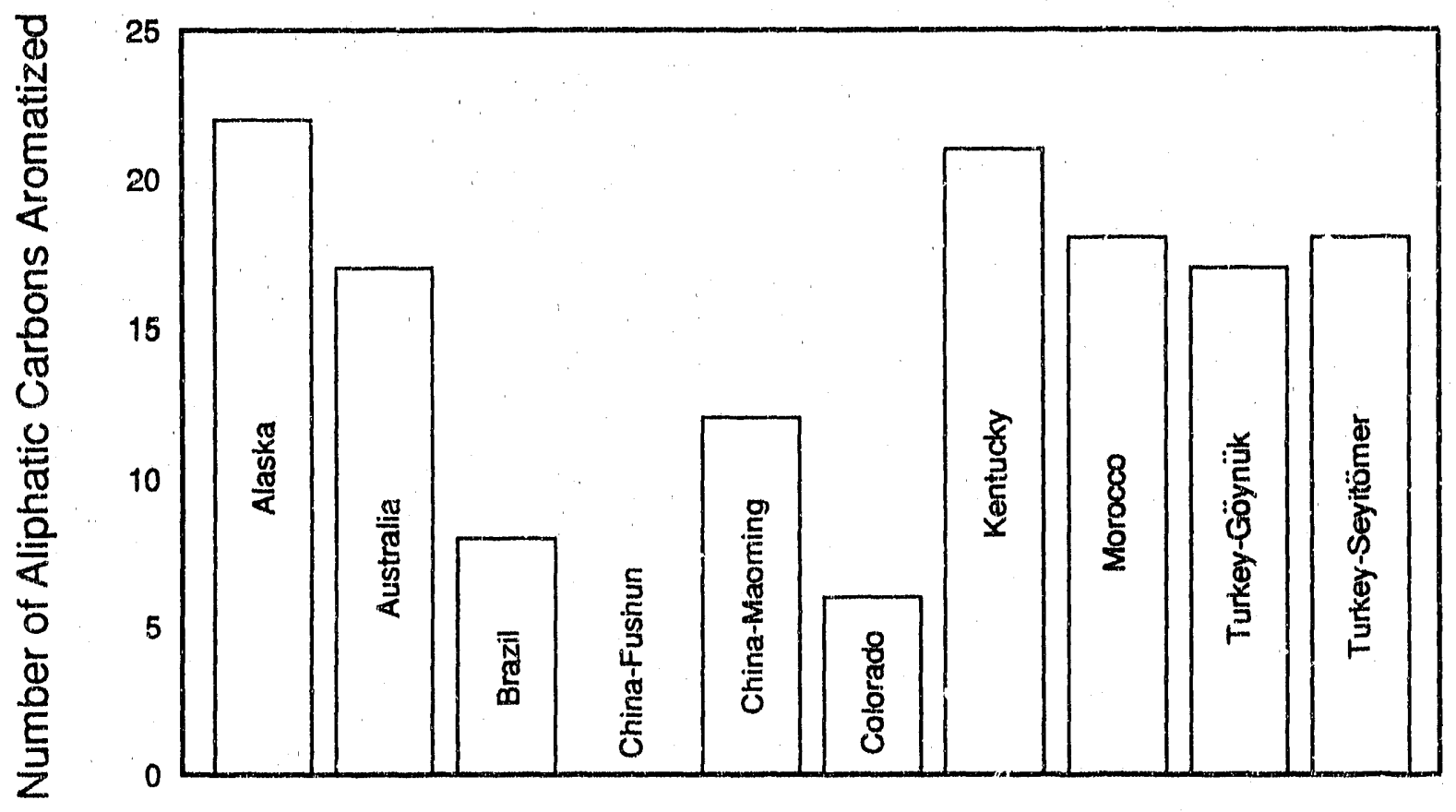

Oil Shales

Figure 10. Number of Raw Shale Aliphatic Carbons Aromatized during Fischer Assay 


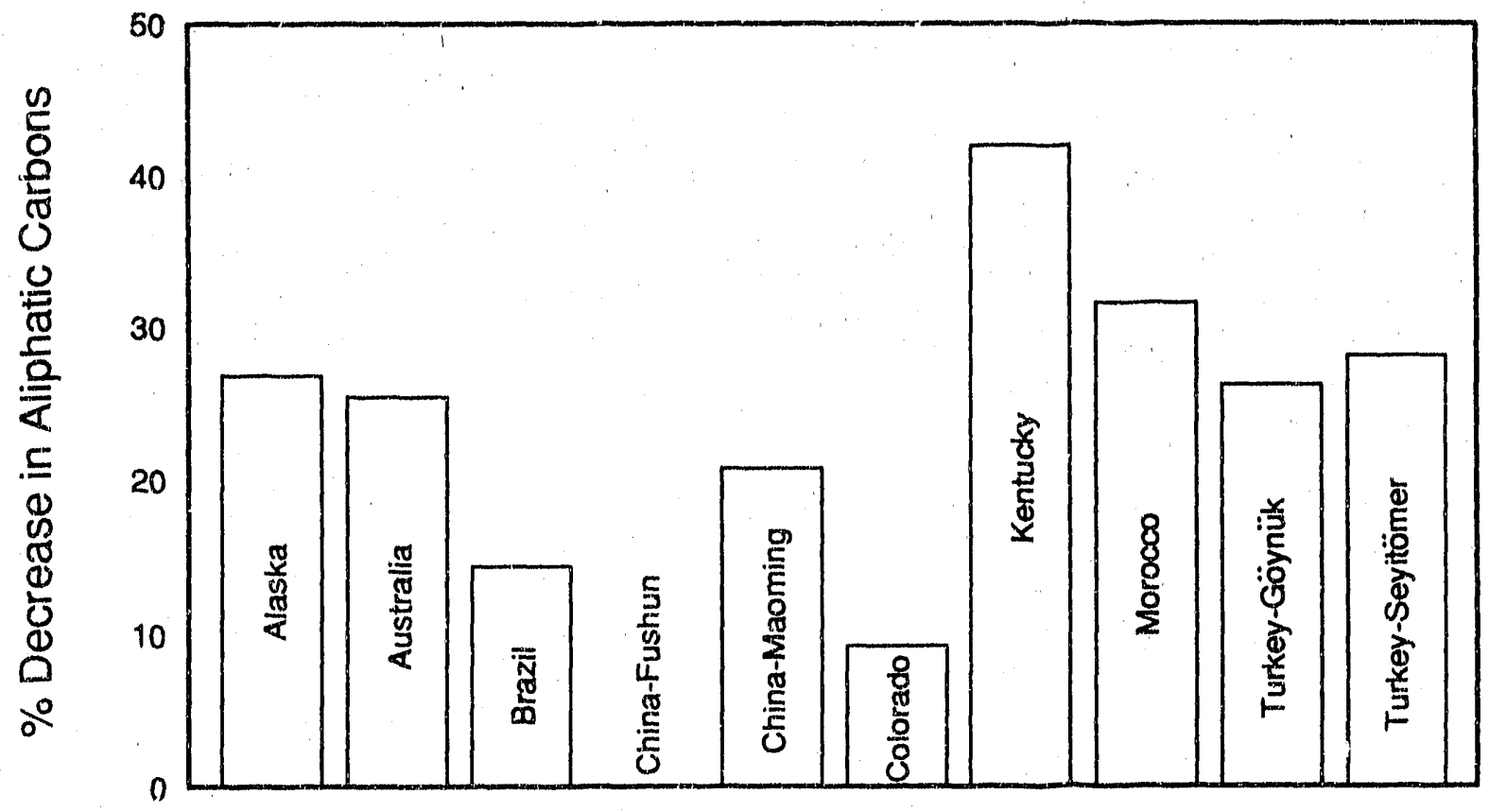

Oil Shales

Figure 11. Percent Decreases in Raw shale Aliphatic Carbons during Fischer Assay 


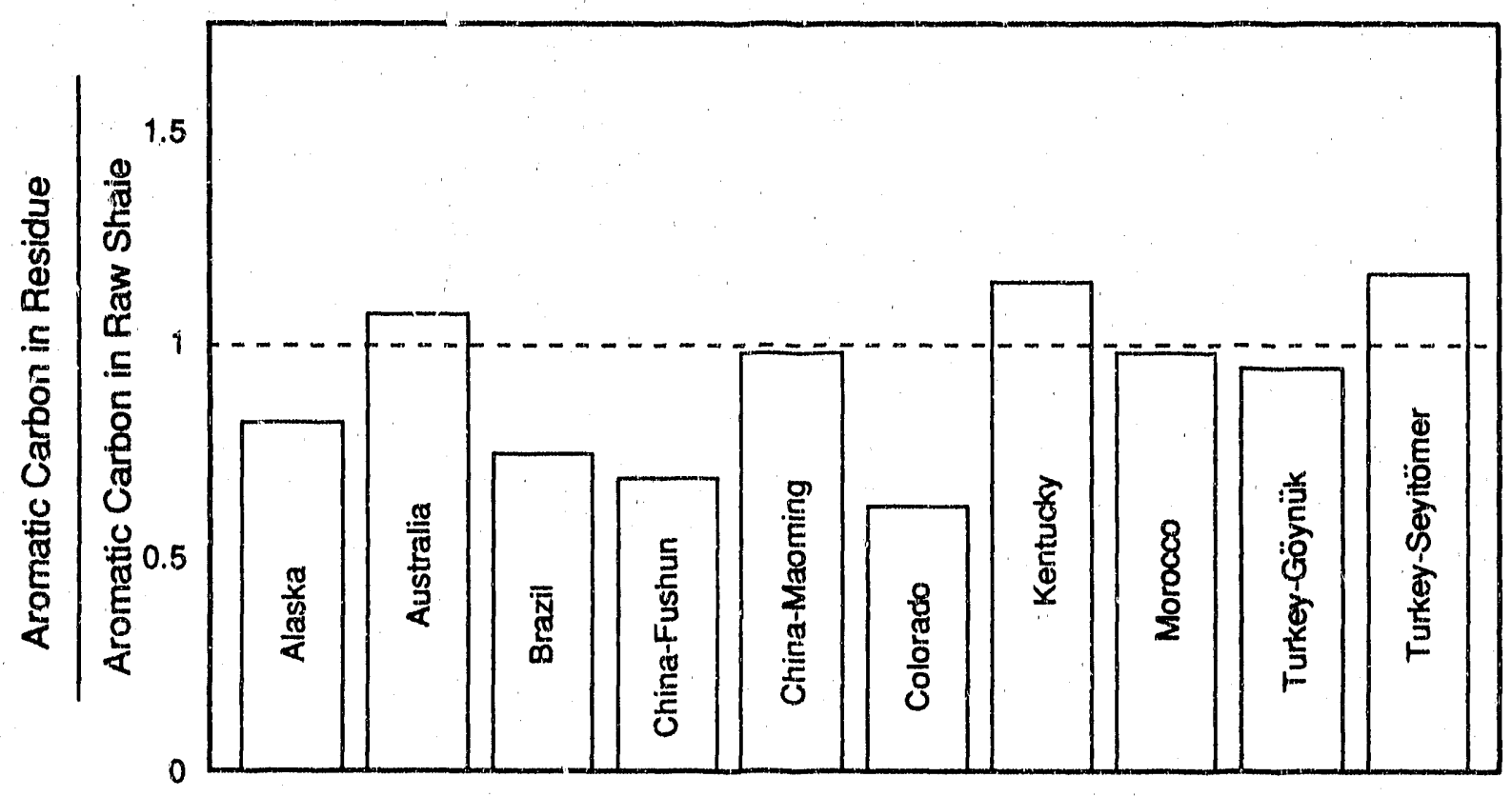

Oil Shales

Figure 12. Ratio of Aromatic Carbons in Residue to Aromatic Carbon in Raw Shale 
into three groups with regard to coking tendency, based on the ratio of residue aromatic carbon to raw shale aromatic carbon. Thus, the coking tendency is Australia, Kentucky', Turkey-Seyitömer > China-Maoming, Morocco, Turkey-Göynük > Alaska, Erazil, China-Fushun, Colorado.

A certain amount of aliphatic carbon ends up as aliphatic carbon in the residue. Although these carbong are not involved in coking reactions, they represent a loss in oil potential. These carbons are, most likely, short-chain (methyl, ethyl) aliphatic carbons attached to aromatic rings. Figure 13 shows the aliphatic carbon content of the residue, expressed as a percentage of the raw shale aliphatic carbon. The interesting feature of these data is that this percentage is in the range of 10 to 20 \& for most of the shales, independent of original kerogen structure and conversion behavior.

\section{Shale oil Analyses}

A limited number of analyses were performed on the shale oils to obtain information about the quality of the shaie oils. These data, summarized on the data sheets in Appendix B, include a liquid-state NMR determination of the hydrogen and carbon aromaticity, a VPo molecular. weight determination in toluene, and a simulated distillation of the shale oil.

The molecular weights of the shale oils (Figure 14) are quite constant, having a mean of $293 \pm 28$ (958 confidence) daltons. The carbon and hydrogen aromaticities and the specific gravities of the oils are quite variable (Table A-2). Thus, a shale oil molecular weight is not a good indicator of compositional differences among the shale oils and is more likely to indicate the temperature at which the oil was produced.

The carbon and hydrogen aromaticities show considerable variation among the shale oils (Table $\mathrm{A}-2$ ). These data do not suggest any relationship between the raw shale carbon aromaticity and shale oil carbon aromaticity. In some cases, the oil aromaticity is greater than that of the raw shale, whereas in other cases, it is less. However, the Kentucky, Morocco, and Turkey-seyitömer oil shales, which have tentatively been identified as having a high tendency to coke, produce the more aromatic shale oils. In general, a visual inspection of the NMR spectra can provide a qualitative assessment of the shale oil. composition. This is most readily done by examining the aliphatic region $(0-50 \mathrm{ppm})$ of the ${ }^{13} \mathrm{C}$ NMR spectrum. The resonance at $\sim 30 \mathrm{ppm}$ is due to $\mathrm{CH}_{2}$ carbons in straight-chain aliphatic compounds having at least nine carbons. The resonance at $\sim 14 \mathrm{ppm}$ is due to the termiral methyl groups. The intensity of the $\mathrm{CH}_{2}$ resonance relative to that of the methyls is an indicator of the aliphatic carbon chain length. The spectra in Appendix B for the Australia, China, colorado, and both Turkey shale oils have aliphatic carbon resonance patterng that show the presence of straight-chain aliphatic compounds. Aliphatic carbon patterns, such as that exhibited by the Brazil shale oil, are indicative of branched and/or cyclic parafinic carbons. Terminal olefinic carbons are present in all of the shale oils, as shown by the 


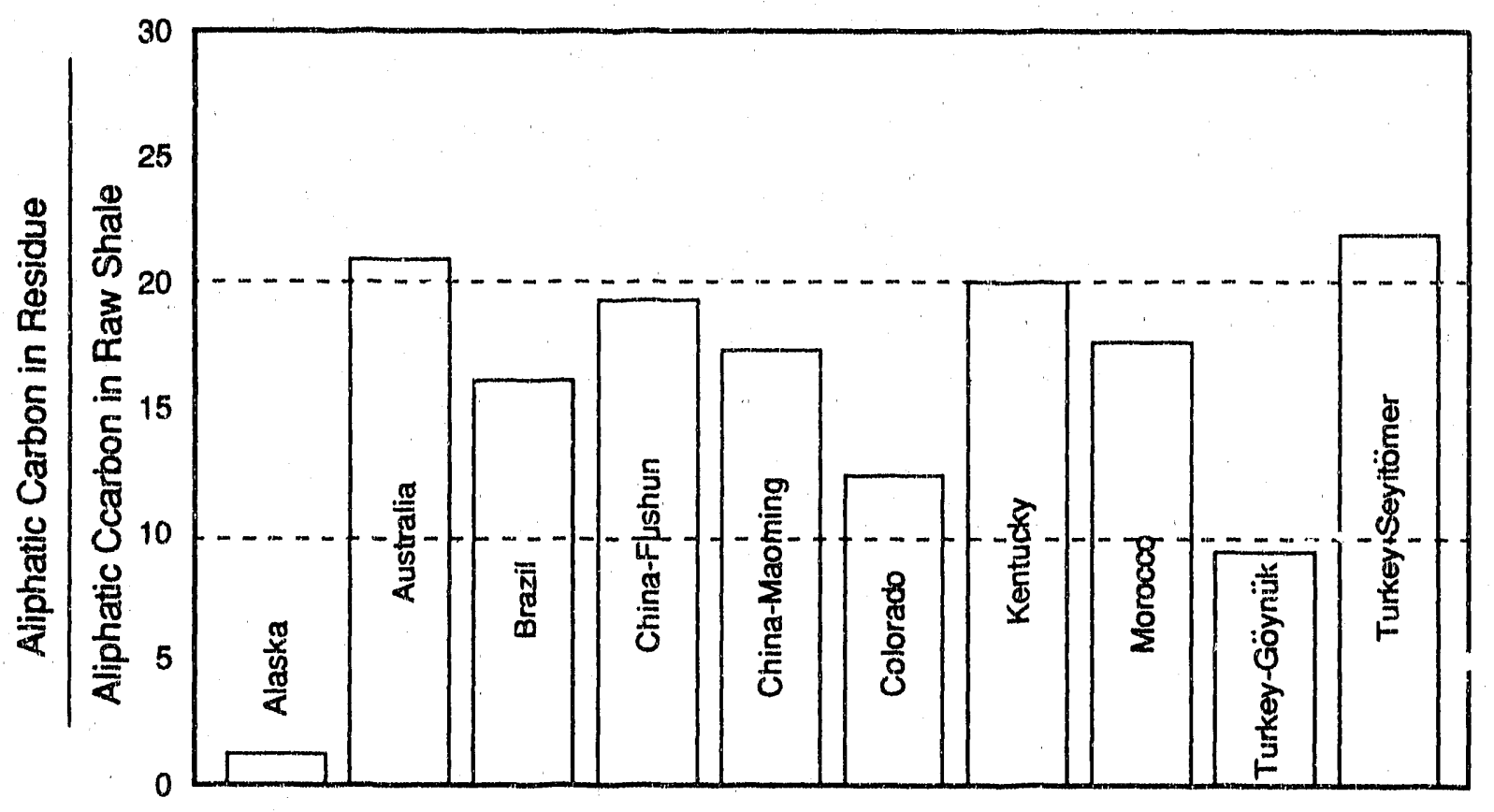

Oil Shales

Figure 13. Percent of Raw shale Aliphatic carbons in Residue 


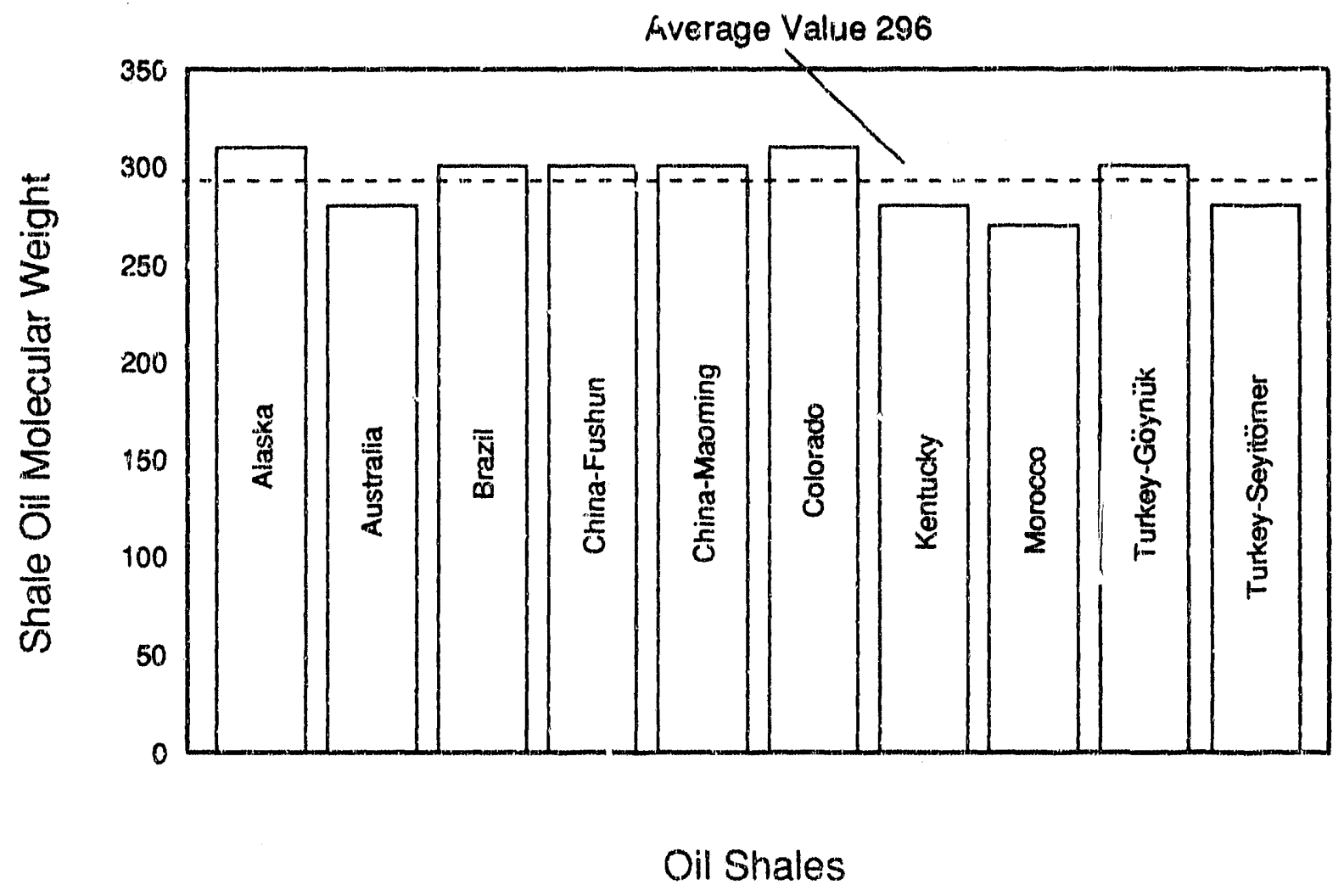

Figure 14. Shale OiI Molecular Weights 
shaxp resonances at 114 and $138 \mathrm{ppm}$ in the aromatic region. The aromatic carbon resonances are typified by a broad band with some narrow resonances superimposed. Detailed interpretation of the NMR spectra was beyond the scope of the work.

Simulated distillations were obtained on the shale oils to provide nominal data about the distillation properties of the oils (Table A-4). The boiling ranges were chosen to correspond to true boiling point distillation fractions. These data are plotted in histographic form on the data sheets in Appendix B. The amount of distillate in each of the fractions does not differ significantly among any of the shale oils, except for possibly the residuum. The bulk of the oil ( $>508$ ) distills in two boiling ranges, the atmospheric and vacuum gas oil fractions. The temperature at which 508 of the material has distilled of determined for the shile oils (Figure 15). The average 508 off temperature for all the shale oils is $369^{\circ} \pm 16^{\circ} \mathrm{C}\left(696^{\circ} \mathrm{F} \pm 60^{\circ} \mathrm{F}\right)(958$ confidence). This temperature is close to the average temperature of the atmospheric gas oil fraction, which is $374^{\circ} \mathrm{C}\left(705^{\circ} \mathrm{F}\right)$.

\section{SUMMARY AND CONCLUSIONS}

During pyrolysis of solid fossil fuels in an autogenous atmosphere there is a net increase in the amount of aromatic carbons in the products over that found in the starting material. The increase in aromatic carbon is caused by aromatization reactions of the aliphatic moieties in the material. Aromatization reactions axe precursors for coke formation. Whether the aromatization reactions occur predominantly from the starting material or from reaction intermediates, affects the conversion behavior of the fossil fuel, particularly for liquids generation. Therefore, developing a method whereby the extent of aromatization can be determined for a given process is important for process optimization.

The amount of aliphatic carbon that aromatized during Fischer assay ranged from zero to 428 for the 10 shales. Shales having the lowest Fischer assay conversions ta oil showed the highest extent of aromatization. For three of the shales, the amount of axomatic carbon in the residue was greater than the amount of aromatic carbon in the raw shale. Because the aromatic carbon in the products is distributed between the oil and residue, it was not possible to determine unequivocably if aromatization took place from the starting material, or from a reaction intermediate.

The carbon residue on the spent shale contained between 10 and 208 of the raw shale aliphatic carbon. Most of this carbon may consist of short-chain alkyl substituents attached to aromatic rings.

Molecular weights and sinulated distillations wexe obtained on the shale oils produced from the Fischer assay. The molecular weights ranged from 270 to 310 daltons, with an average of 296 daltons. The temperature at which 508 of the shale oil distilled ranged from 349 


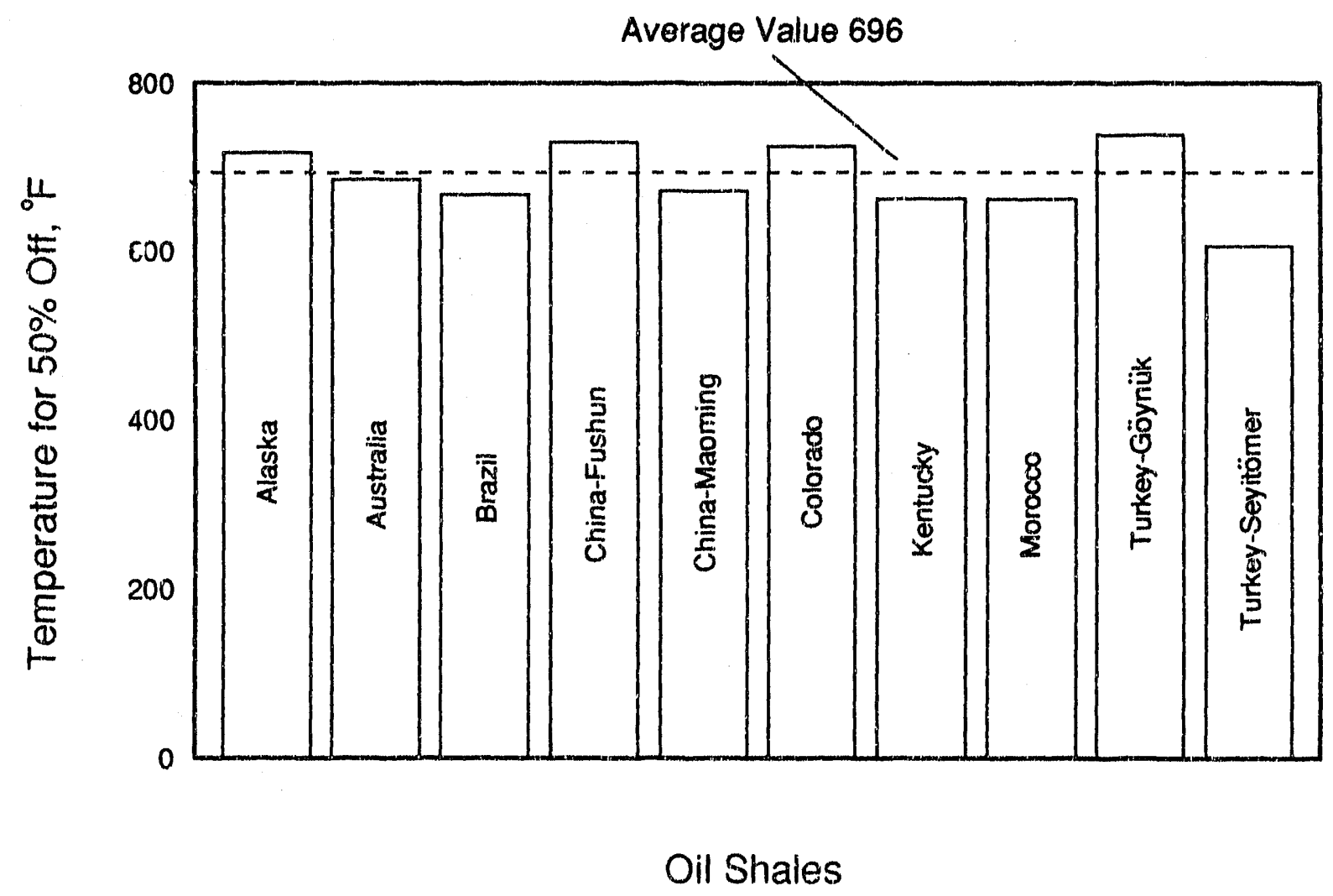

Fjgure 15. Temparature at which 50 wt of shgle oil Digtills 
(661) to $392^{\circ} \mathrm{C}\left(738^{\circ} \mathrm{F}^{\prime}\right)$, with an average of $369^{\circ} \mathrm{C}\left(696^{\circ} \mathrm{F}\right)$. This value is close to the mean temperature of the atmospheric gas oil fraction, which is $374^{\circ} \mathrm{C}\left(705^{\circ} \mathrm{F}\right)$. 


\section{ACKNOWLEDGMENTS}

The author gratefully acknowledges support of this work by the U.S. Department of Energy under Cooperative Agreement DE-FC21-86MC11076. In addition, the author wishes to acknowledge Dr. R. Baldwin, Colorado School of Mines, for the Australia oil shale sample, Mr. Ed Piper, stone \& Webster Engineering Corporation for the Brazil oil shale and Dr. E. Ekinci, Istanbul Technical University, for the rurkey oil shales. The solid-state NMR spectra were provided by Professor G. Maciel, Colorado state University. Mr. Gardner of Western Research Institute provided the material balance Fischer assays.

\section{DISCLAIMER}

Mention of pecific brand names or models of equipment is for information only and does not imply endorsement of any particular brand. 


\section{REFERENCES}

Burnham, A.K., and J.A. Happe, 1984, on the Mechanism of Kerogen Fyrolysis. Fuel, 63: 1353-1356.

Gary, J.H., and G.E. Handwerk, 1975, Petroloum Refining Technology and Economics. Marcel Dekker, New York, NY, 365 p.

Hershkowitz, F., W.N. Olmstead, R.P. Rhodes, and K.D. Rose, 1983, Molecular Mechanism of oil Shale Pyrolysis in Nitrogen and Hydrogen Atmospheres, in Miknis, F.P., and J.F. McKay, eds., Geochemistry and Chemistry of oil shaleg. Amer. Chem. Soc., Washington, DC, symp. Series 230 , Ch. 15.

Maciel, G.J., V.J. Bartuska, and F.P. Miknis, 1978, A Correlation Between oil yields of oil shales and ${ }^{13} \mathrm{C}$ Nuclear Magnetic Resonance spectra. Fuel, 57: 505 .

Maciel, G.E., V.J. Bartuska, and F.P. Miknis, 1979, Improvement in Correlation Between oil Yields of $0 i l$ shales and ${ }^{13} \mathrm{C}$ NMR spectra. Fuel, 58 : 155 .

Miknis, F.P., 1982, NMR studies of Solid Fossil Fuels. Magnetic Reson. Reviews, 7: 87-122.

Miknis, F.P., 1988, Characterization of DoE Reference oil shale: Tipton Member, Green River Formation oil shale from Wyoming. Laramie, WY, DOE report DOE/MC11076-2676.

Miknis, E.P., and P.J. Conn, 1986, A Common Relation for Correlating pyrolysis Yields of Coals and oil Shales. Fuel, 65: 248-250.

Miknis, F.P., and J.W. Smith, 1984, An NMR Survey of United states Oil shales. Org. Geochein. (I.A. Breger Memorial Issue), 5; 193-201.

Miknis, F.P., D.A. Netzel, J.W. Smith, M.A. Mast, and G.E. Maciel, $1982 \mathrm{a},{ }^{13} \mathrm{C}$ NMR Measurements of the Genetic Potentials of oil shale. Geochim. Cosmochim. Acta, 46: 977-984.

Miknis, F.P., N.M. Szeverenyi, and G.E. Maciel, 1982b, Characterization of the Residual Carbon in Retorted oil shales by solid-state ${ }^{13} \mathrm{C}$ NMR. Fuel, 61: 341-345.

Putun, E., A. Akar, E. Ekinci, and K.D. Bartle, 1988, chemistry and Geochemistry of Turkish oil shale Kerogens. Fuel, 67: 1106-1110.

Smith, J.W., 1961, Ultimate Composition of organic Material in Green River oil shale. Laramie, WY, USBM RI 5725.

Vassal10, A.M., M.A. Wilson, and J.H. Edwards, 1987, 13C NMR Aromaticity Balances on Coal Flash Pyrolysis products. Fuel, 66 : 622-626. 
ARPENDIX A

Fischer Assay Conversion Data 


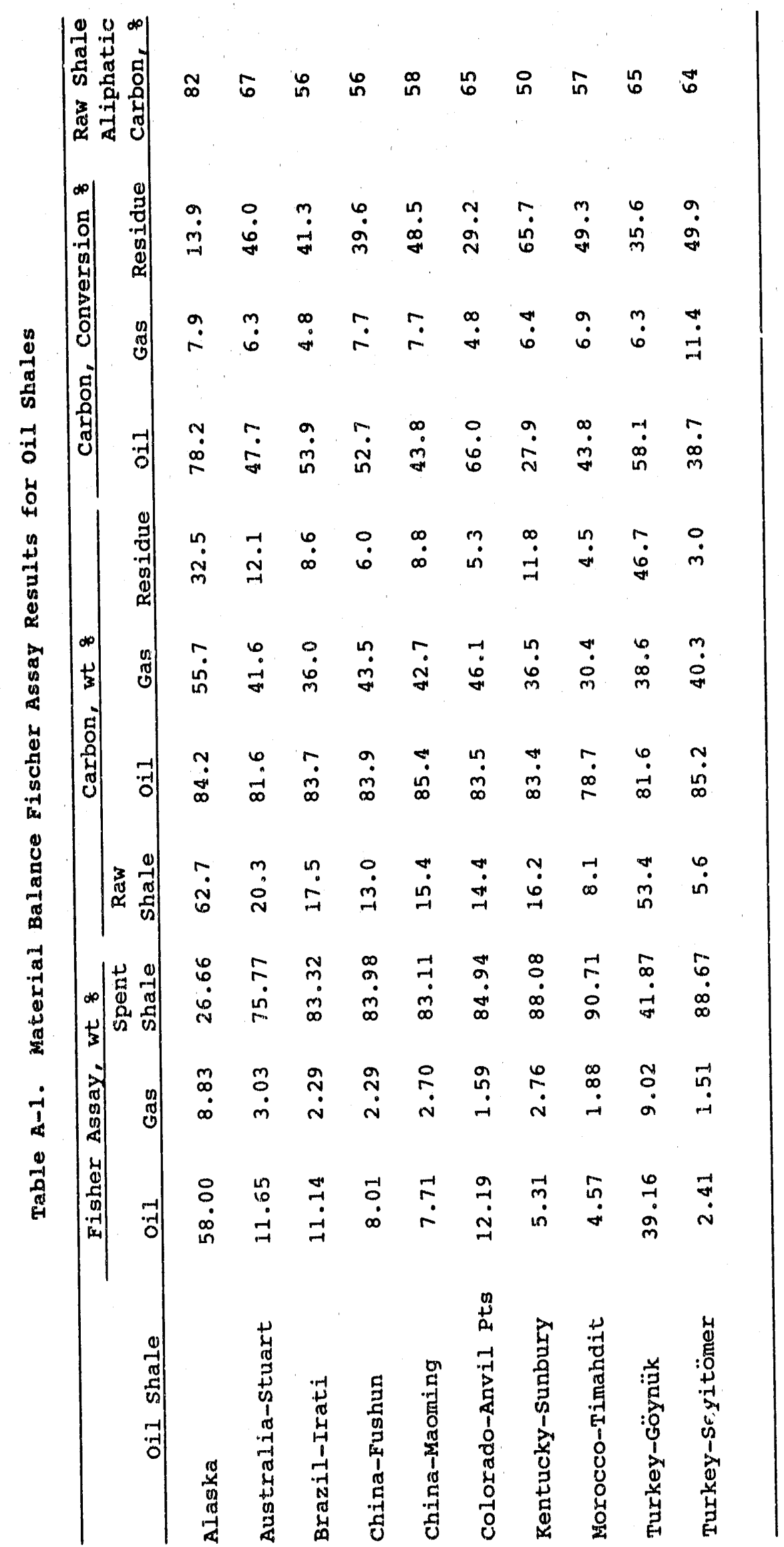




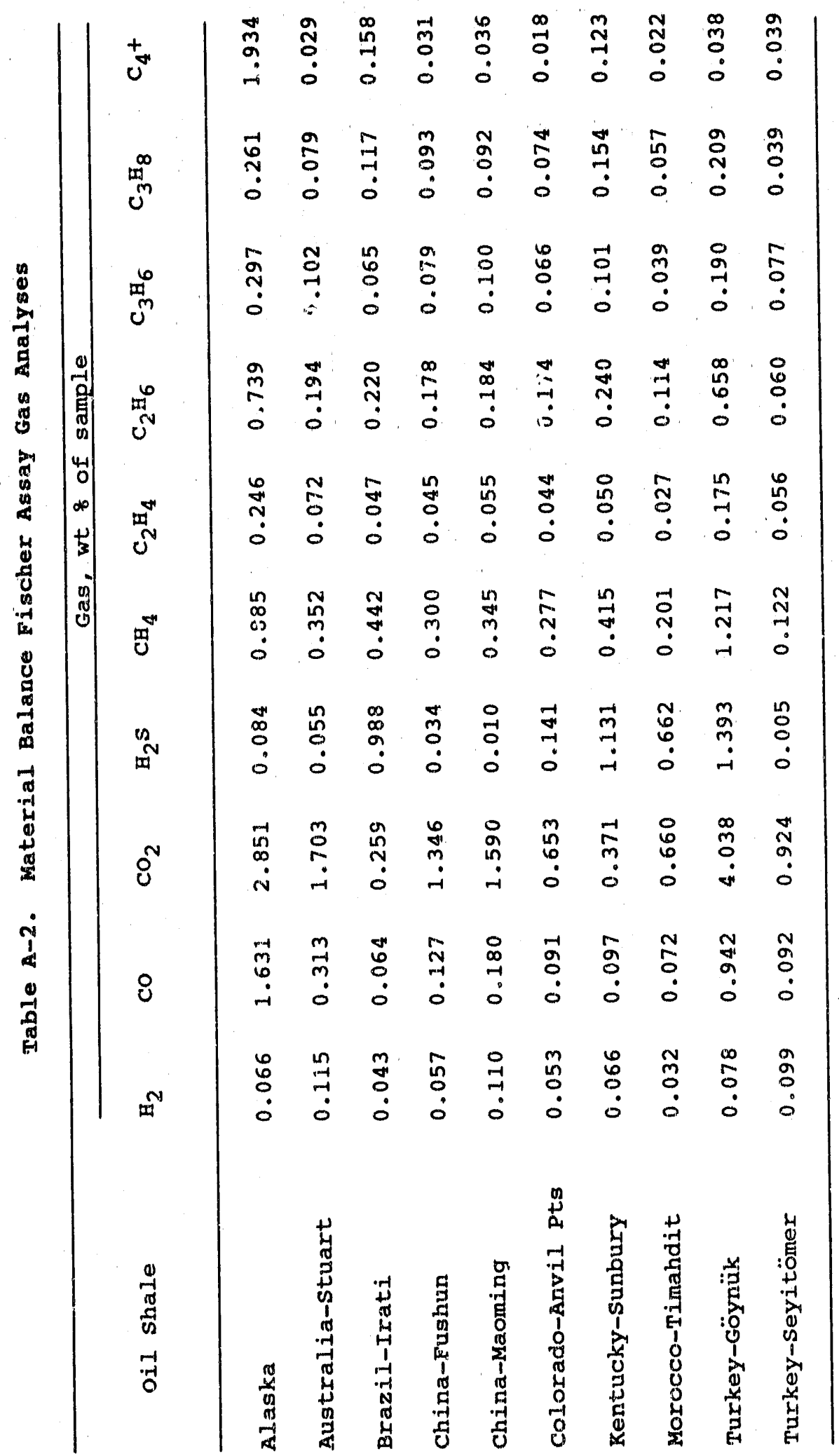




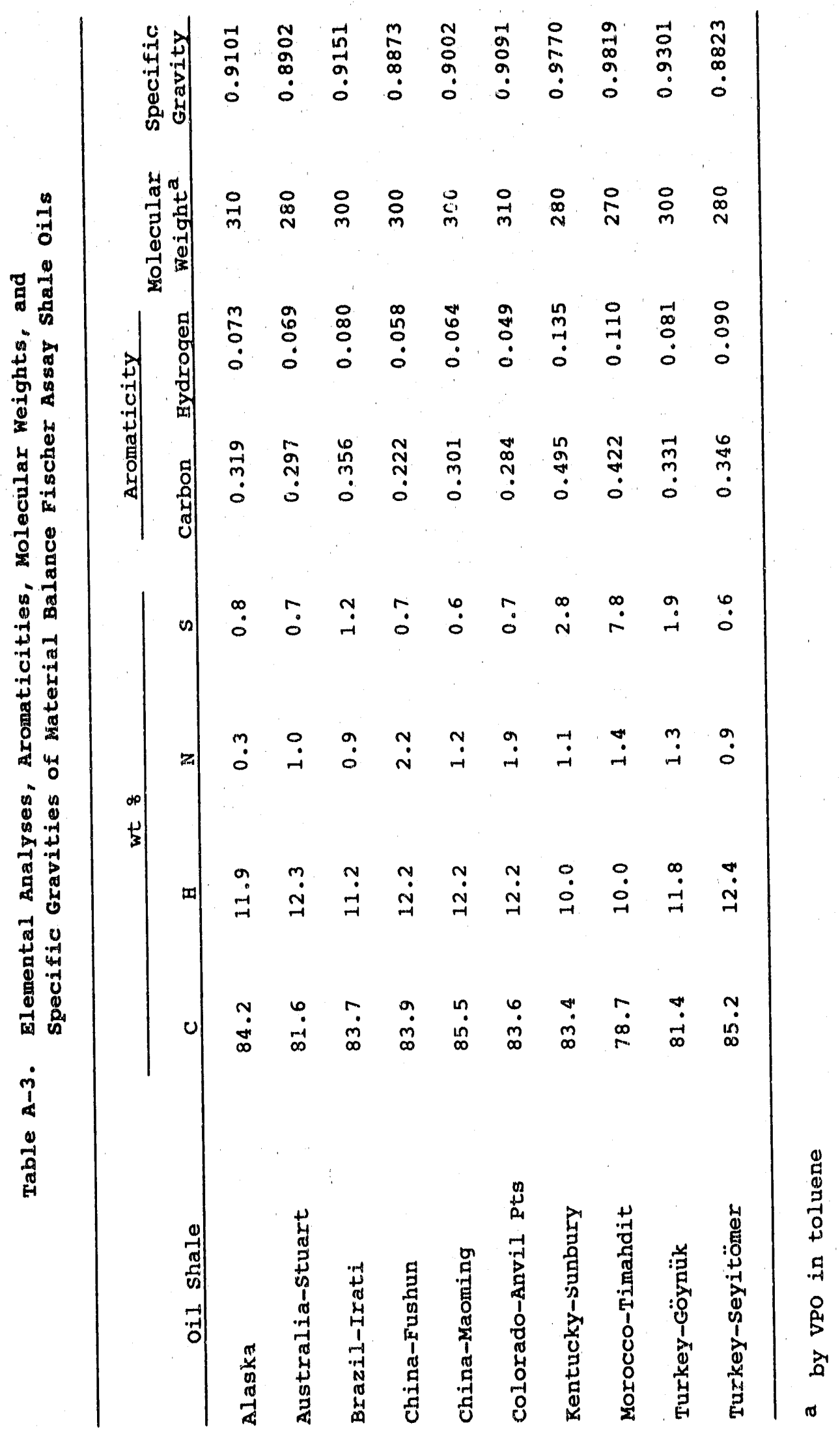




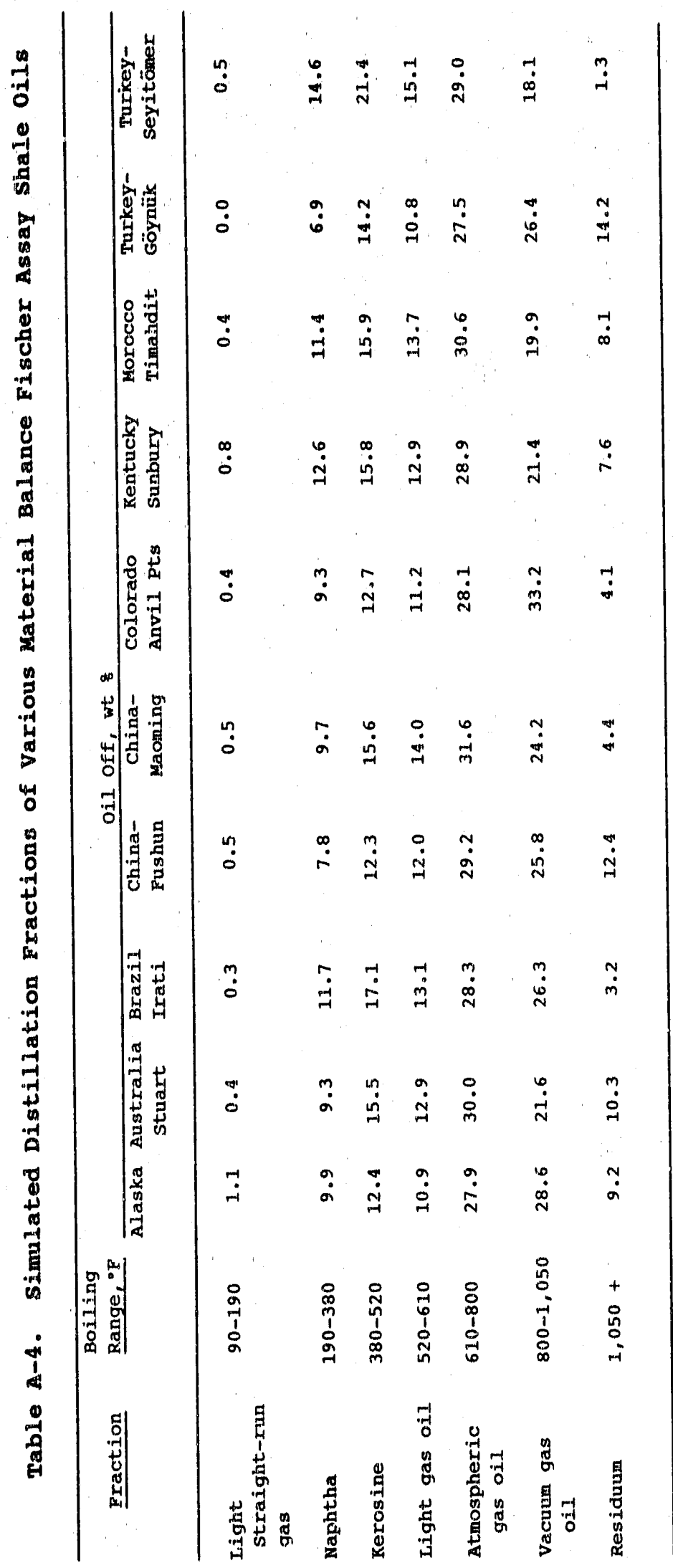




\section{APPENDIX B}

Oil shale Data sheet: 
The data acquired for each oil shith are summarized on data sheets in this appendix. The first page containg information about the converaion of the oll shale, including a carbon balance fischer assay that combines solid- and liquid-state NMR measurements with Fischer assay results. The second page of the data sheet provides minimal information about the shale oils. 


\section{WESTERN RESEARCH INSTITUTE OIL SHALE DATA SHEET}

Sample: Tiglukpuk oil shale

Geologic Age: Triassic

Depositional Environment: Marine

F. A. Oil Yield: $156.1 \mathrm{gpt}$

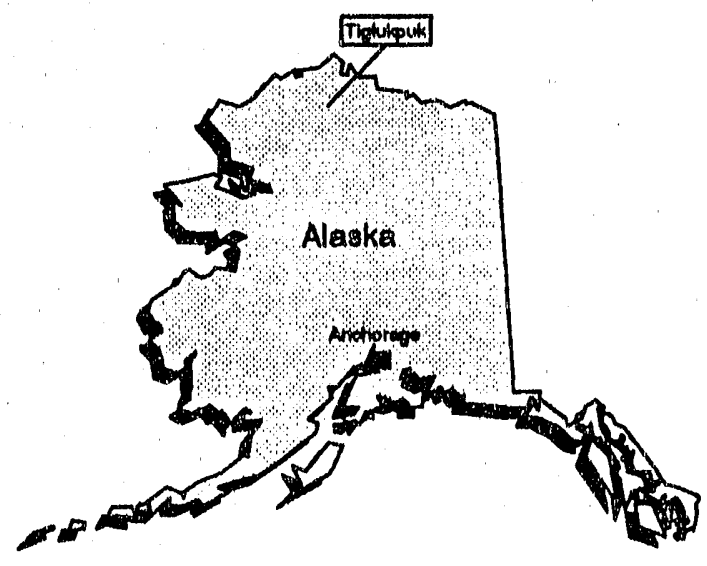

\section{Conversion}

Fischer Assay, wt \% Carbon, wt \% Carbon Conversion, \%

Oil

58.00

84.2

78

Gas

8.80

55.7

8

Residue

26.66

32.5

14

Raw Shale

100.00

62.7

Carbon Balance Fischer Assay

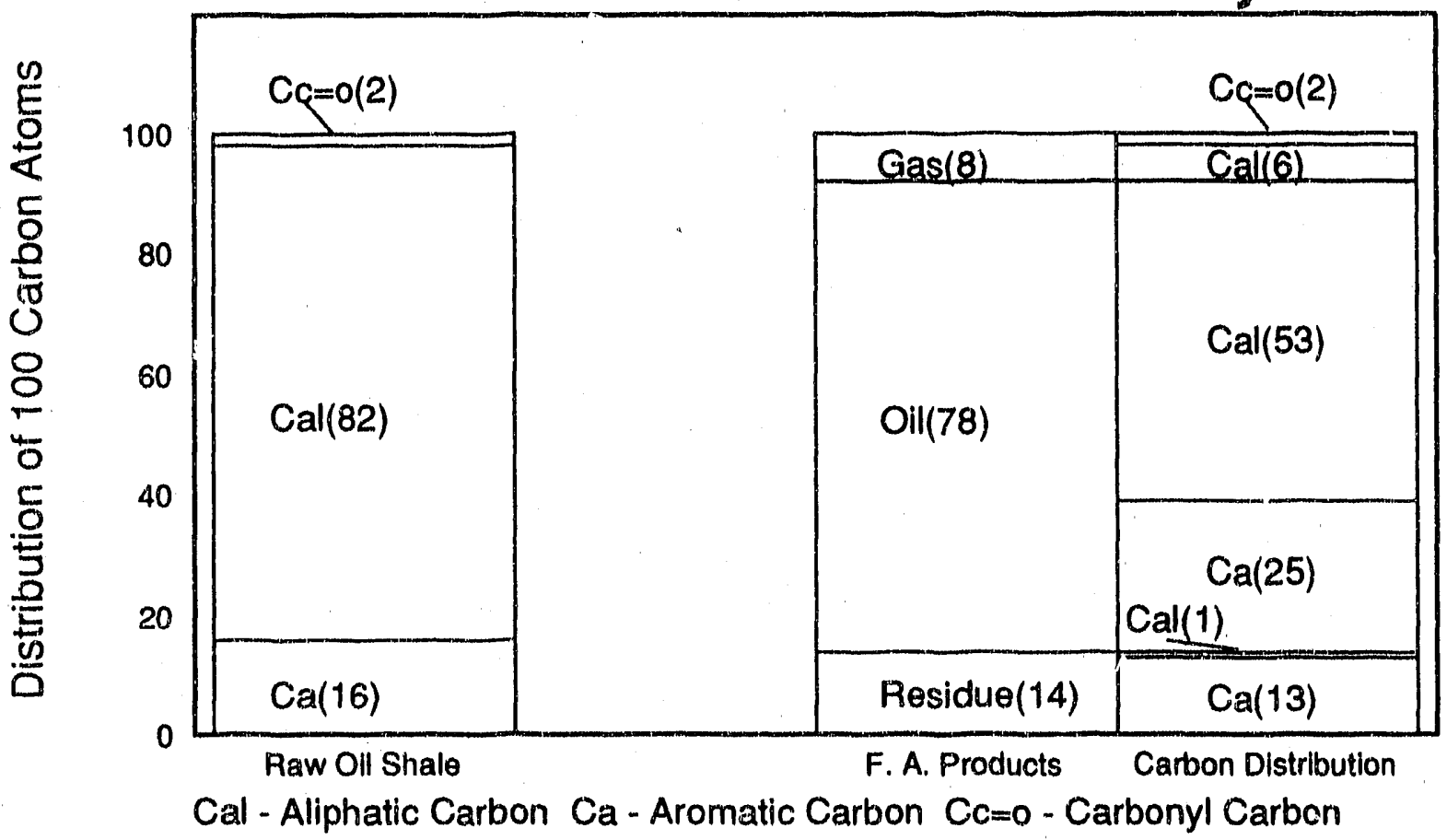




\section{Alaska - Tiglupuk \\ Shale Oil Properies}

$\begin{array}{lrlc}\text { Carbon, wt \% } & 84.2 & \text { Carbon Aromaticity, \% } & 31.9 \\ \text { Hydrogen, wt \% } & 11.9 & \text { Hydrogen Aromaticity, \% } & 7.3 \\ \text { Nitrogen, wt \% } & 0.3 & \text { Whole Oil Molecular Weight } & 310 \\ \text { Sulfur, wt \% } & 0.8 & \text { Specific Gravity } & 0.9101\end{array}$

Totai:i/C 1.70

Aromatic $\mathrm{H} / \mathrm{C} \quad 0.388$

Aliphatic H/C

2.242

Shale Oil NMR Spectra
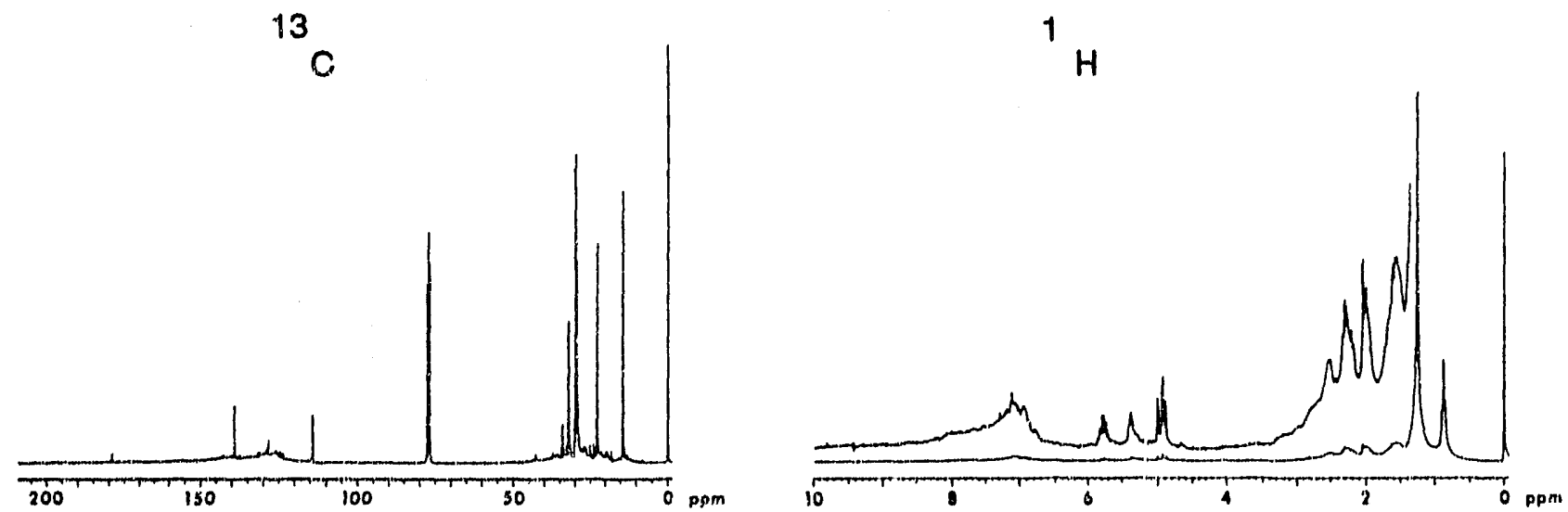

\section{Simulated Distillation of Shale Oil}

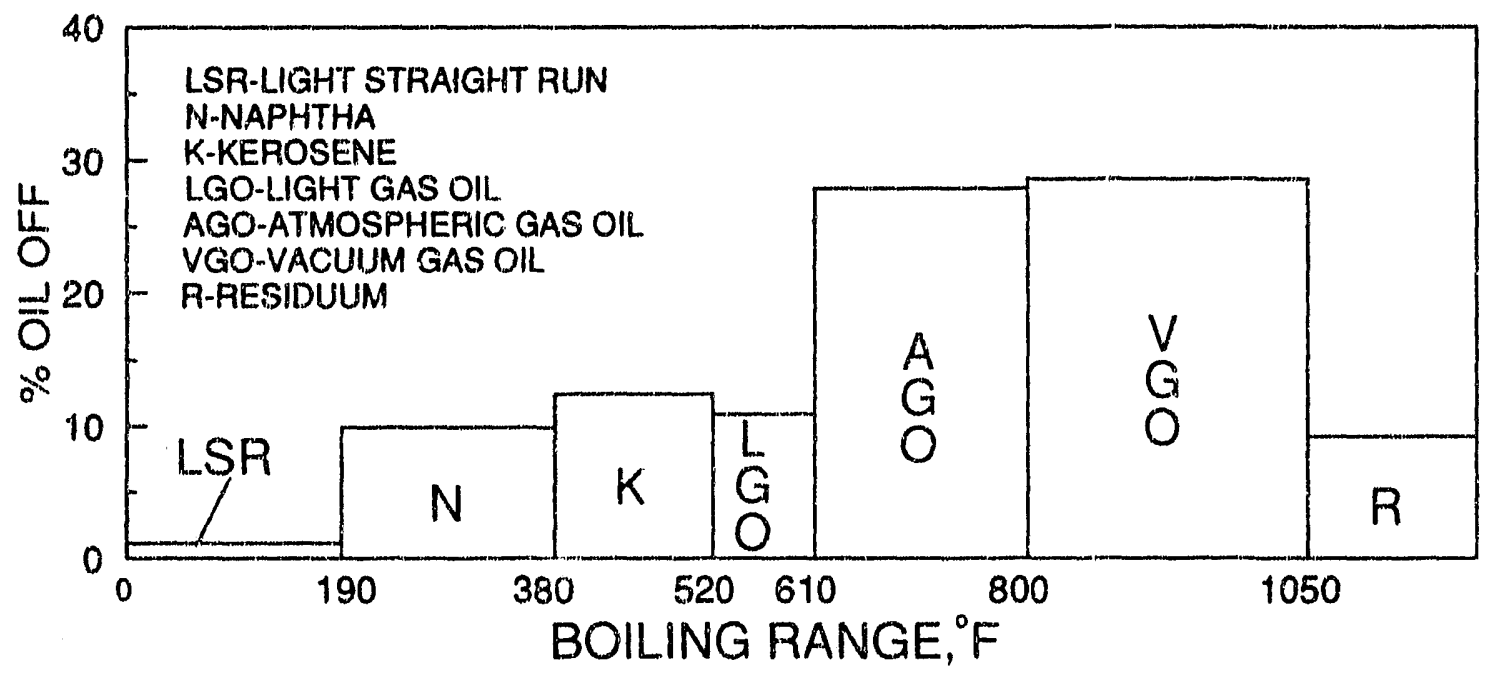


WESTERN RESEARCH INSTITUTE OIL SHALE DATA SHEET

Sample: Stuart oil shale

Geologic Age: Tertiary

Depositional Environment: Lacustrine

F. A. Oil Yield: $31.3 \mathrm{gpt}$

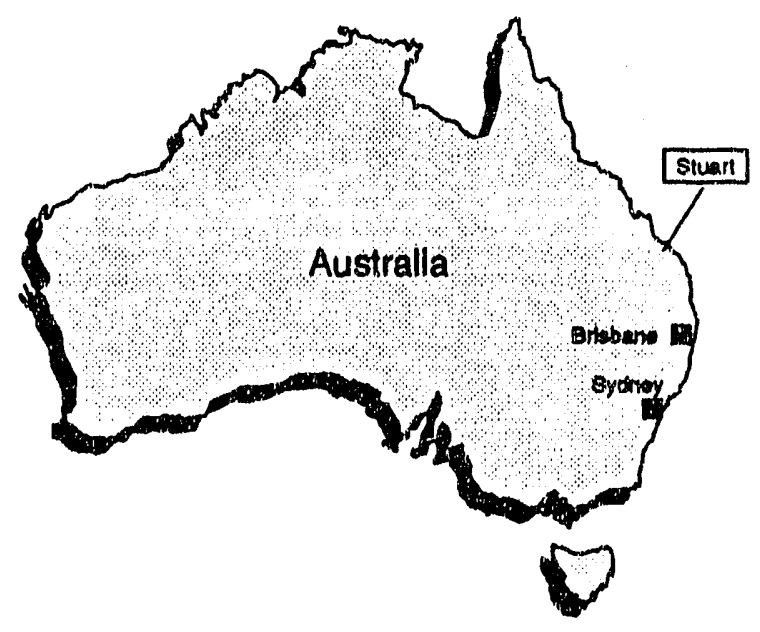

\section{Conversion}

Fischer Assay, wt \% Carbon, wt \% Carbon Conversion, \%

Oil

Gas

Residue

Raw Shale
11.65

3.03

75.77

100.00
81.6

41.6

12.1

15.4
48

6

46

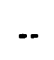

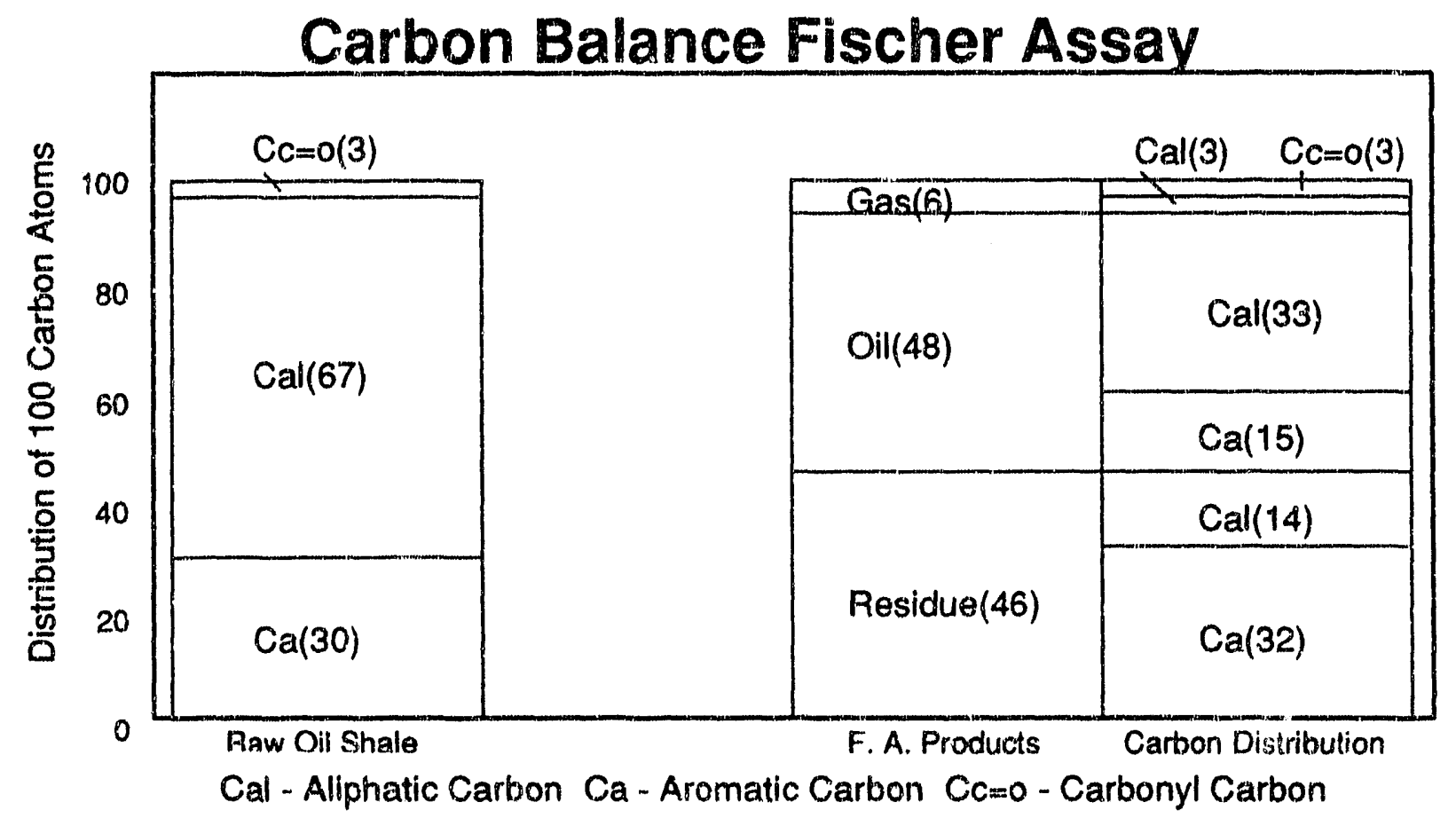




\section{Australia - Stuart \\ Shale Oil Properties}

$\begin{array}{lrlc}\text { Carbon, wt \% } & 81.6 & \text { Carbon Aromaticity, \% } & 29.7 \\ \text { Hydrogen, wt \% } & 12.3 & \text { Hydrogen Aromaticity, \% } & 6.9 \\ \text { Nitrogen, wt \% } & 1.0 & \text { Molecular Weight } & 280 \\ \text { Sulfur, wt \% } & 0.7 & \text { Speciffc Gravity } & 0.8902\end{array}$

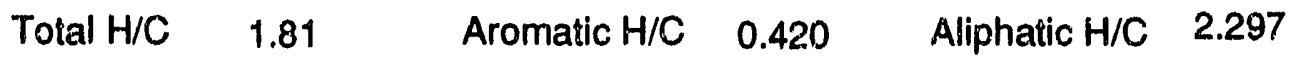

Shale Oil NMR Spectra
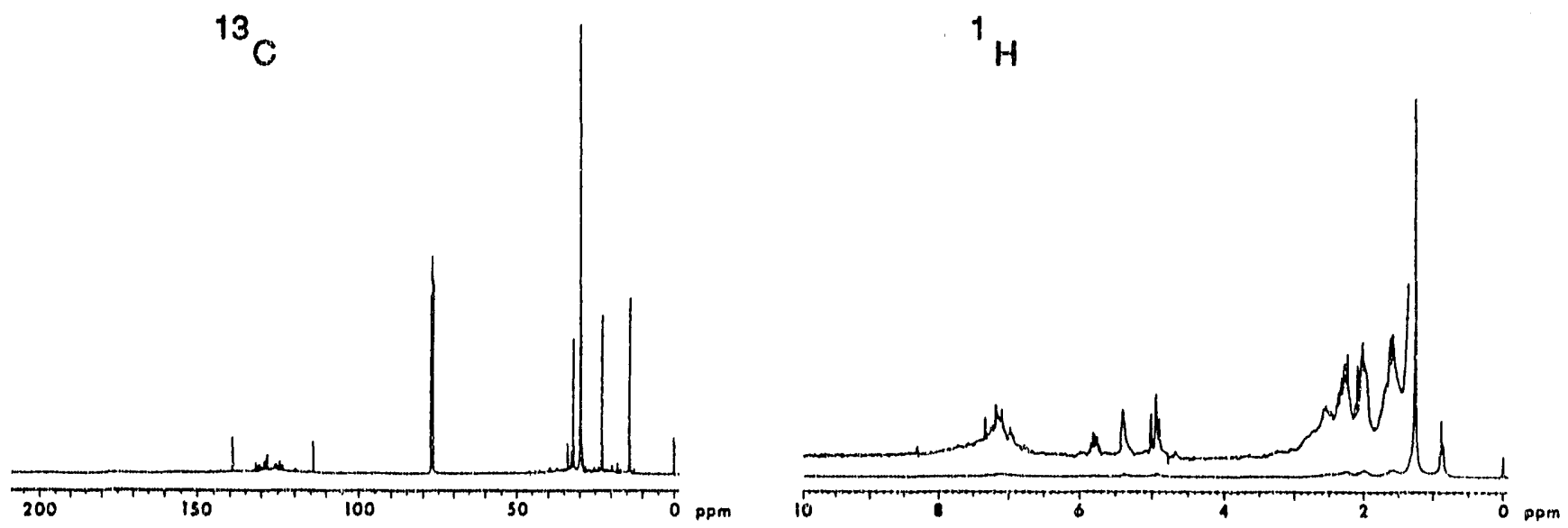

\section{Simulated Distillation of Shale Oil}

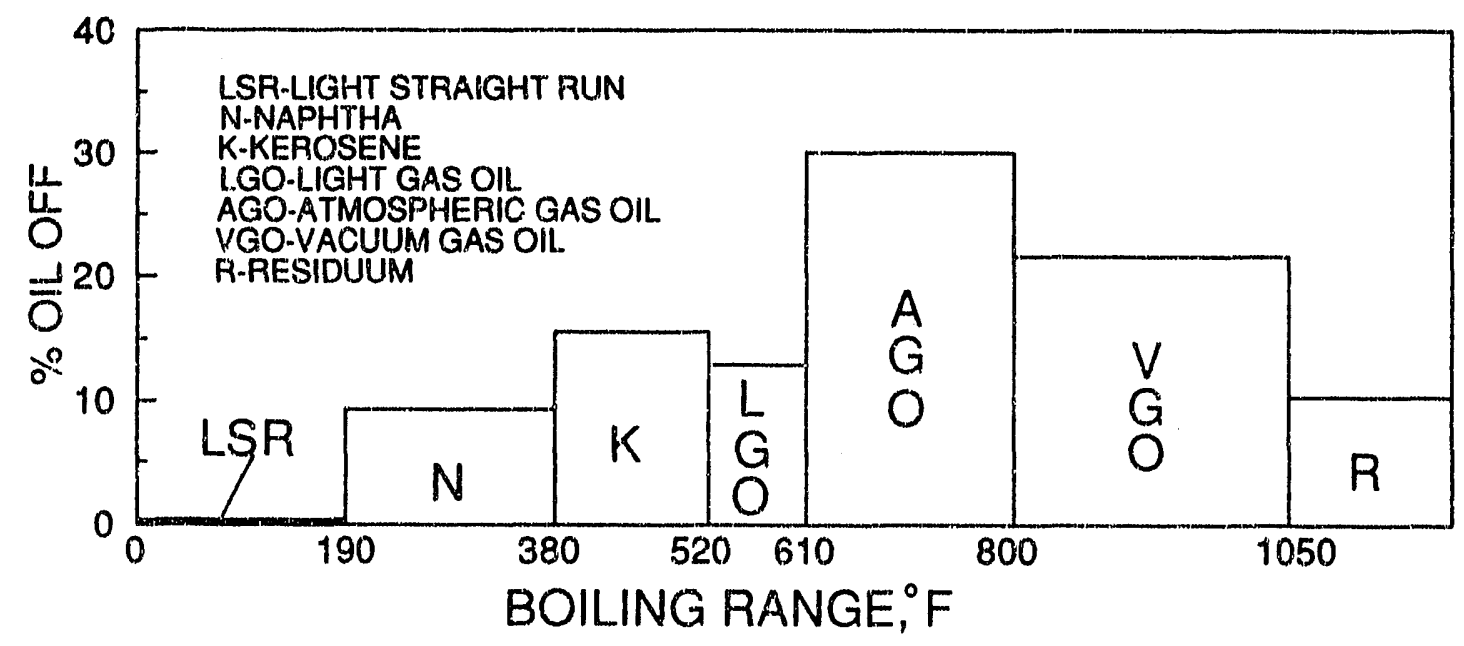


WESTERN RESEARCH INSTITUTE OIL SHALE DATA SHEET

Sample: Irati oil shale

Geologic Age: Permian

Depositional Environment: Marine

F. A. Oil Yield: $28.9 \mathrm{gpt}$

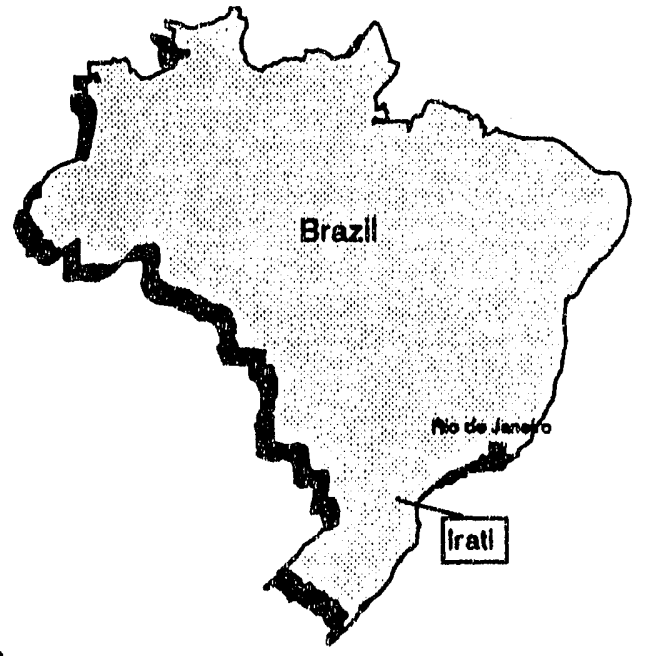

\section{Conversion}

Fischer Assay, wt \% Carbon, wt \% Carbon Conversion, \%

Oil

Gas

Residue

Raw Shale
11.14

2.29

83.22

100.00
83.7

36.0

8.6

17.5
54

5

41

Carbon Balance Fischer Assay

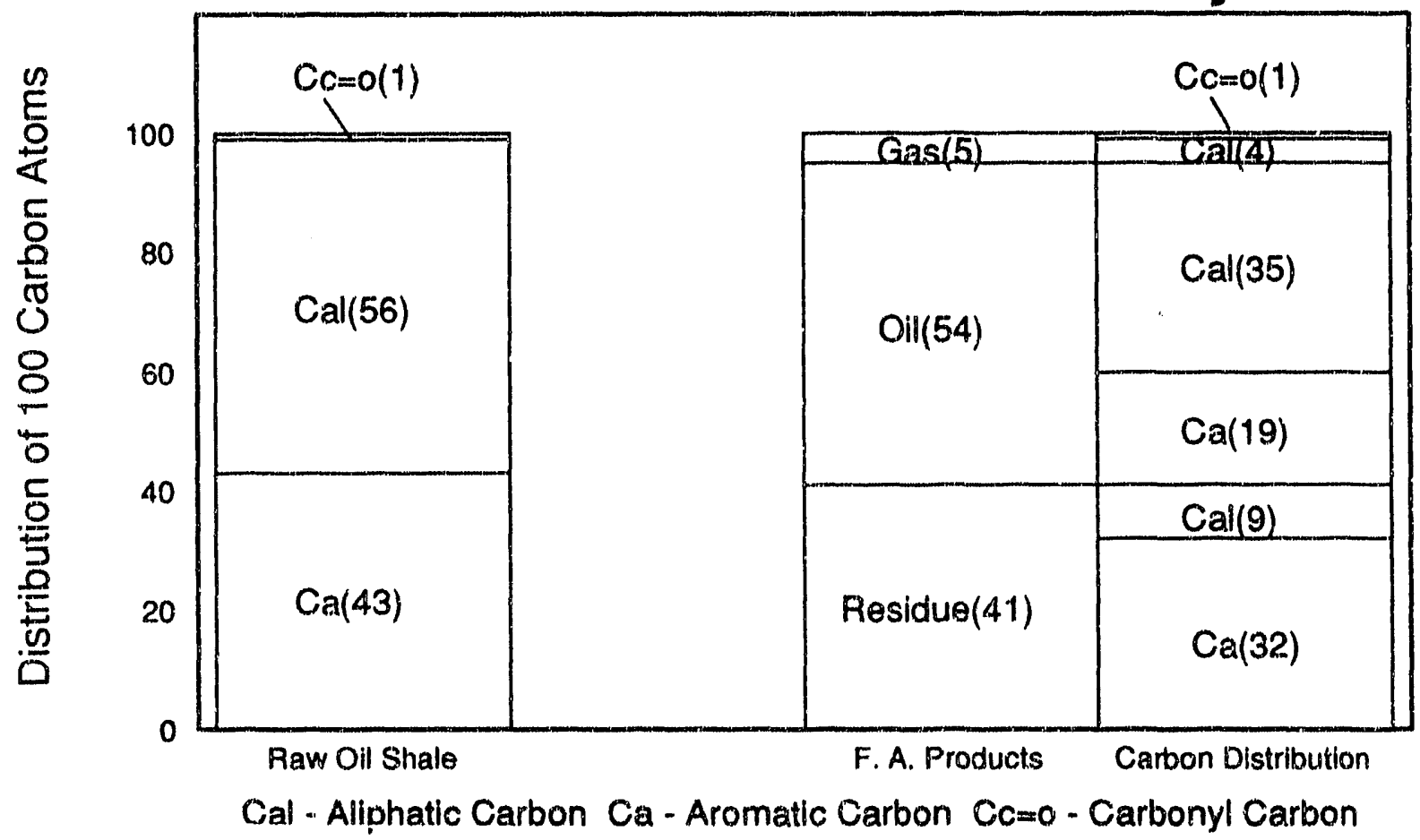




\section{Brazil - Irati \\ Shale Oil Properties}

Carbon, wt \%

83.7

Carbon Aromaticity, \%

35.6

Hydrogen, wt \% 11.2

Nitrogen, wt \%

0.9

Hydrogen Aromaticity, \%

8.0

Sulfur, wt $\%$

1.2

Molecular Weight

300

Specific Gravity

0.9151

Total H/C

Aromatic H/C

0.361

Aliphatic H/C

2.238

Shale Oil NMR Spectra
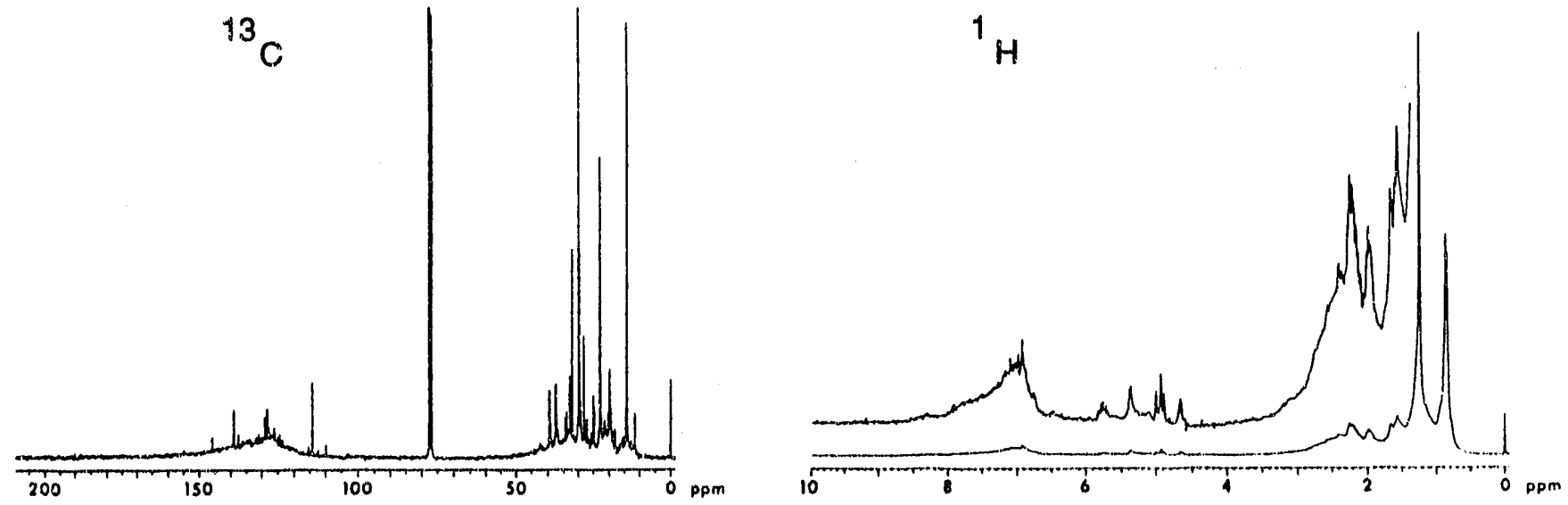

Simulated Distillation of Shale Oil

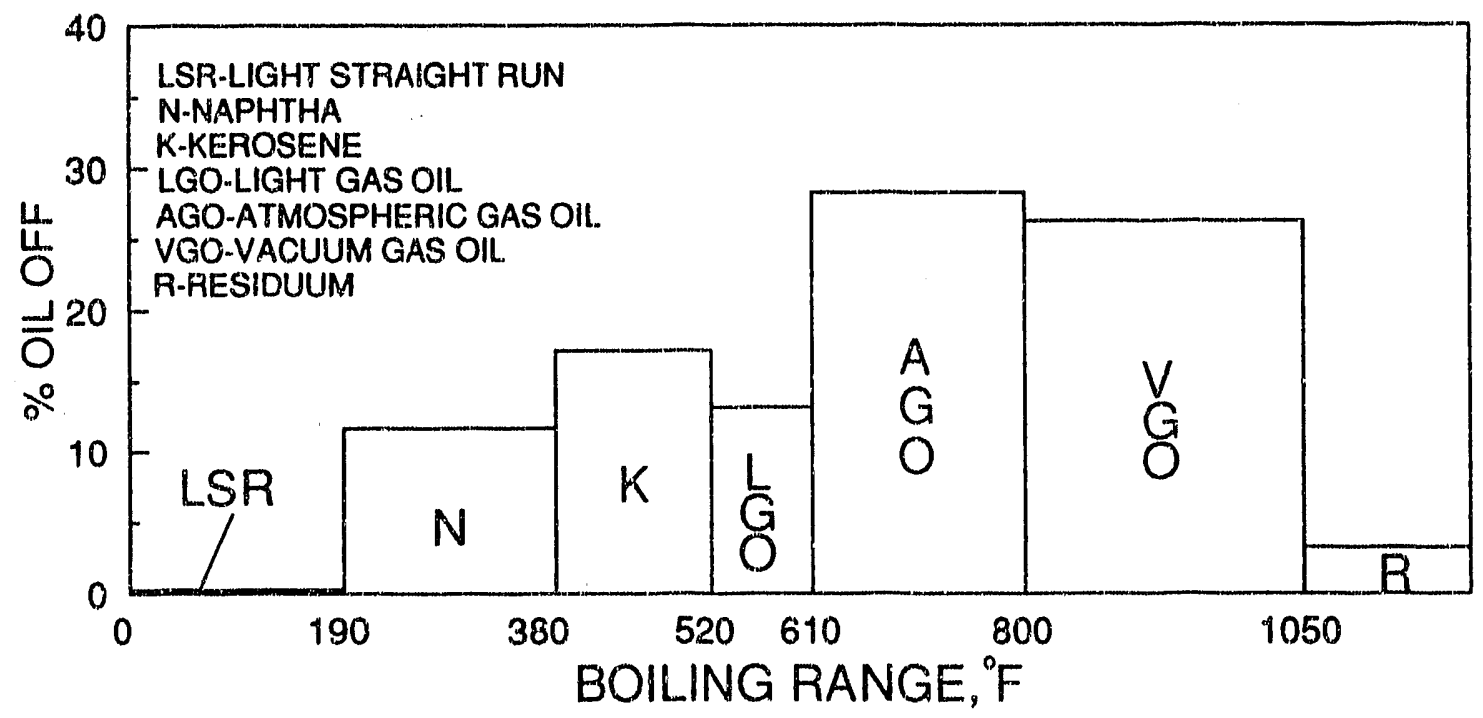


WESTERN RESEARCH INSTITUTE OIL. SHALE DATA SHEET

Sample: Fushun oil shale

Geologic Age: Tertiary

Depositional Environment: Lacustrine

F. A. Oil Yield: $21.6 \mathrm{gpt}$

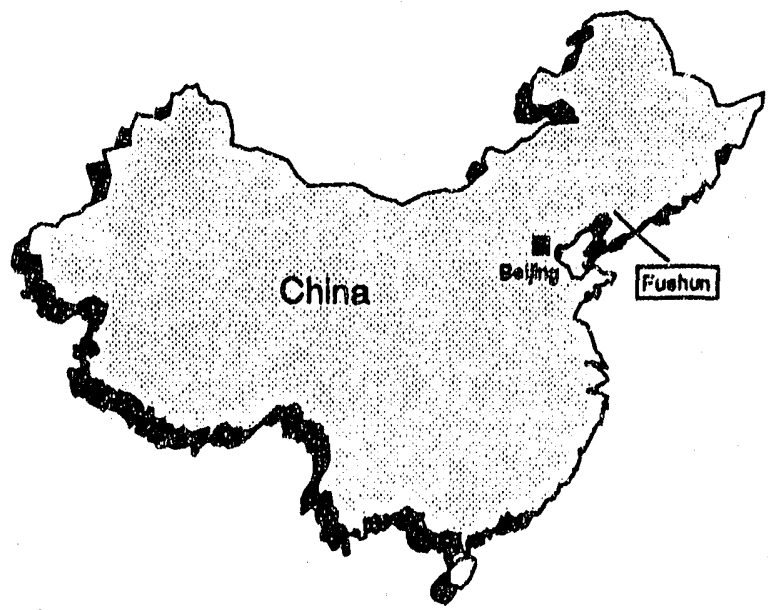

Conversion

Fischer Assay, wt \% Carbon, wt \% Carbon Conversion, \%

Oil

8.01

83.9

53

Gas

2.29

43.5

8

Residue

83.98

6.0

39

Raw Shale

100.00

13.0

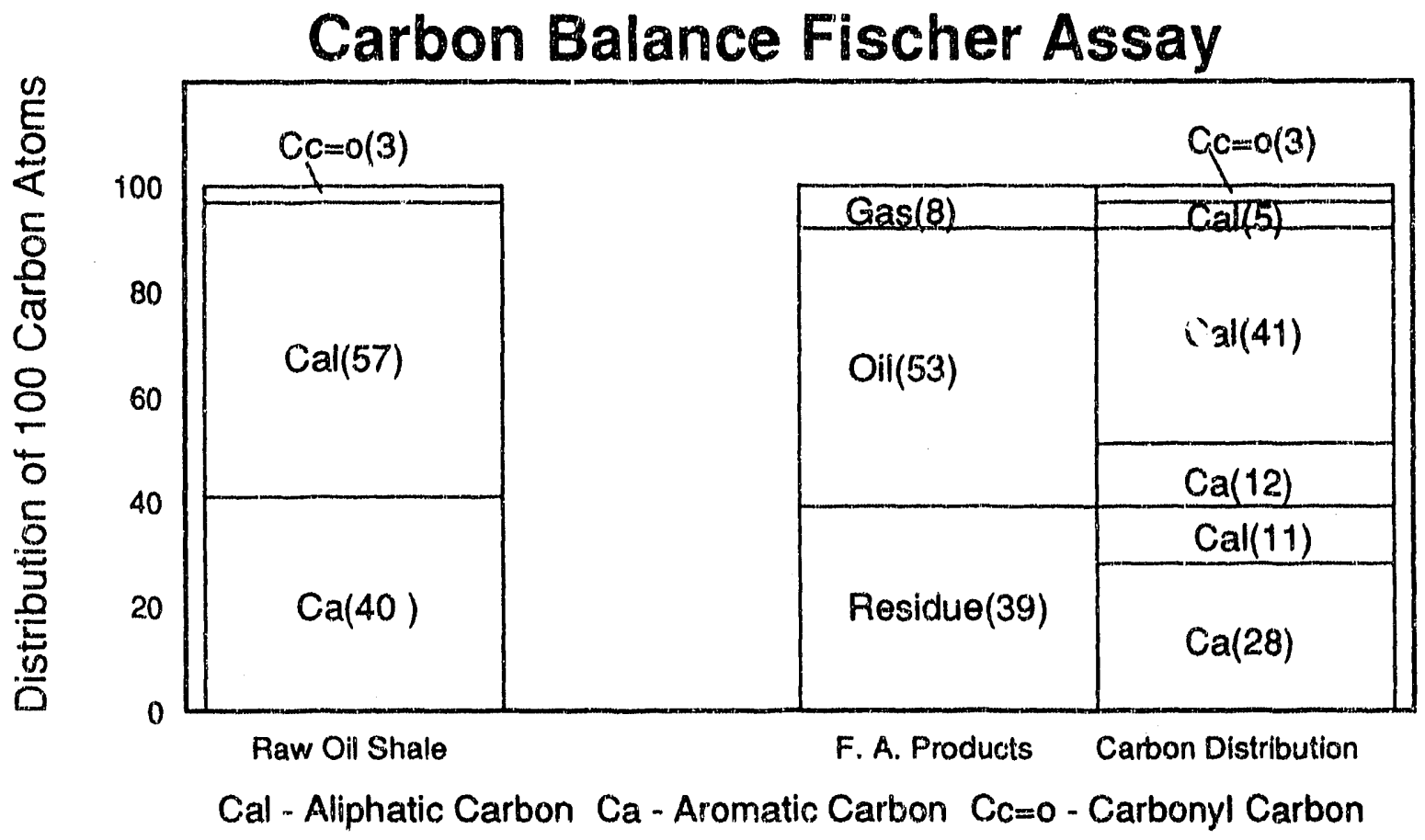




\section{Crina - Fushun \\ Shale Oil Properties}

$\begin{array}{lrlc}\text { Carbon, wt \% } & 83.9 & \text { Carbon Aromaticity, \% } & 22.2 \\ \text { Hydrogen, wt \% } & 12.2 & \text { Hydrogen Aromaticity, \% } & 5.8 \\ \text { Nitrogen, wt \% } & 2.2 & \text { Molecular Weight } & 300 \\ \text { Sulfur, wt \% } & 0.7 & \text { Specific Gravity } & 0.8873\end{array}$

Total H/C 1.75 Aromatic H/C 0.456 Aliphatic H/C 2.040

\section{Shale Oil NMR Spectra}
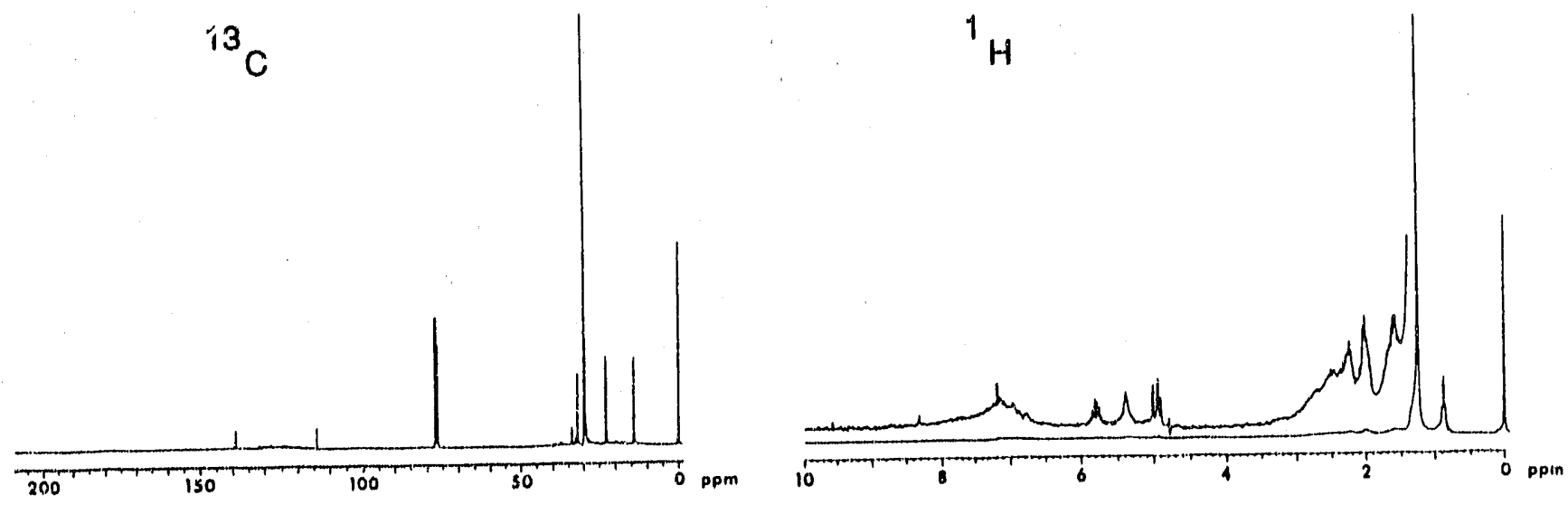

\section{Simulated Distillation of Shale Oil}

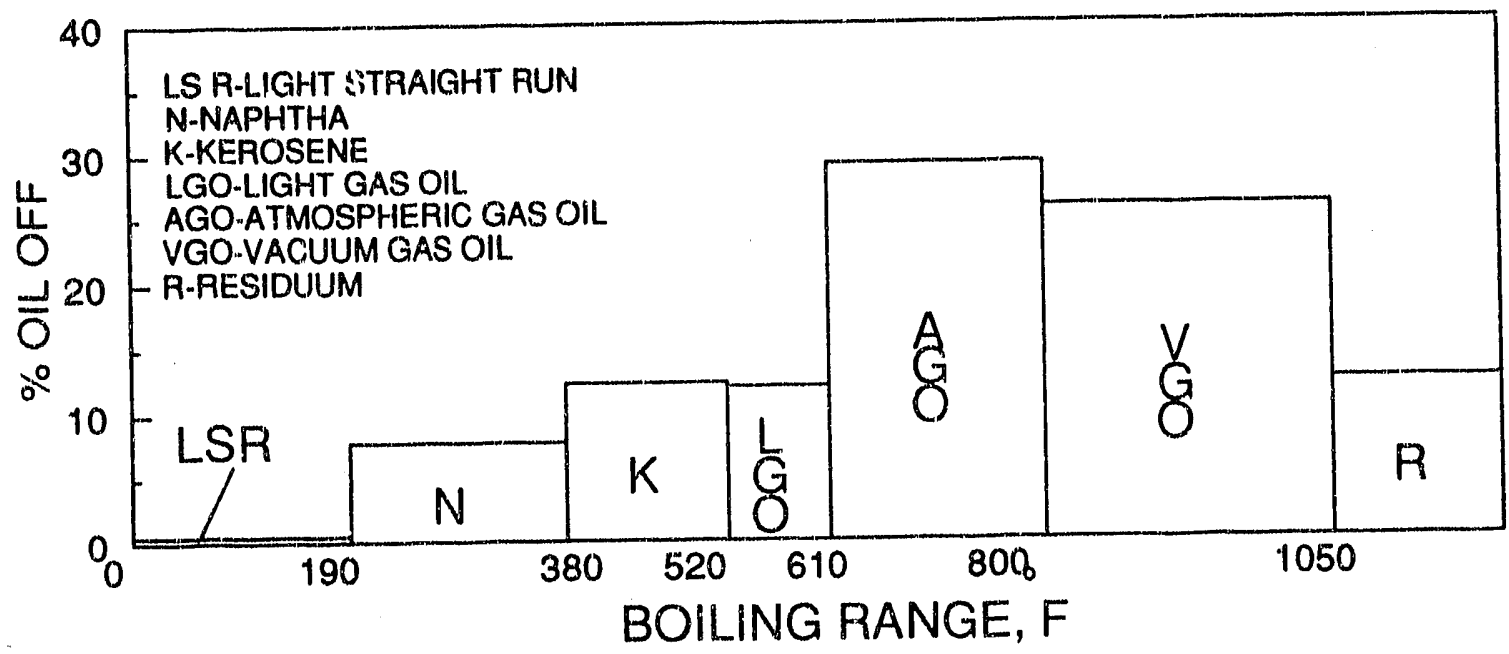




\section{WESTERN RESEARCH INSTITUTE OIL SHALE DATA SHEET}

Sample: Maoming oil shale

Geologic Age: Tertiary

Depositional Environrnent: Lacustrine

F. A. Oil Yiold: $20.5 \mathrm{gpt}$

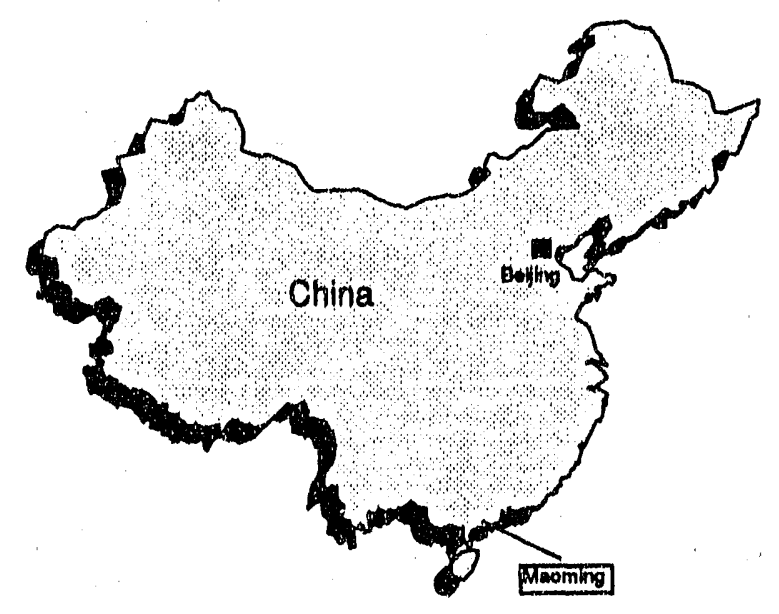

\section{Conversion}

Fischer Assay, wt \% Carbon, wt \% Carbon Conversion, \%

Oil

Gas

Residue

Raw Shale
7.71

2.70

83.11

100.00
85.4

42.7

8.8

15.4
44

8

48

Carbon Balance Fischer Assay

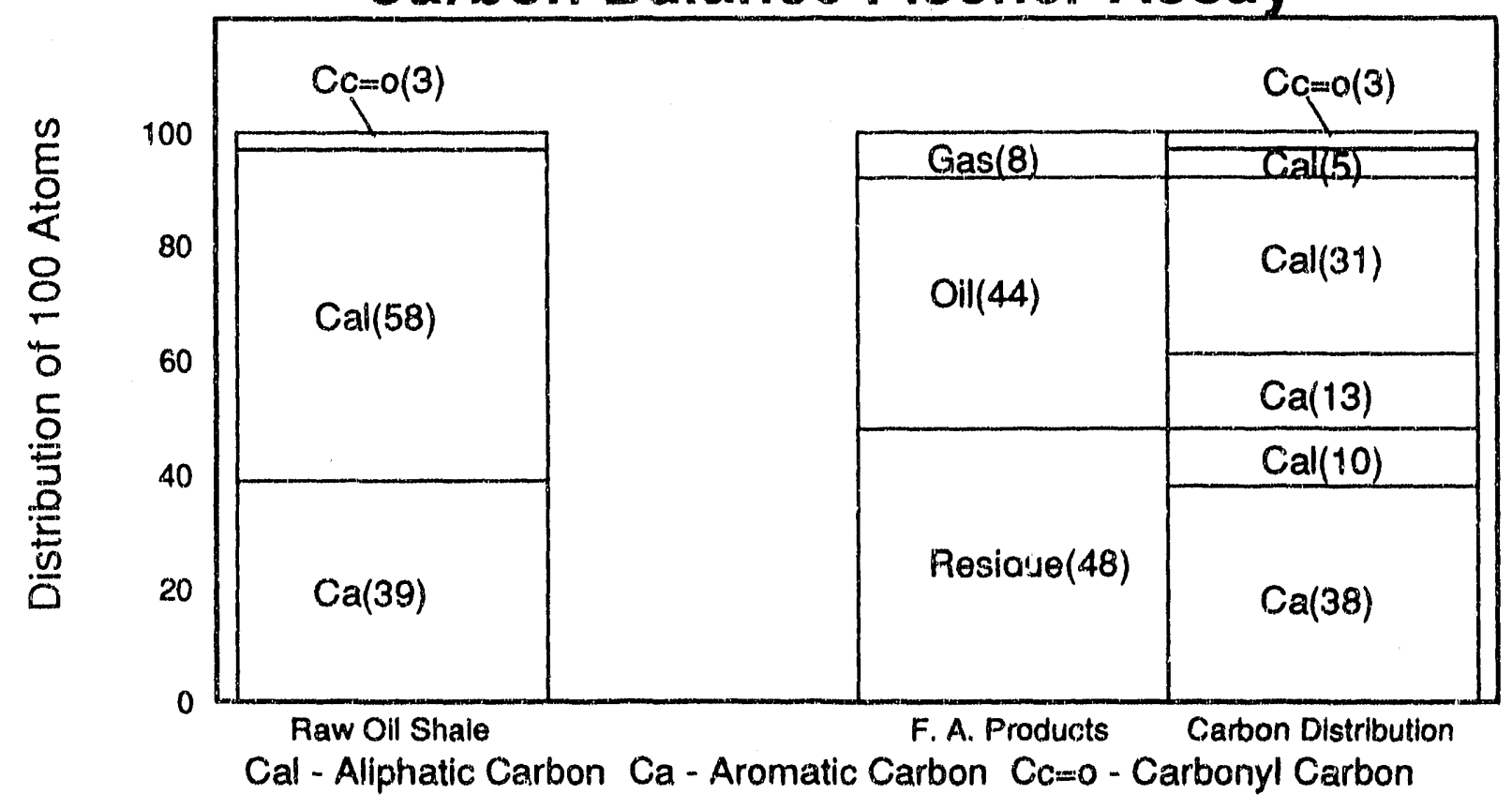




\section{China - Maoming \\ Shale Oil Properties}

Carbon, wt \% 85.5

Hydrogen, wt \% 12.2

Nitrogen, wt \% 1.2

Sulfur, wt \% $\quad 0.6$

Total H/C 1.71
Carbon Aromaticity, \%

Hydrogen Aromaticity, \%

Molecular Weight

Specific Gravity
30.1

6.4

300

0.9002

Aromatic H/C $0.364 \quad$ Aliphatic H/C 2.209

\section{Shale Oil NMR Spectra}

${ }^{13} \mathrm{C}$

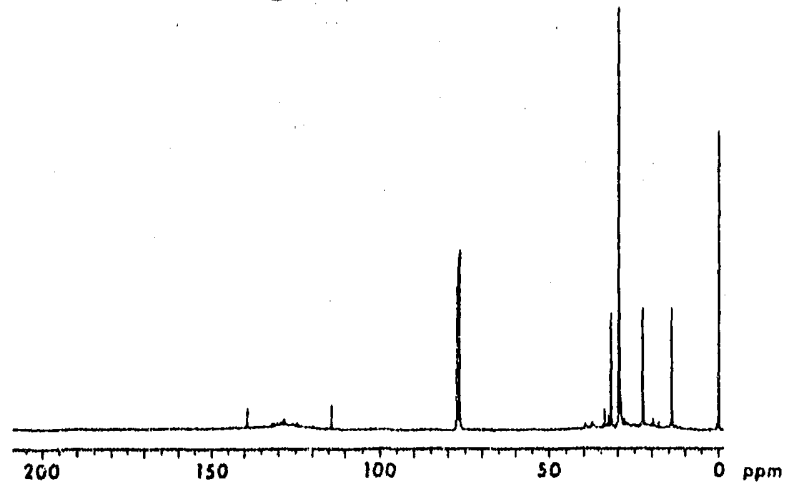

$1 \mathrm{H}$

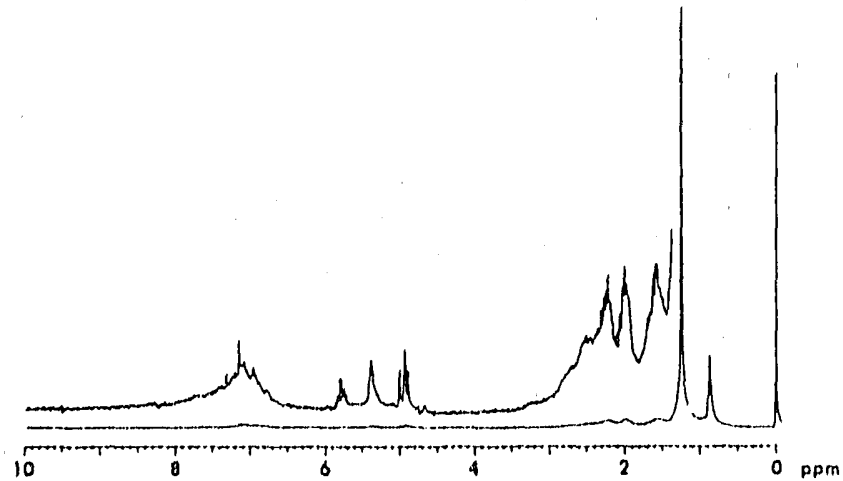

\section{Simulated Distillation of Shale Oil}

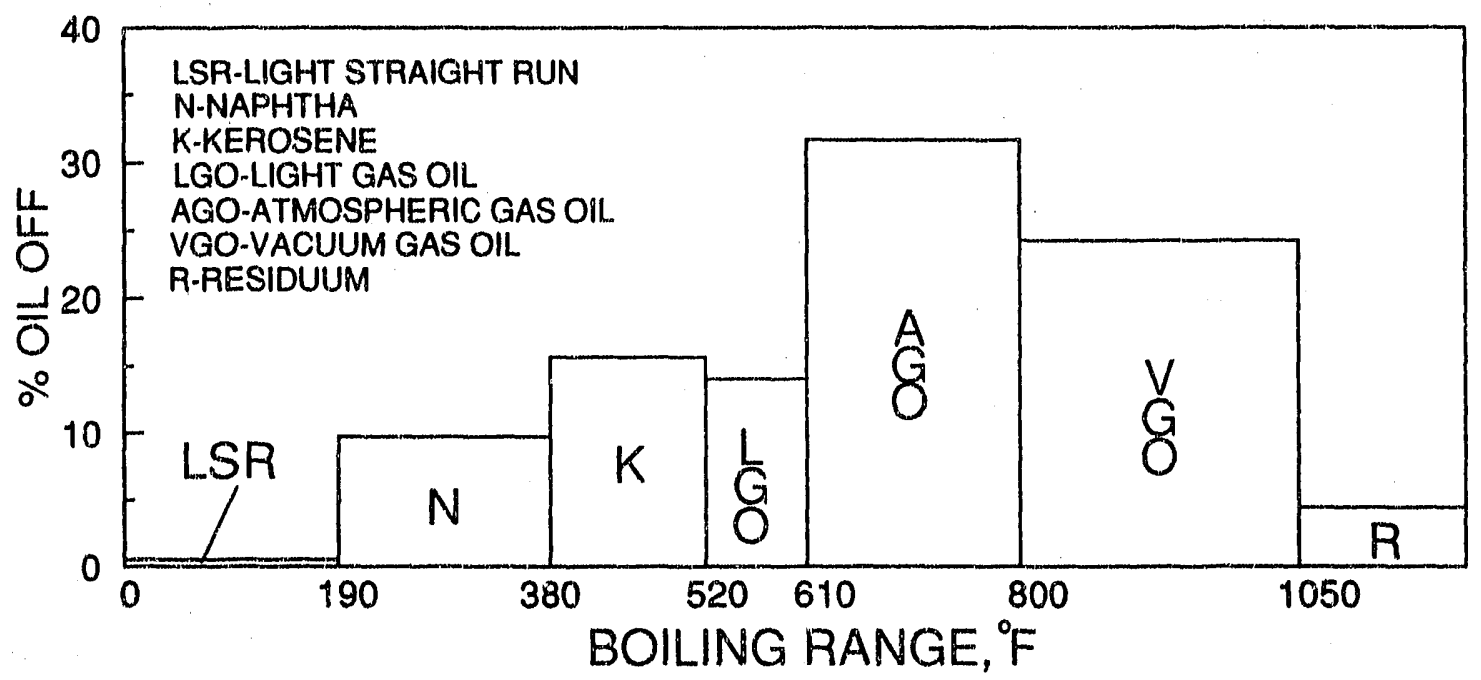


WESTERN RESEARCH INSTITUTE OIL SHALE DATA SHEET

Sample: Anvil Points oil shale

Geologic Age: Tertiary

Depositional Environment: Lacustrine

F. A. Oil Yield: $32.1 \mathrm{gpt}$

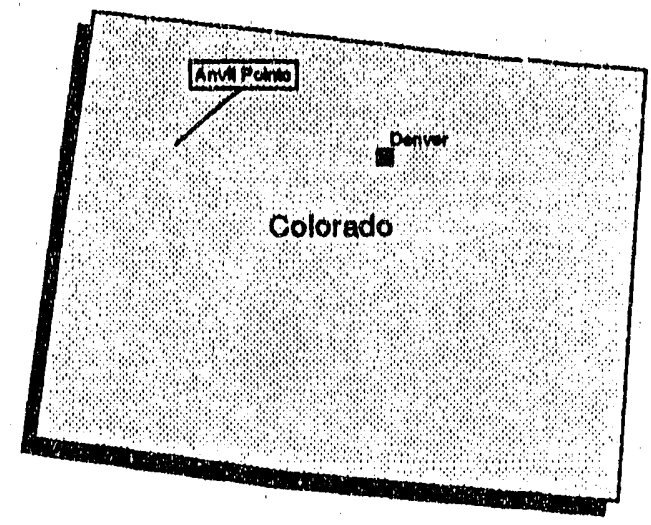

\section{Conversion}

Fischer Assay, wt \% Carbon, wt \% Carbon Conversion, \%

Oil

12.19

83.5

66

Gas

1.59

46.1

5

Residue

84.94

5.3

29

Raw Shale

100.00

14.4

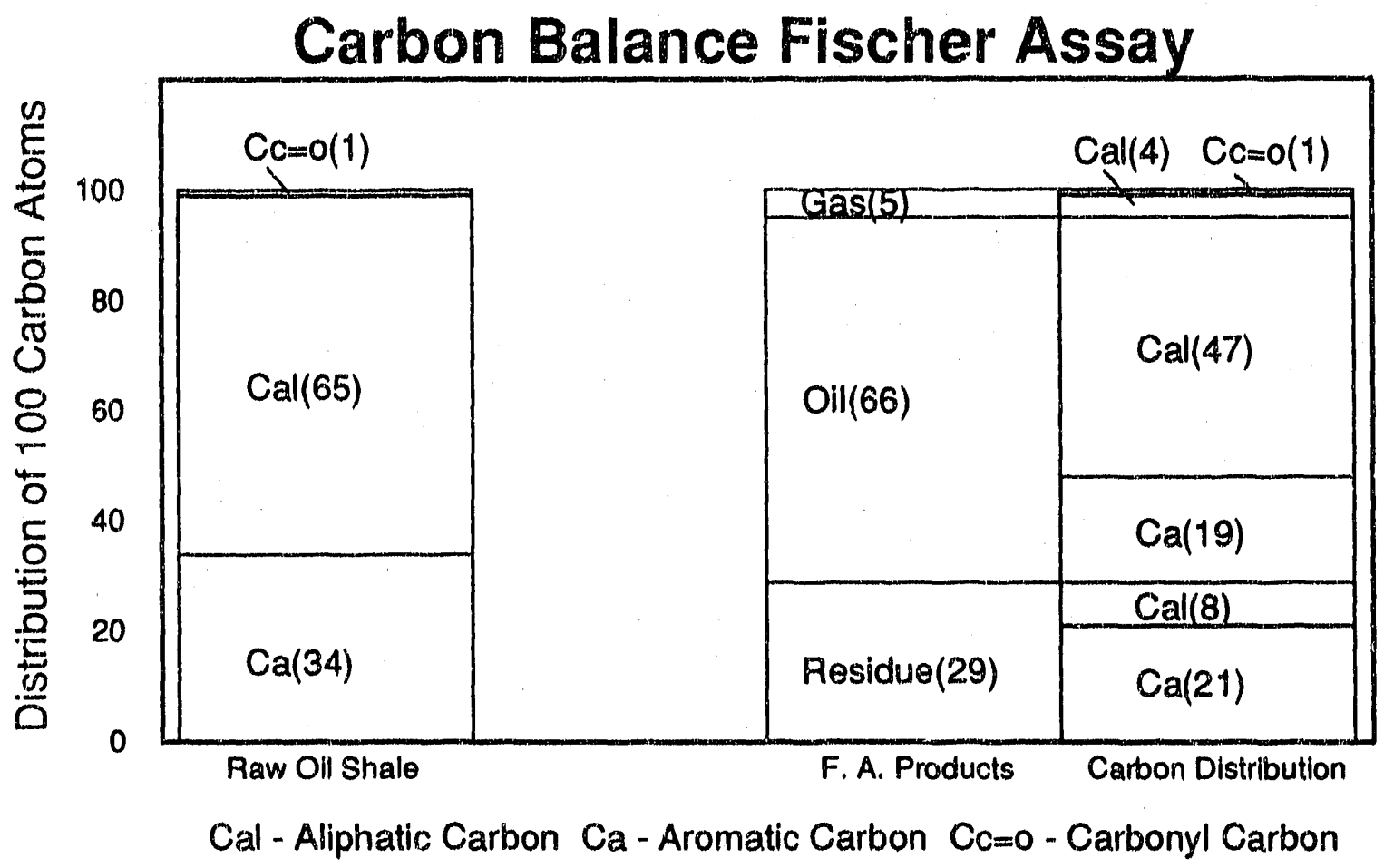


Colorado - Anvil Points

Shale Oil Properties

Carbon, wt \%

83.6

Hydrogen, wt \% 12.2

Nitrogen, wt \%

1.9

Sulfur, wt \%

0.7

Carbon Aromaticity, \%

28.4

Hydrogen Aromatlcity, \%

4.9

Molecular Weight

310

Specific Gravity

0.9091

Total H/C $\quad 1.75$

Aromatic H/C $\quad 0.302$

Aliphatic H/C

2.260

Shale Oil NMR Spectra
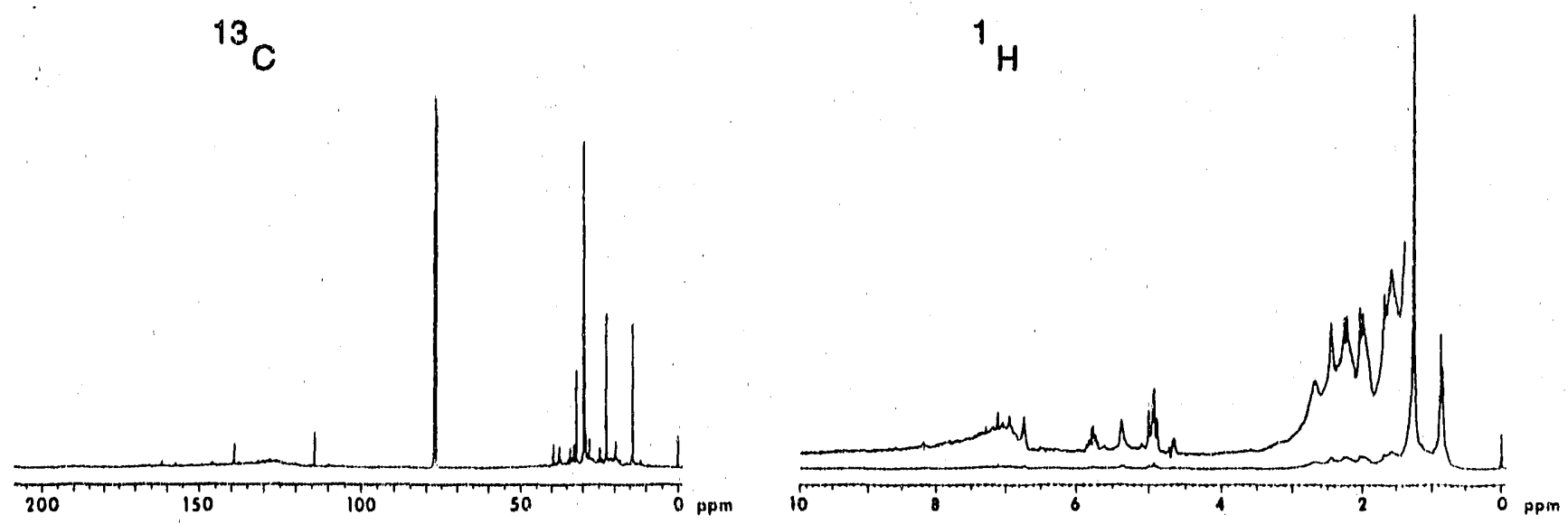

\section{Simulated Distillation of Shale Oil}

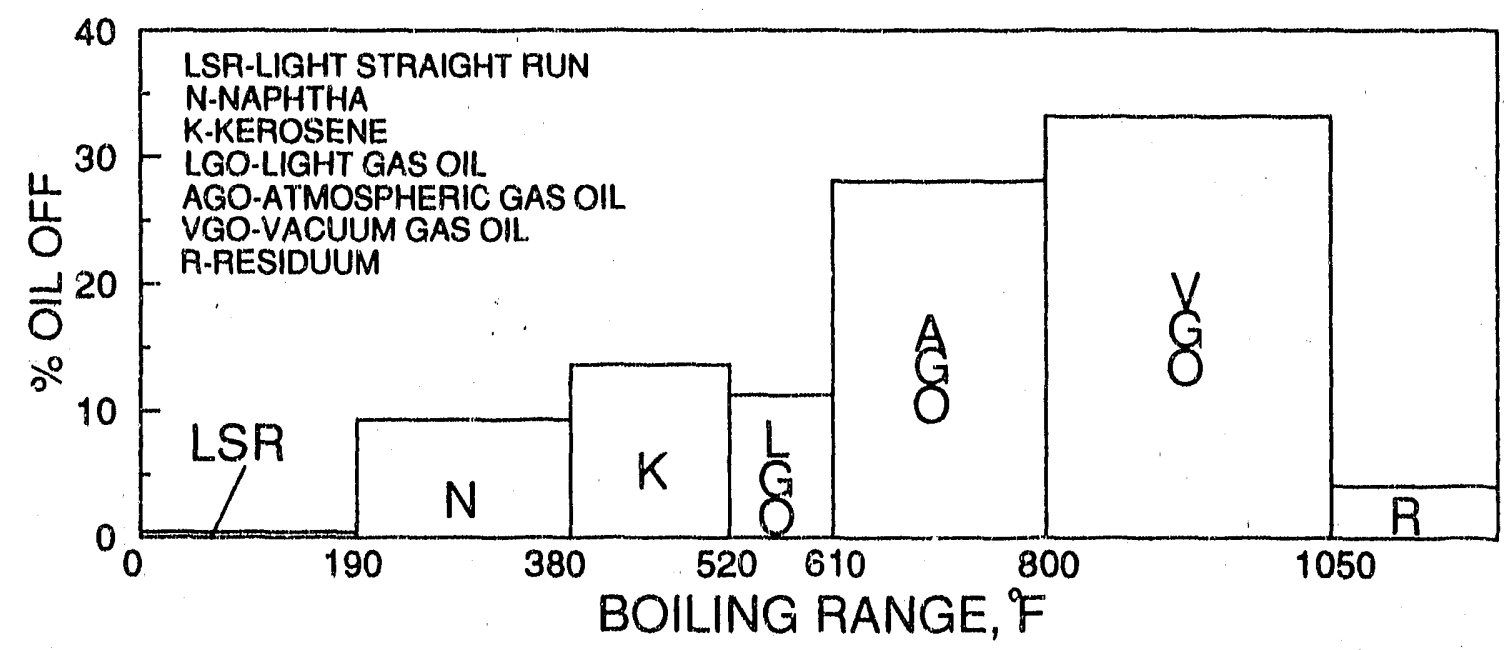




\section{WESTERN RESEARCH INSTITUTE OIL SHALE DATA SHEET}

Sample: Sunbury oil shale

Geologic Age: Mississippian

Depositional Environment: Marine

F. A. Oil Yield: $13.0 \mathrm{gpt}$

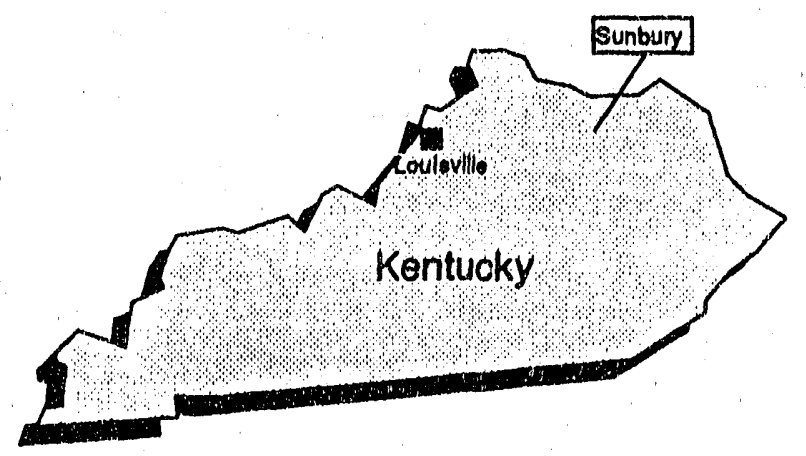

\section{Conversion}

Fischer Assay, wt \% Carbon, wt \% Carbon Conversion, \%

Oil

5.31

83.4

28

Gas

2.76

36.5

6

Residue

88.08

11.8

66

Raw Shale

100.00

16.2

Carbon Balance Fischer Assay

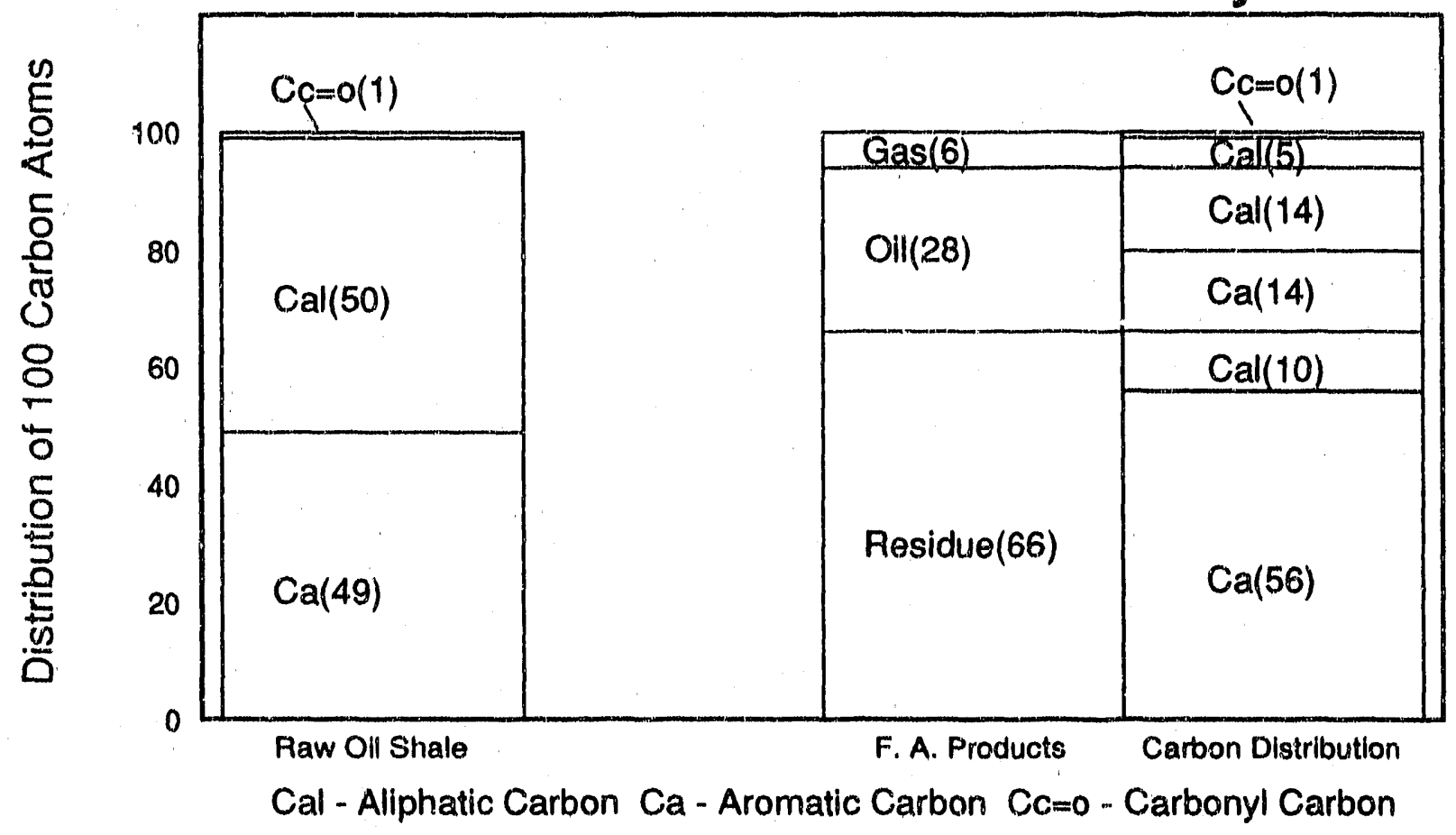




\section{Kentucky - Sunbury \\ Shale Oil Properties}

Carbon, wt \% 83.4

Hydrogen, wt \% 10.0

Nitrogen, wt \%

Sulfur, wt \%

Total H/C $\quad 1.44$
1.1

2.8
Carbon Aromaticity, \%

Hydrogen Aromaticity, \%

Molecular Weight

Specific Gravity
49.5

13.5

280

0.9770

\section{Shale Oil NMR Spectra}
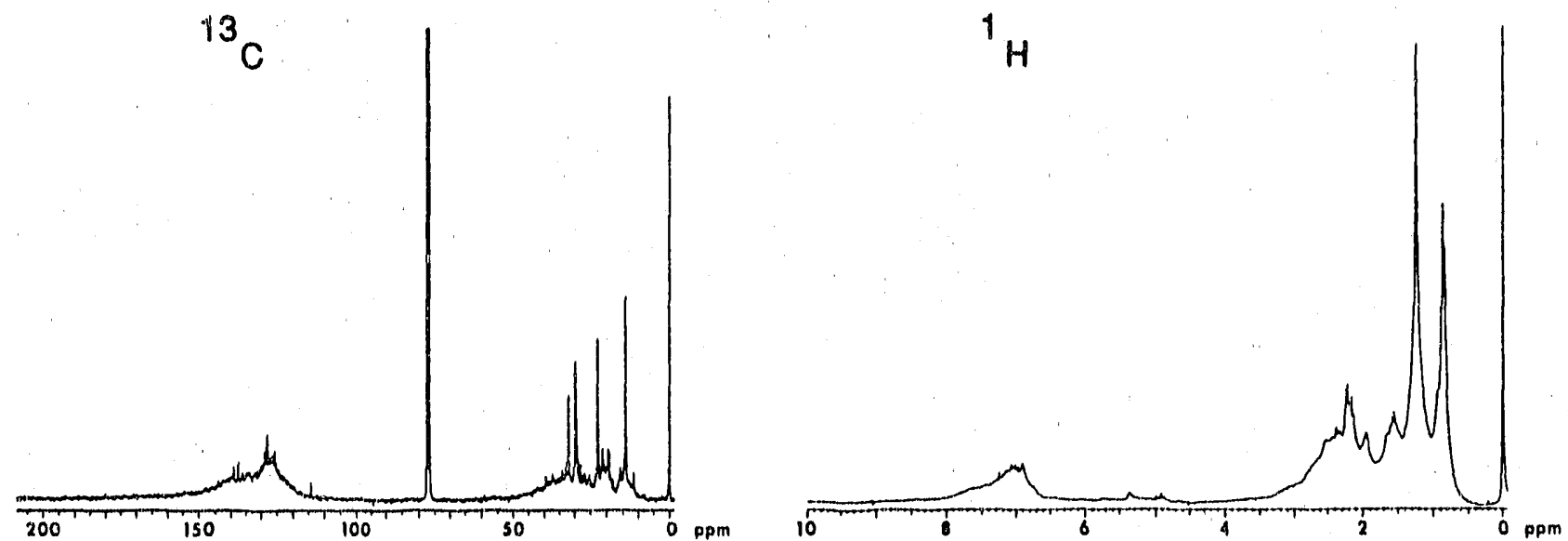

\section{Simulated Distillation of Shale Oil}

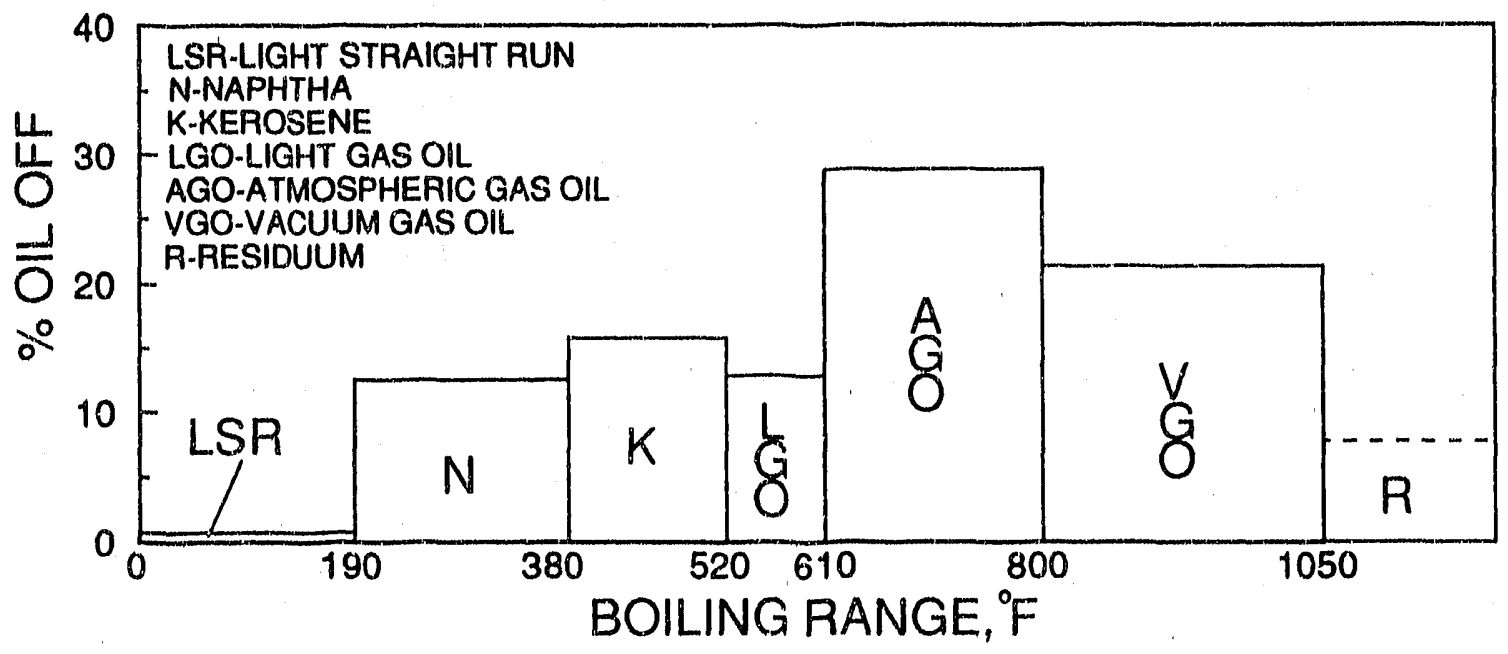


Sample: Timahdit oil shale

Geologic Age: Cretacious

Depositional Environment: Not Determined

F. A. Oil Yield: $11.2 \mathrm{gpt}$

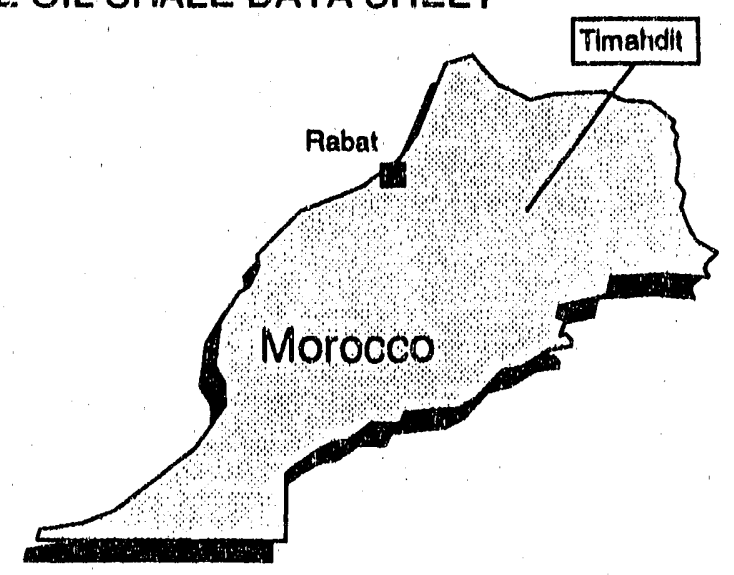

\section{Conversion}

Fischer Assay, wt \% Carbon, wt \% Carbon Conversion, $\%$

Oil

Gas

Residue

Raw Shale
4.57

1.88

90.71

100.00
79.2

30.4

4.5

8.1
44

7

49

Carbon Balance Fischer Assay

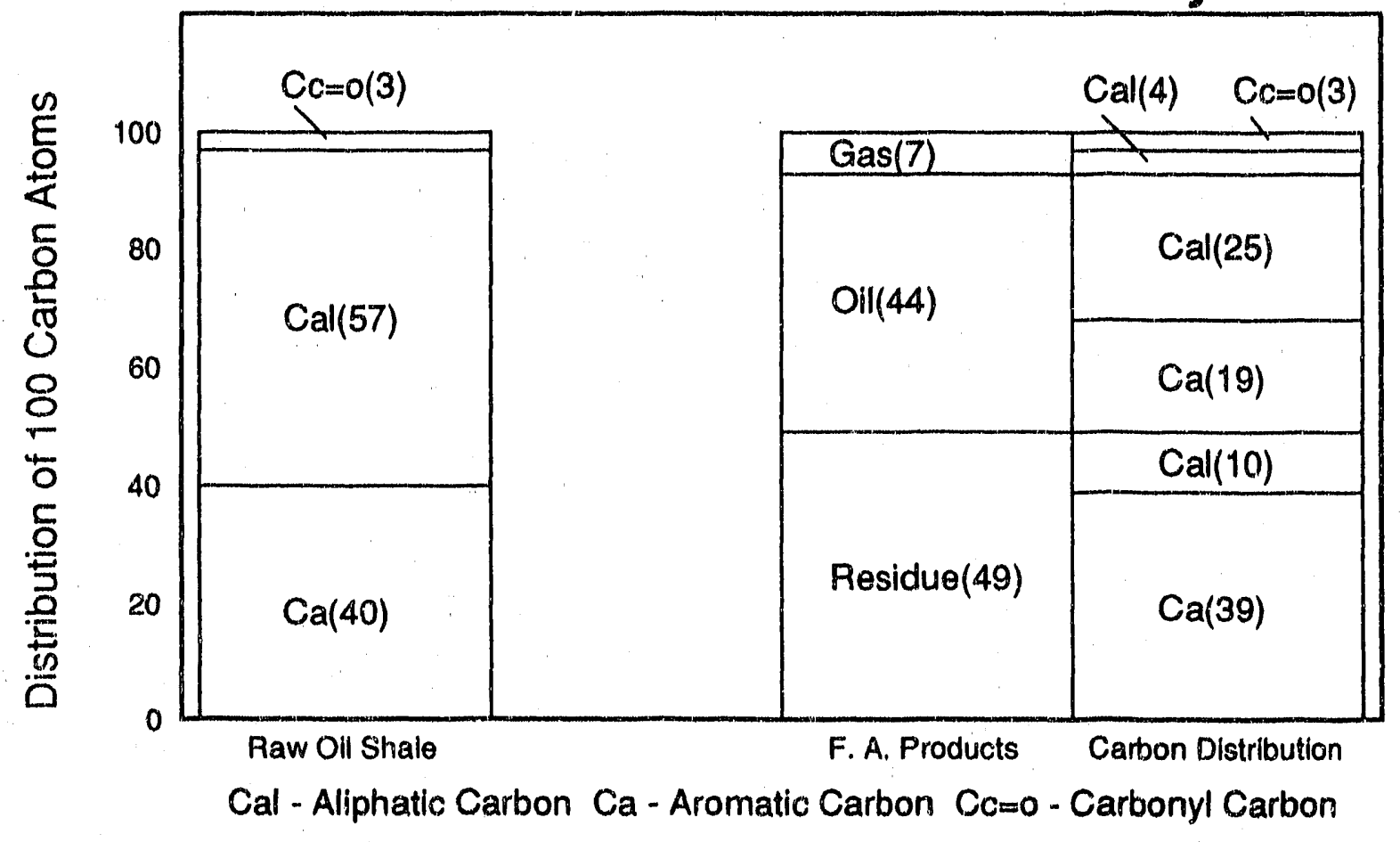




\section{Morocco - Timahdit \\ Shale Oil Properties}

Carbon, wt \% 78.7

Hydrogen, wt \% 10.0

Nitrogen, wt \% 1.4

Sulfur, wt $\% \quad 7.8$

Total H/C $\quad 1.53$
Carbon Aromaticity, \%

Hydrogen Aromaticity, \% Molecular Weight

Specific Gravity
42.2

11.0

270

0.9819

Aromatic H/C $\quad 0.397 \quad$ Allphatic H/C 2.290

Shale Oil NMR Spectra
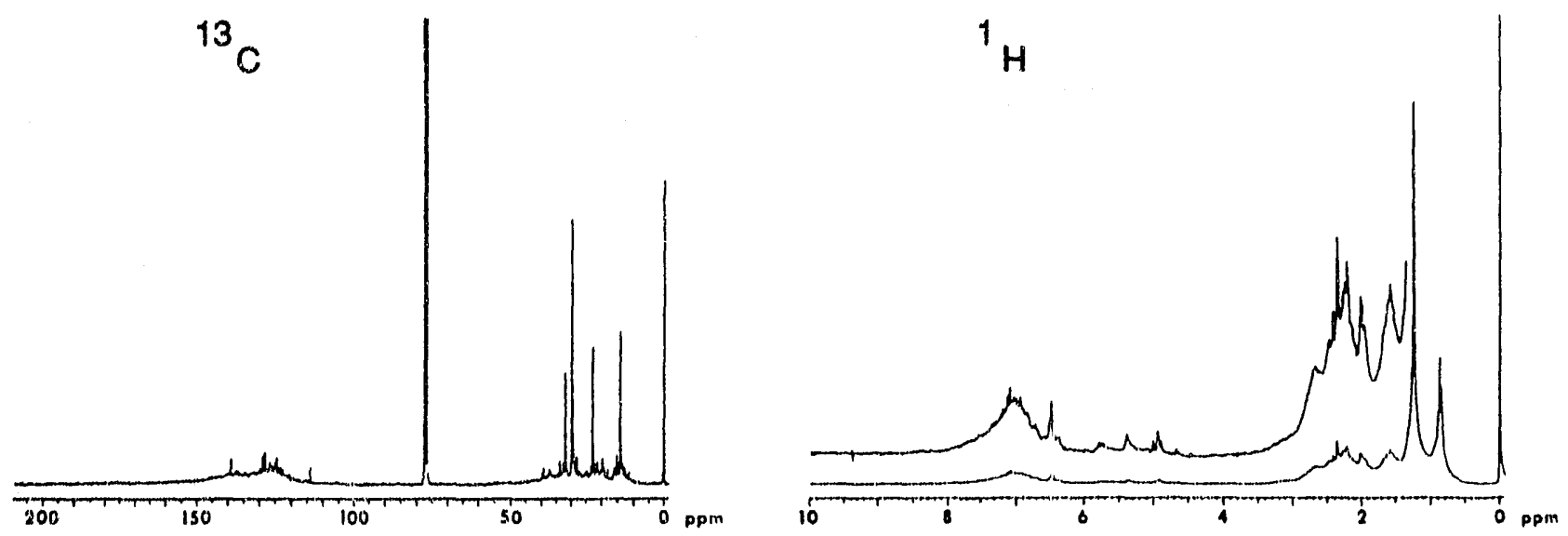

\section{simulated Distillation of Shale Oil}

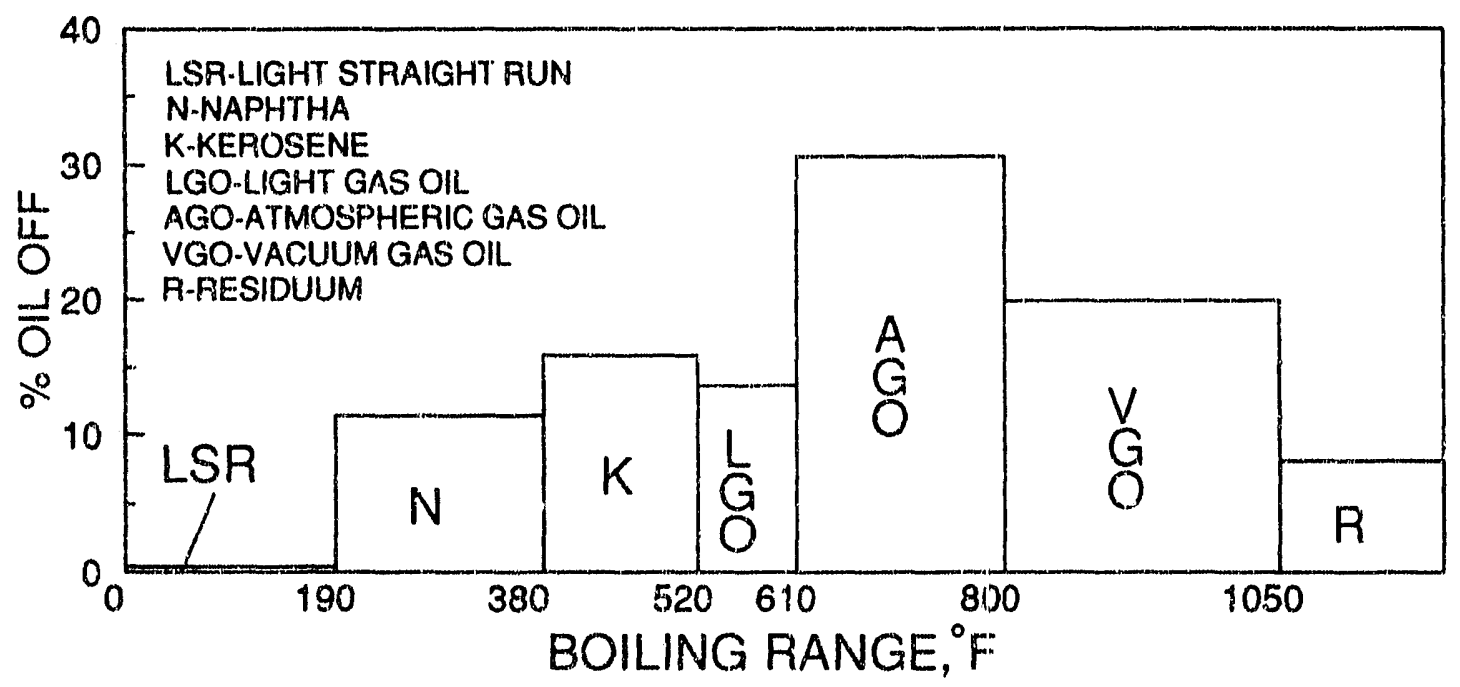




\section{WESTERN RESEARCH INSTITUTE OIL SHALE DATA SHEET}

Sample: Göyrïuk oil shale

Geologic Age: Unknown

Depositional Environment: Unknown

F. A. Oil Yield: $100.3 \mathrm{gpt}$

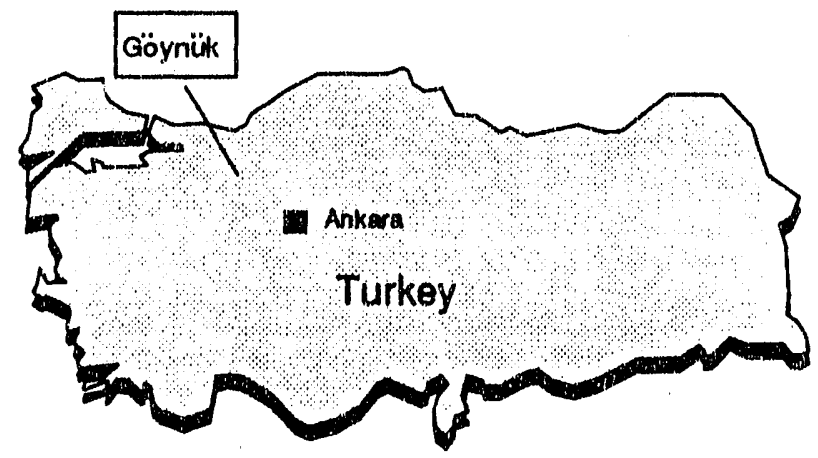

\section{Conversion}

Fischer Assay, wt \% Carbon, wt \% Carbon Conversion, \%

Oil

Gas

Residue

Raw Shale
39.16

9.02

41.87

100.00
81.6

38.6

46.7
53.4

58

6

36

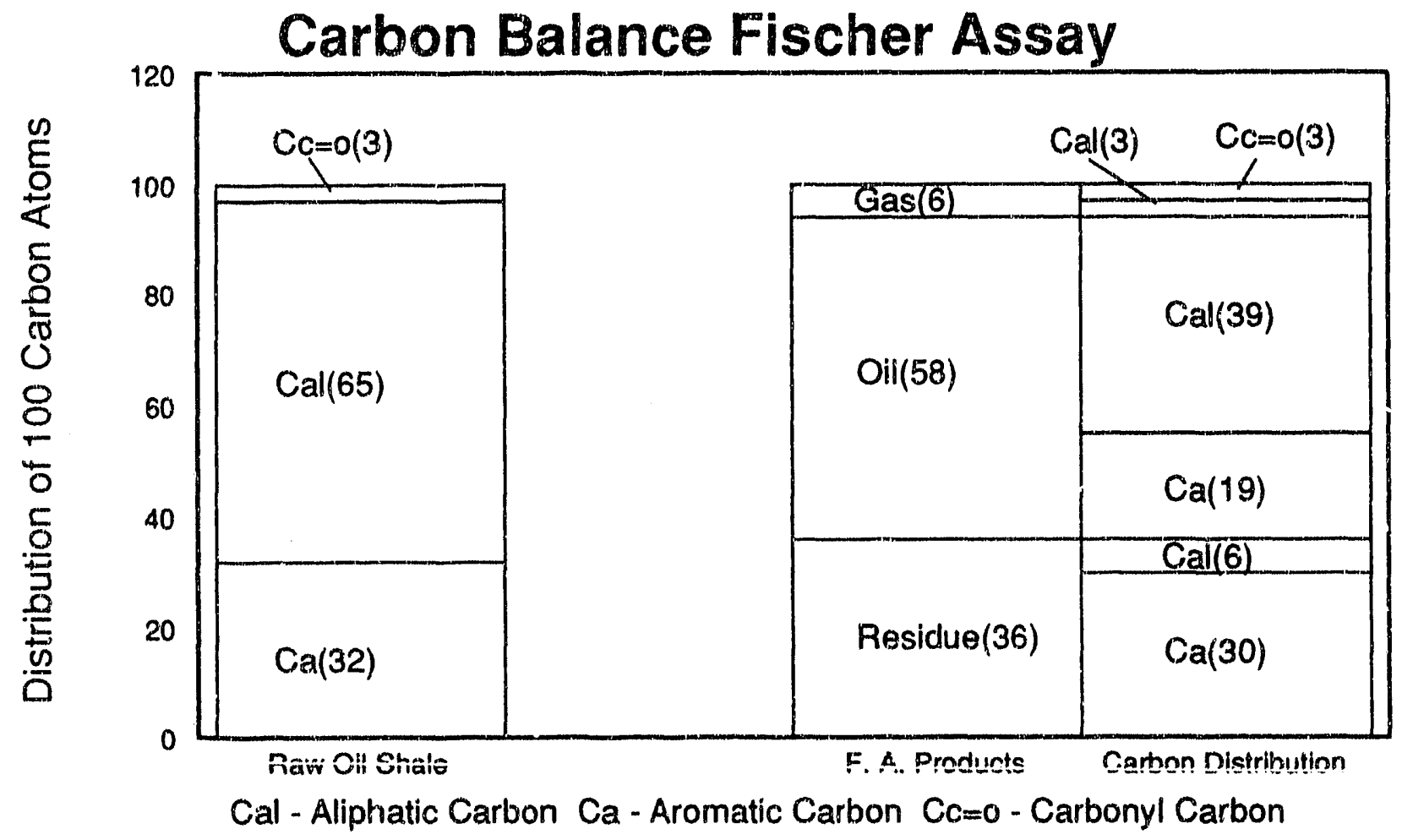




\section{Turkey - Goünük \\ Shale Oil Properties}

$\begin{array}{lrll}\text { Carbon, wt \% } & 81.6 & \text { Carbon Aromaticity, \% } & 33.1 \\ \text { Hydrogen, wt \% } & 11.8 & \text { Hydrogen Aromaticity, \% } & 8.1 \\ \text { Nitrogen, wt \% } & 1.3 & \text { Molecular Weight } & 300 \\ \text { Sulfur, wt \% } & 1.9 & \text { Specific Gravity } & 0.9301\end{array}$

Total H/C $1.74 \quad$ Aromatic H/C 0.425 Aliphatic H/C 2.296

\section{Shale Oil NMR Spectra}

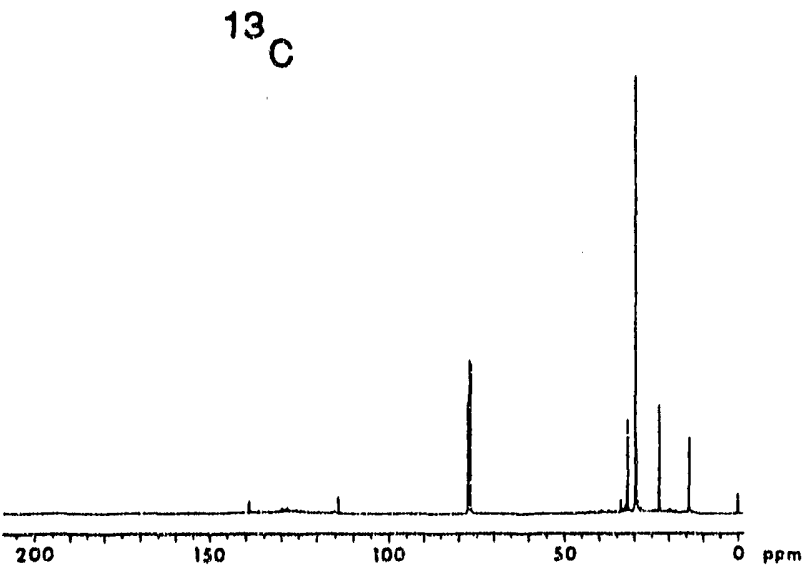

${ }^{1} \mathrm{H}$

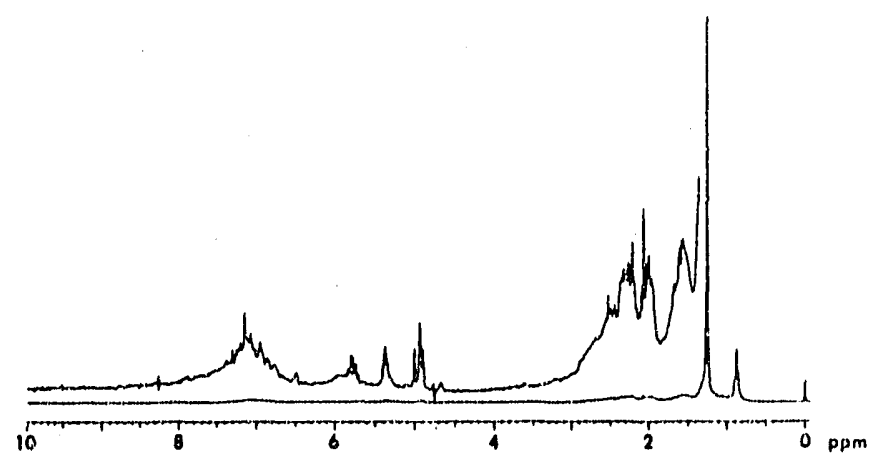

Simulated Distillation of Shale Oil

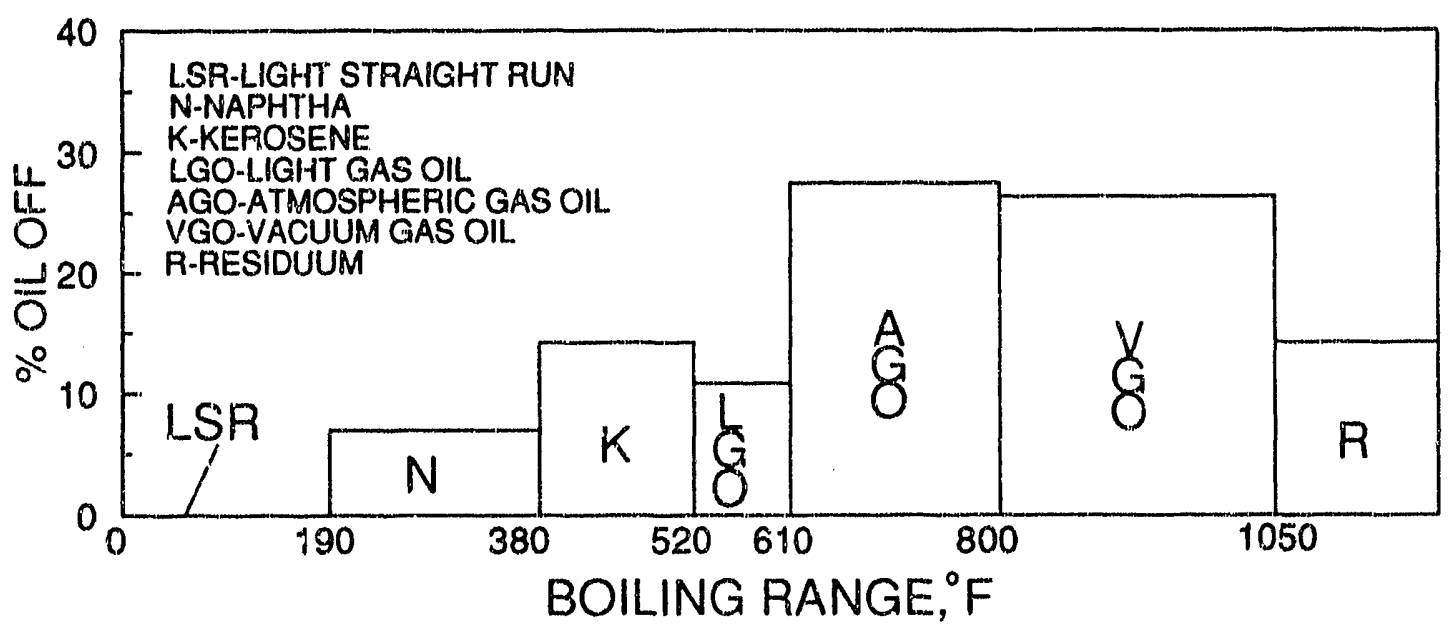


Sample: Seyitomer oil shale

Geologic Age: Unknown

Depositional Environment: Unknown

F. A. Oil Yield: $7.0 \mathrm{gpt}$

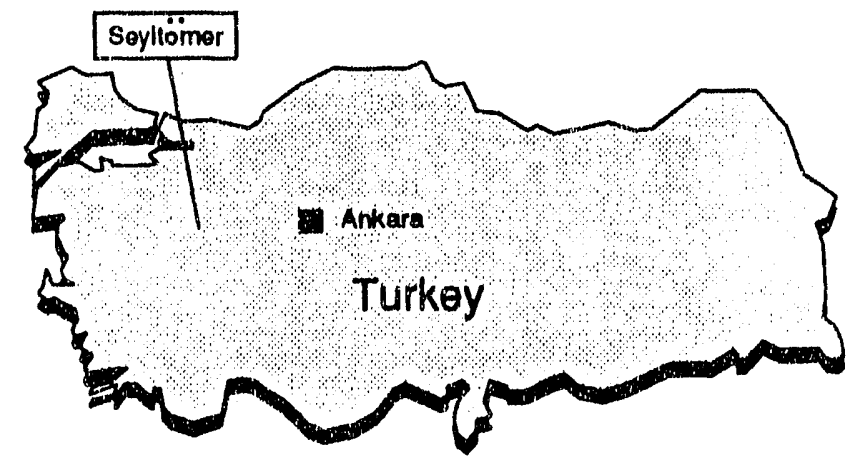

\section{Conversion}

Fischer Assay, wt \% Carbon, wt \% Carbon Conversion, \%

Oil

Gas

Residue

Raw Shale
2.41

1.51

88.67

100.00
85.2

40.3

3.0

5.6
39

11

50

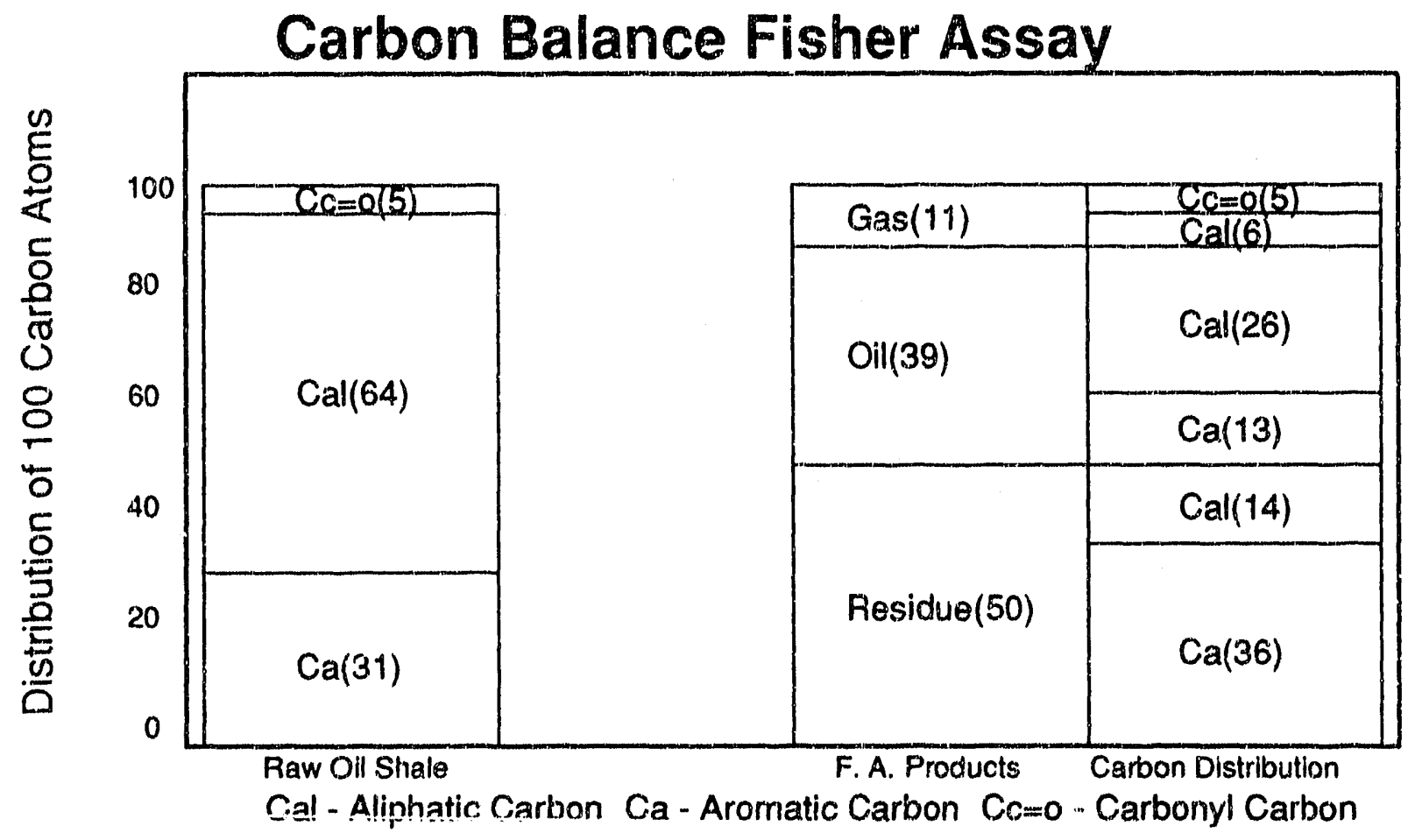




\section{Turkey - Seyitömer Shale Oil Properties}

\begin{tabular}{lr} 
Carbon, wt \% & 85.2 \\
\hline Hydrogen, wt\% & 12.4 \\
Nitrogen, wt \% & 0.9 \\
Sulfur, wt \% & 0.6
\end{tabular}

Carbon Aromaticity, \%

34.6

Hydrogen Aromaticity, \%

9.0

Molecular Weight

280

Sulfur, wt \%

0.6

Specific Gravity

0.8823

Total H/C $\quad 1.75$

Aromatic H/C $0.454 \quad$ Aliphatic H/C

2.345

\section{Shale Oil NMR Spectra}
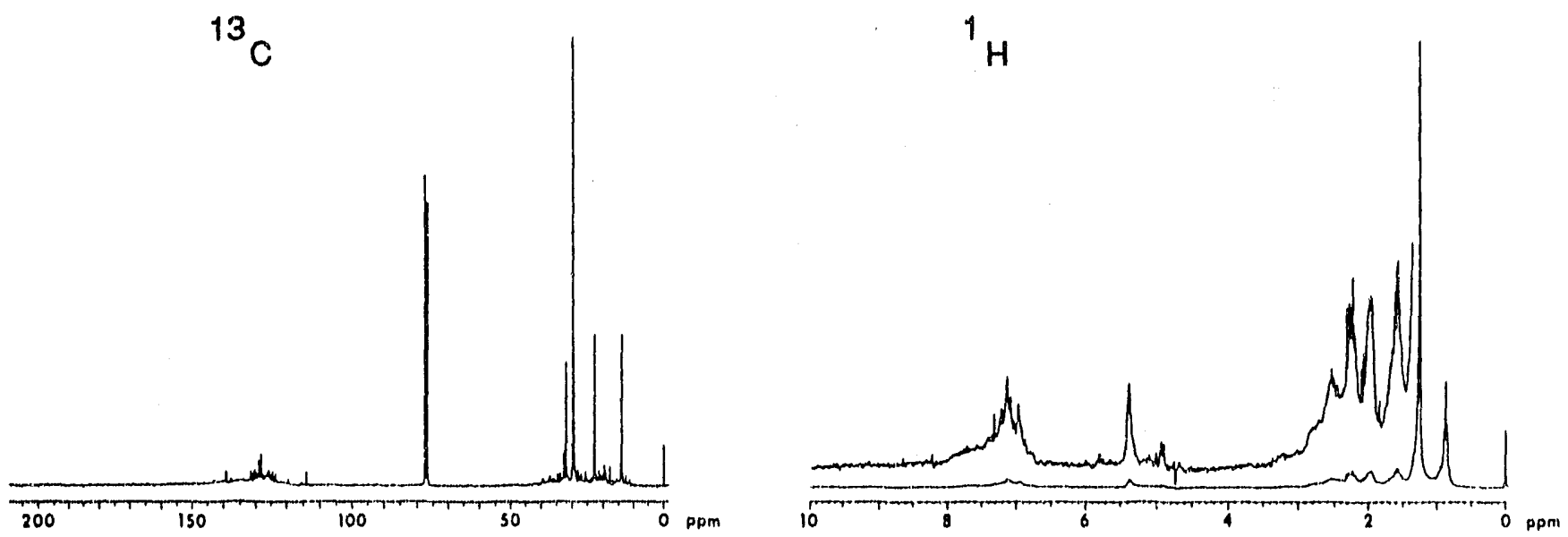

\section{Simulated Distillation of Shale Oil}

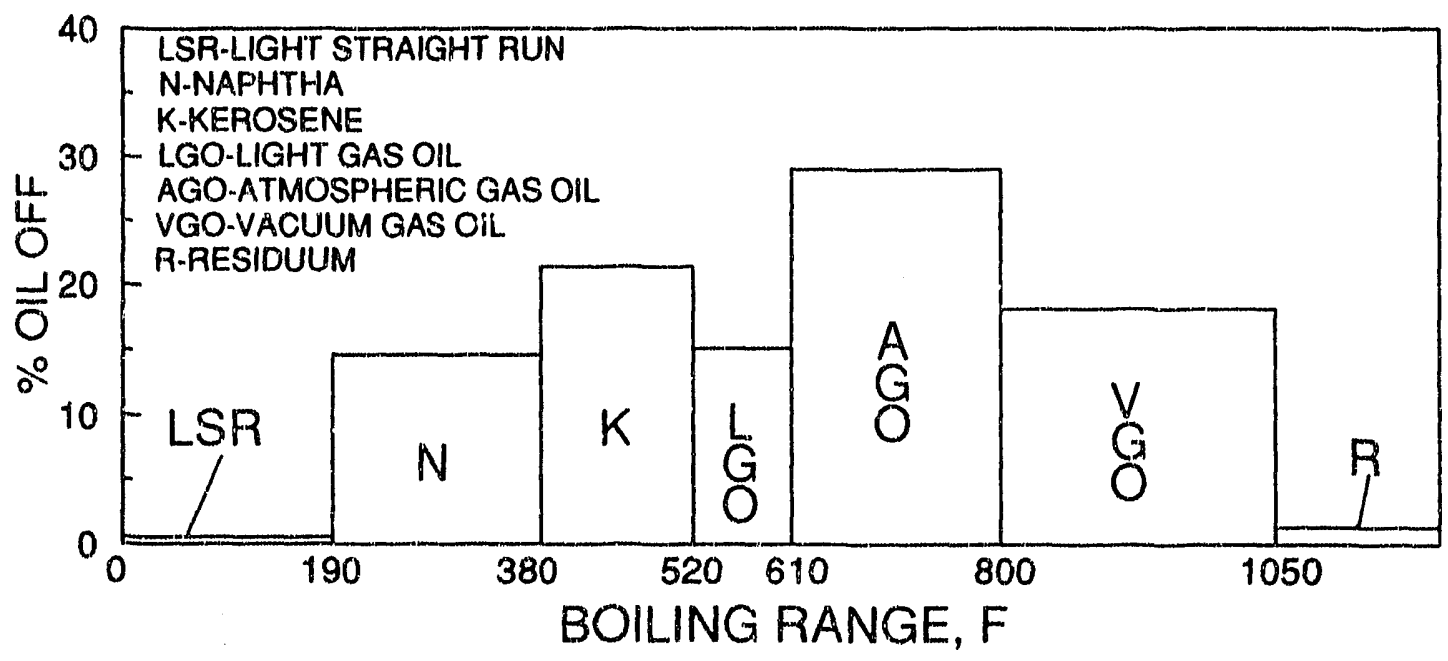



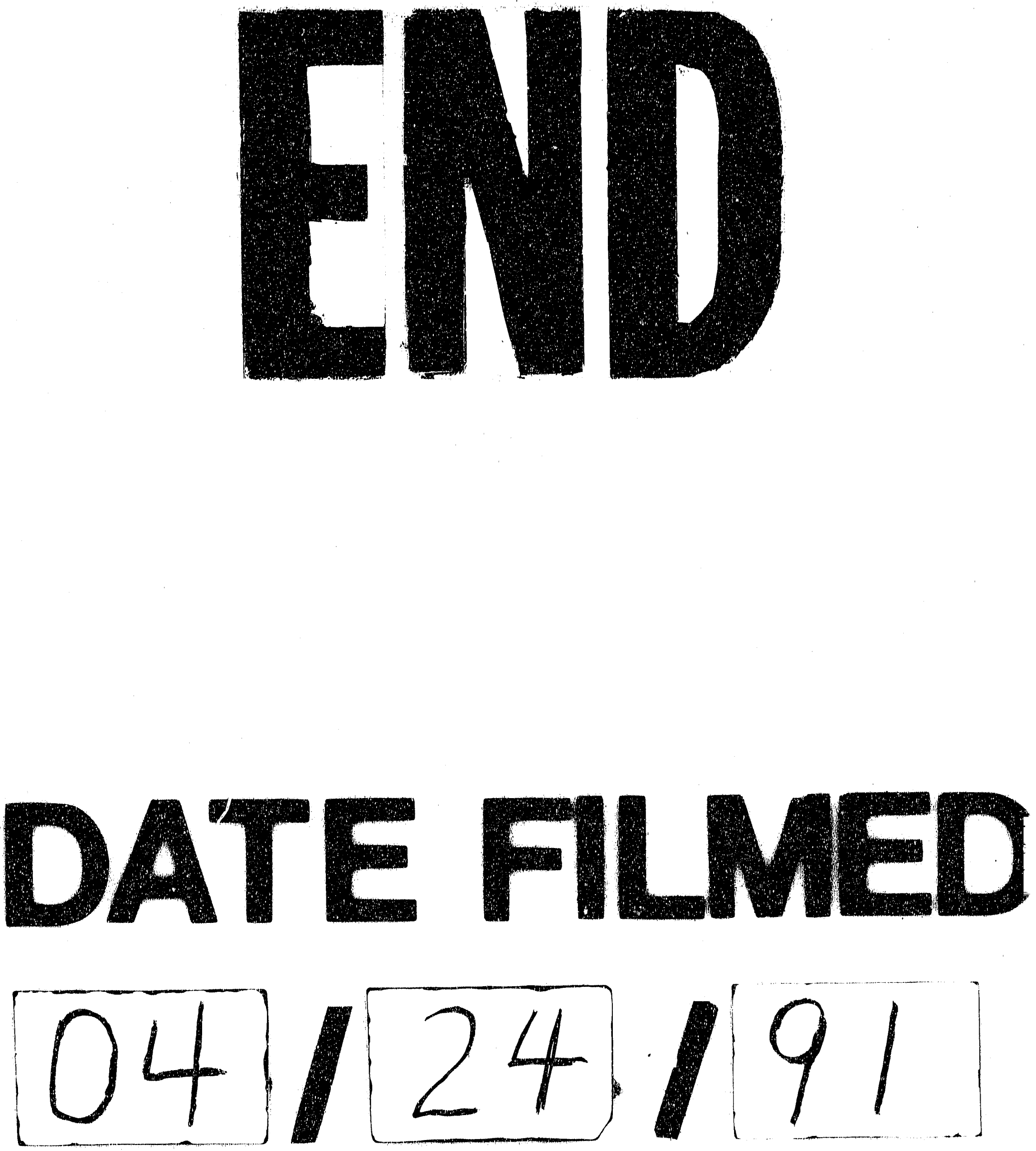
